\title{
Pé preto no barro branco \\ a língua dos negros da Tabatinga
}

\author{
Sônia Queiroz
}

QUEIROZ, S. Pé preto no barro branco: a língua dos negros da Tabatinga [online]. 2nd ed. rev. Belo Horizonte: Editora UFMG, 2018, 149 p. ISBN: 978-85-423-0305-6.

https://doi.org/10.7476/9788542303056.

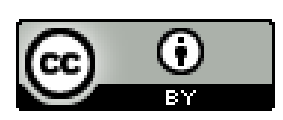

All the contents of this work, except where otherwise noted, is licensed under a Creative Commons Attribution 4.0 International license.

Todo o conteúdo deste trabalho, exceto quando houver ressalva, é publicado sob a licença Creative Commons Atribição 4.0.

Todo el contenido de esta obra, excepto donde se indique lo contrario, está bajo licencia de la licencia Creative Commons Reconocimento 4.0. 
PÉ PRETO NO BARRO BRANCO

a LINGUA DOS NEGROS DA TABATINGA 


\section{UNIVERSIDADE FEDERAL DE MINAS GERAIS \\ REITORA Sandra Regina Goulart Almeida VICE-REITOR Alessandro Fernandes Moreira}

EDITORA UFMG

DIRETOR Flavio Carsalade

VICE-DIRETORA Camila Figueiredo

CONSELHO EDITORIAL

Flavio Carsalade (PRESIDENTE)

Ana Carina Utsch Terra

Antônio de Pinho Marques Júnior

Antônio Luiz Pinho Ribeiro

Camila Figueiredo

Carla Viana Coscarelli

Cássio Eduardo Viana Hissa

César Geraldo Guimarães

Eduardo da Motta e Albuquerque

Élder Antônio Sousa Paiva

Helena Lopes da Silva

João André Alves Lança

João Antônio de Paula

José Luiz Borges Horta

Lira Córdova

Maria Alice de Lima Gomes Nogueira

Maria Cristina Soares de Gouvêa

Renato Alves Ribeiro Neto

Ricardo Hiroshi Caldeira Takahashi

Rodrigo Patto Sá Motta

Sônia Micussi Simões

Tereza Virgínia Ribeiro Barbosa 
SôNIA QUEIROZ

\section{PÉ PRETO NO BARRO BRANCO \\ a LINGGUA DOS NEGPOS DA TABATNGA}

2. edição facsimilar revisada

Belo Horizonte

Editora UFMG

2018 
Este livro ou parte dele não pode ser reproduzido por qualquer meio sem autorização escrita do Editor

Queiroz, Sônia Maria de Melo

Q3p

Pé preto no barro branco [recurso eletrônico]: a língua dos negros da Tabatinga / Sônia Queiroz.

- Belo Horizonte: Editora UFMG, 2018.

1 recurso online: epub.

ISBN: 978-85-423-0269-1

1. Dialetos crioulos portugueses. 2. Negros Brasil. I. Título.

$$
\begin{aligned}
& \text { CDD : } 410 \\
& \text { CDU : } 801
\end{aligned}
$$

Elaborada pela Biblioteca Professor Antônio Luiz Paixão - FAFICH/ UFMG - TEL. 3409-6318

\author{
ASSISTENNCIA EDITORIAL \\ Eliane Sousa \\ DIREITOS AUTORAIS \\ Anne Caroline Silva \\ COORDENAÇÃO DE TEXTOS \\ Lira Córdova \\ REVISÃO DE TEXTOS \\ Olívia Almeida \\ PROJETO GRÁFICO \\ Glória Campos - Mangá \\ MONTAGEM DE CAPA \\ By design \\ FORMATAÇÃO \\ Rômulo Costa Vianna \\ PRODUÇ̃̃O GRÁFICA \\ Warren Marilac
}

\title{
EDITORA UFMG
}

Av. Antônio Carlos, 6627 - CAD II / Bloco III

Campus Pampulha - 31270-901 - Belo Horizonte / MG

Tel: + $55313409-4650$ - Fax $:+55313409-4768$

www.editoraufmg.com.br - editora@ufmg.br 
Agradeço aos falantes da Língua do Negro da Costa, pelas entrevistas concedidas, e à profa. dr. ${ }^{a}$ Ângela Vaz Leão, que acreditou e investiu com dedicação no meu projeto de pesquisa. 
Sara sara sara cura

Dessa doença de branco

De querer cabelo liso

Já tendo cabelo louro

Cabelo duro é preciso

Que é pra ser você crioulo.

GILBERTO GIL - Sarará Miolo 
CAPÍTULO III

BREVES NOTÍCIAS SOBRE A FREGUESIA DE N. S. DO BOM DESPACHO

CAPÍTULO IV NAS CAFUAS DA TABATINGA, UMA LÍNGUA AFRICANA 
$\begin{array}{llllllllllllll}L & \text { I } & \text { S } & \text { T } & \text { A } & \text { D } & \text { E } & \text { F } & \text { I } & G & U & R & A & S\end{array}$

1 - ESBOÇO DO MAPA ETNOLÓGICO

AFRICANO NO BRASIL

2 - NÚCLEOS DE RESISTÊNCIA CULTURAL AFRO-NEGRA EM MINAS GERAIS

3 - FAZENDA DO SAPÉ, PROPRIEDADE

DE PAULO DE TARSO GONTIJO. DETALHE

DA CASA-SEDE, CONSTRUÍDA POR

ESCRAVOS HÁ MAIS DE 150 ANOS

4 - REMANESCENTES DO TRABALHO

ESCRAVO NA FAZENDA DA CACHOEIRA, PROPRIEDADE DOS HERDEIROS DE ANTÔNIO LOPES DO COUTO. DETALHE LATERAL DA CASA-SEDE, CUJAS PAREDES, DE PAU A PIQUE, SE APÓIAM SOBRE UMA BASE DE PEDRA SECA

5 - REMANESCENTES DO TRABALHO ESCRAVO NA FAZENDA DA CACHOEIRA, PROPRIEDADE DOS HERDEIROS DE ANTÔNIO LOPES DO COUTO. ENGENHO DE CANA-DE-AÇÚCAR

6 - DeTAlHe DO ENGENHO: RODA

D'ÁGUA

7 - REMANESCENTES DO TRABALHO ESCRAVO NA FAZENDA DA CACHOEIRA, PROPRIEDADE DOS HERDEIROS DE ANTÔNIO LOPES DO COUTO. MOINHO D'ÁGUA

8 - FESTA DE CONGADO EM BOM DESPACHO. O TERNO DO BAIANO, DA TABATINGA, COMPOSTO SÓ DE NEGROS

9 - IGREJA DO ROSÁRIO EM BOM DESPACHO, DEMOLIDA POR VOLTA DE 1930 
10 - A RUA TABATINGA (À DIREITA)

VISTA DO CRUZAMENTO COM A CRUZ

DO MONTE

11 - A RUA CRUZ DO MONTE (À

ESQUERDA) VISTA DO CRUZAMENTO

COM A TABATINGA

12 - AlTO DA RUA CRUZ DO MONTE,

ANTIGO CAMINHO PARA O CRUZEIRO

13 - TRECHO DA RUA TABATINGA: A

ELETRICIDADE CHEGOU, O ESGOTO

NÃO

55

14 - VISTA EXTERNA DE HABITAÇÕES

DA TABATINGA, EM QUE SE PERCEBE A AUSÊNCIA DE REBOCO NAS PAREDES

15 - VISTA EXTERNA DE HABITAÇÃO DA TABATINGA, COMO AS DA FIGURA 14, SEM REBOCO NAS PAREDES

16 - HABITAÇÃO TÍPICA DA TABATINGA, COM PRIVADA NA PARTE EXTERNA

17 - JESUS E ANGÉLICA, OS ÚLTIMOS DESCENDENTES DE DAGOBERTO TOMÁS PINTO - O DICOBERTO

18 - MARIA FELICIANO - MANTENDO A TRADIÇÃO DA CESTARIA, ARTESANATO BANTO

19 - OS DESCENDENTES DE ZÉ CARIA (OU ZACARIA) - MARIA JOAQUINA DA SILVA, A FIOTINHA (NO ALTO, À ESQUERDA), COM UMA FILHA E NETOS

20 - OS DESCENDENTES DE ZÉ CARIA (OU ZACARIA) - JOSÉ ANTÔNIO DA SILVA, FILHO DA FIOTINHA, E FILHOS

21 - O LIVRO DE VIOLETA: A MÃE PRETA CONTA "CASOS ENGRAÇADOS" AOS MENINOS DO BRASIL 


$\begin{array}{llllllllllllll}\text { L } & \text { I } & \text { S } & \text { T } & \text { A } & \text { D } & \text { E } & \text { T } & \text { A } & \text { B } & \text { E } & \text { L } & \text { A } & \text { S }\end{array}$

1 - REPARTIÇÃO DOS ESCRAVOS AFRICANOS DA VILA DE PITANGUI, SEgUNDO A ORIGEM, NO PERÍODO DE 1718 A 1723

2 - DISTRIBUiÇÃO DOS FALANTES DA

LNC SEGUNDO A COR

3 - DistRIBUiÇÃO DOS FALANTES DA

LNC SEGUNDO O SEXO

4 - DISTRIBUIÇÃO DOS FALANTES DA

LNC SEGUNDO O DOMICÍlIO

5 - DisTRIBUIÇÃO DOS FALANTES DA LNC SEGUNDO O LOCAL DE NASCIMENTO

6 - DISTRIBUIÇÃO DOS FALANTES DA

LNC SEGUNDO A RELIGIÃO

7 - DISTRIBUIÇÃO DOS FALANTES DA

LNC SEGUNDO O ESTADO CIVIL

8 - DISTRIBUIÇÃO DOS FALANTES DA

LNC SEGUNDO A IDADE

9 - DISTRIBUIÇÃO DOS FALANTES DA

LNC SEGUNDO A ESCOLARIDADE

10 - DistribuiÇÃO DOS FALANTES DA

LNC SEGUNDO A PROFISSÃO

11- DistribuiçÃO DOS FALANTES DA

LNC SEGUNDO A RENDA

12 - DisTRIBUIÇÃO DOS FALANTES DA

LNC SEGUNDO A CONDIÇÃO DE OCU-

PAÇÃO DO DOMICÍLIO

13 - Distribuição DOS FALANTES

DA LNC SEGUNDO O TIPO DE

CONSTRUÇÃO DO DOMICÍlIO

14 - DISTRIBUIÇÃO DOS FALANTES DA

LNC SEGUNDO A INFRA-ESTRUTURA

BÁSICA DO DOMICÍLIO 
15 - DisTRIBUIÇÃO DOS FALANTES DA LNC SEGUNDO A PESSOA COM QUEM A APRENDERAM

16 - DISTRIBUIÇÃO DOS FALANTES DA LNC SEGUNDO A IDADE COM QUE A APRENDERAM

17 - DISTRIBUIÇÃO DOS FALANTES DA LNC SEGUNDO AS SITUAÇÕES DE FALA EM QUE PREDOMINANTEMENTE A USAM 


\section{PAPO DE ENGRAXATE}

Meu primeiro contato com a Língua do Negro da Costa se deu ainda na minha infância. Eu vivia em Bom Despacho, onde, como em toda pequena cidade do interior de Minas, tudo gira em torno da igreja matriz. À volta da igreja, os casais passeiam, os políticos conchavam, as crianças brincam, passam os enterros e as procissões, as comadres (e os compadres) comentam. Enfim, tudo acontece e de tudo se toma conhecimento na praça da matriz.

Nessa praça, em Bom Despacho, em frente à porta principal da igreja, havia sempre alguns engraxates que, enquanto lustravam sapatos, conversavam numa língua ininteligível para os não-iniciados e que diziam de origem africana. Eram meninos pobres vindos da Tabatinga ou da Cruz do Monte - ruas da periferia da cidade cujos habitantes sempre foram tidos por marginais. De tanto passar por ali, a gente do centro da cidade acabava por aprender alguma coisa. Viriango 'soldado' e ingura 'dinheiro', significativamente, são as duas palavras que me ficaram na memória, daquela época.

Lembro-me ainda de uma curiosidade relacionada com o caráter de código secreto atribuído à língua por seus falantes. O tio de um amigo meu, passando férias na cidade, interessou-se pela língua dos engraxates e lhes propôs a compra do seu "dicionário". A meninada se reuniu, discutiu o assunto e resolveu que não havia negócio a fazer com o homem. Que se fosse ele com o seu dinheiro. Eles ficariam lá com a língua deles.

Hoje, os engraxates não existem mais à porta da igreja, e parece que a Língua do Negro da Costa, como é chamada por muitos de seus falantes, também tende a desaparecer. Deixá-la morrer sem um registro seria desconhecer ou pelo menos subestimar a importância que tem o estudo de falares como esse para um melhor conhecimento da nossa realidade lingüística e sócio-cultural. Compreendi isso sobretudo a partir das reflexões a que me levaram as leituras feitas em Sociolingüistica, durante meu curso de pós-graduação em Letras. 
Acabei por escolher a Língua do Negro da Costa como tema da minha dissertação de Mestrado, transformando-a, assim, de objeto de memória em objeto de pesquisa.

Sônia Queiroz 


\section{DE OLHO NO NEGRO}

Do choque das culturas lusa e africana resultou uma variedade de situações, um espectro cultural que não é nem podia ser a civilização brasileira que se tornou moda postular ou projetar, alguns de toda boa fé outros simplesmente por intolerância. Este espectro de culturas é talvez a riqueza mais insuspeita do Brasil.

Olabiyi Babalola Yai $^{1}$

Introduzido no Brasil durante mais de três séculos pelo tráfico escravo, por muito tempo o negro africano constituiu, com seus descendentes, alta percentagem da população do País, tendo sido um dos elementos mais ativos na formação da cultura brasileira. Apesar disso, nem sempre mereceu a devida atenção de nossos antropólogos, historiadores, lingüistas, enfim, daqueles que, direta ou indiretamente, se ocupam em definir nossa cultura. Assim, é comum entre nós a mentalidade assimilacionista, que privilegia a tradição européia e relega nossos índios e negros ao plano das simples influências, como se nossa cultura os precedesse, o que, levado às últimas conseqüências, corresponde a dizer que a civilização brasileira é anterior ao próprio descobrimento do Brasil!

Por isso diríamos que é preciso redescobrir o Brasil. Ou, nas palavras de Olabiyi Babalola Yai,

seria preciso, como o exige a bela fórmula de Carlos Drummond de Andrade, "reinventar os nagôs e os latinos"! Reinventar também os tupis, os guaranis, etc. (...) É, por assim dizer, se não uma exigência, uma ambição de renovação cultural pluralista. Ao invés de ser um cadinho de onde sairia uma cultura nacional às custas de perdas, de assimilação, de intolerância e de menosprezos gratuitos, o Brasil poderia dar ao mundo o exemplo de um pluralismo cultural em que os homens são mais eles mesmos quando vivem plenamente suas culturas próprias e são conseqüentemente capazes de melhor conhecer e de viver as dos outros. ${ }^{2}$

${ }^{1}$ YAI. Cultura, p.95.

${ }^{2}$ Ibidem. p.100. 
Exemplo claro da pouca importância atribuída ao negro brasileiro é a absoluta escassez de trabalhos sobre ele até os fins do século XIX, fato observado por quase todos os estudiosos do assunto, sobretudo nos trabalhos que tratam especificamente da história dos estudos africanistas no Brasil.

Somente a partir do final do século XIX, portanto, é que começam a surgir pesquisas sobre o regime jurídico da escravidão, o tráfico negreiro, a procedência étnica, os grupos lingüísticos, os costumes e as religiões dos africanos trazidos para o Brasil. Até então, "com exceção dos artigos e livros que trataram do problema da Abolição, analisando-o, quase sempre, do ponto de vista econômico, ou, algumas vezes, imbuídos de certo idealismo romântico, de caráter sentimental, nada de concreto acerca do negro brasileiro fora (...) escrito". ${ }^{3}$

A Escravidão no Brasil, de Perdigão Malheiro, publicado pela primeira vez em 1867, é um exemplo da emergente preocupação em ver o negro não apenas como máquina econômica, mas sobretudo como objeto de ciência, postura que encontrará em Sílvio Romero outro de seus grandes defensores. É, no entanto, Nina Rodrigues que inaugura os estudos científicos sobre o negro no Brasil.

Já no final do século XIX, o grande estudioso dá início à publicação, na Revista Brasileira, dos resultados de suas primeiras pesquisas sobre o assunto, que abrangem questões históricas, etnográficas, médicas e sociológicas. Entretanto, sua obra máxima, Os Africanos no Brasil, só será publicada em 1933, quase trinta anos após sua morte. Embora limitado às "hipóteses de trabalho" de sua época, dominada pelas teorias evolucionistas, que o levaram a falar de uma "inferioridade antropológica" do negro e de uma "degenerescência" da mestiçagem, idéias inadmissíveis para os nossos dias, Nina Rodrigues tem o grande mérito de, além de inaugurar o enfoque científico da questão do negro no Brasil, ser o "pioneiro na abordagem de fenômenos de cultura e de aculturação ao identificar o caráter 'híbrido' de instituições e costumes, de mitos e crenças, de ritos e liturgias, de linguagem dos negros". ${ }^{4}$

Nessa fase pioneira, destaca-se também Manuel Querino, cuja abordagem o distingue profundamente de Nina Rodrigues: enquanto este considera o negro como um ser inferior, aquele, negro também, empenha-se

3 OLIVEIRA. Cultura, p.111.

${ }^{4}$ AZEVEDO. Cultura, p.122. 
em elevar os seus irmãos de cor à posição que realmente ocuparam na colonização do Brasil. No entender de Waldir Freitas Oliveira, "não foram até hoje escritas palavras mais sensatas e judiciosas acerca do desempenho e da contribuição do negro no curso da História do Brasil que as de Manuel Querino" em "O Colono Preto como Fator da Civilização Brasileira", comunicação apresentada ao VI Congresso Brasileiro de Geografia, reunido em Belo Horizonte, em 1918.

No início do século XX, excetuando-se o aparecimento de Artur Ramos, continuador do trabalho de Nina Rodrigues, nada de muito importante surge na área, e os estudos africanistas só são retomados na década de 30. Em 1934, Gilberto Freyre publica Casa Grande $\varepsilon$ Senzala, dando início, na opinião de Thales de Azevedo, ${ }^{6}$ a uma nova antropologia cultural e a uma nova história social, aberta ao reconhecimento da presença cultural, social e biológica do negro no Brasil. Realizam-se dois congressos afro-brasileiros, o primeiro em Recife, em 1934, e o segundo na Bahia, em 1937. Destacam-se, então, numerosos pesquisadores, entre os quais os brasileiros Edison Carneiro, Renato Mendonça, Dante Laytano, Mário de Andrade, Aidano do Couto Ferraz e os estrangeiros Donald Pierson, Melville J. Herkovits, Roger Bastide e Pierre Verger.

Nas décadas seguintes, com maior ou menor intensidade, continuaram a surgir trabalhos na área, tendo-se desenvolvido sobretudo os estudos sobre as religiões afro-brasileiras, entre os quais se podem citar, por exemplo, os de Roger Bastide e Pierre Verger e, mais recentemente, Yvonne A.Velho. Também se desenvolveram muito os estudos das relações raciais no Brasil, destacando-se as pesquisas de Florestan Fernandes, Oracy Nogueira e Otávio Ianni.

Em 1959, funda-se na Universidade Federal da Bahia o Centro de Estudos Afro-Orientais - $\mathrm{CEAO}$ - , que se torna o mais ativo centro de formação de africanistas no Brasil, tendo montado uma biblioteca especializada, promovido cursos de extensão sobre a história, a geografia, a sociologia e a economia da África e criado um importante intercâmbio de pesquisadores entre o Brasil e a África. Entre as atividades desenvolvidas pelo CEAO, destaca-se ainda um amplo programa de publicações, em que se inclui a criação, em 1965, da revista Afro-Ásia, que, para Waldir Freitas Oliveira, "se tornaria, muito em breve, a mais importante

5 OLIVEIRA. Cultura, p.112.

${ }^{6}$ AZEVEDO. Cultura, p.122. 
publicação periódica sobre assuntos africanos e afro-brasileiros editada na América Latina".

Mais tarde criam-se o Centro de Estudos Africanos, da Universidade de São Paulo, que, entre outras atividades, mantém um programa de pós-graduação e publica a revista África, e o Centro de Estudos Afro-Asiáticos, da Universidade Cândido Mendes, no Rio de Janeiro, que possui uma biblioteca considerada a mais completa em periódicos, conferências e comunicações e edita a revista Estudos Afro-Asiáticos. De criação mais recente, o Centro de Estudos Afro-Brasileiros, da Universidade Federal de Minas Gerais, promoveu em novembro de 1981 o $1^{\circ}$ Encontro Nacional de Centros de Estudos Afro-Brasileiros, que se realizou em Belo Horizonte e teve como um de seus objetivos principais "unir esforços, apoiar e incentivar as iniciativas de estudo e pesquisa que venham a contribuir para despertar a consciência nacional para o papel histórico e atual dos povos africanos e seus descendentes com relação ao Brasil".

Vê-se, portanto, que o desenvolvimento atingido pelos estudos afro-brasileiros não é ainda suficiente para evidenciar o papel real do negro na sociedade brasileira.

No que diz respeito aos estudos lingüísticos, nossa situação é ainda mais precária. Embora eles tenham recebido certo impulso na década de 30 - quando se publicam os livros considerados clássicos no assunto -, pode-se dizer que andamos a pouca distância da época em que Sílvio Romero9 advertia:

(...) vamos levianamente deixando morrer os nossos negros da Costa como inúteis, e iremos deixar a outros o estudo de tantos dialetos africanos, que se falam em nossas senzalas! (...) Apressem-se os especialistas, visto que os pobres moçambiques, benguelas, monjolos, congos, cabindas, caçangues... vão morrendo.

Com efeito, mais de um século depois da extinção do tráfico de escravos negros e, portanto, já mortos todos os nossos africanos, contamos apenas com pouco mais de meia dúzia de livros (ou teses) dedicados ao estudo das línguas africanas no Brasil, não indo muito além disso o número de artigos de periódicos que tratam do assunto.

\footnotetext{
7 OLIVEIRA. Cultura, p.116.

${ }^{8}$ ENCONTRO nacional de centros de estudos afro-brasileiros, 1981. Os grifos são meus.

${ }^{9}$ Citado por RODRIGUES. Os africanos no Brasil, p.16-17.
} 
É importante observar que a grande maioria desses trabalhos se ocupa da influência das línguas africanas no português do Brasil, na tentativa de definir até que ponto os negros foram os responsáveis pela diferenciação lingüística que se verifica entre Portugal e Brasil. Aí se incluem O Elemento Afro-Negro na Lingua Portuguesa e $O$ Negro Brasileiro e Outros Escritos, de Jacques Raimundo, publicados pela primeira vez em 1933 e 1936, respectivamente; A Influência Africana no Português do Brasil, de Renato Mendonça, cuja primeira edição é de 1933; "Os Africanismos no Dialeto Gaúcho", de Dante Laytano, saído na Revista do Instituto Histórico e Geográfico do Rio Grande do Sul, em 1936; de Nelson de Senna, o artigo "Africanismos no Brasil", publicado na Revista de Lingua Portuguesa, em 1921, e o livro Africanos no Brasil, de 1938; O Elemento Negro, de João Ribeiro, saído em 1938, e as "Contribuições Afro-Negras ao Léxico Popular Brasileiro", que Adelino Brandão publica na Revista Brasileira de Folclore, em 1968.

Mais recentemente, destacam-se os trabalhos de Yeda Pessoa de Castro, que, em 1976, na Universidade do Zaire, defende a tese De l'Intégration des Apports Africaines dans les Parlers de Bahia au Brésil. De volta ao Brasil, vem divulgando os resultados de suas pesquisas através de artigos e conferências.

A questão da influência africana no português do Brasil é também tratada em capítulos de obras de caráter mais genérico, dedicadas ao estudo da língua portuguesa ou da presença do negro em nossa cultura.

Quanto aos falares africanos sobreviventes no Brasil - em que normalmente se misturam línguas africanas e o português - , pouca ou quase nenhuma atenção têm merecido da parte de nossos estudiosos. Antônio da Costa Peixoto registra, em manuscritos de 1731 e 1741, a existência de uma língua veicular de base ewê na região de Vila Rica. ${ }^{10}$ Em 1933, Nina Rodrigues, no já citado Os Africanos no Brasil, publica um vocabulário básico de cinco línguas sudanesas - grunce, jeje, hauçá, kamíri e tapa - colhido em Salvador. Rodolfo Garcia, no I ${ }^{\circ}$ Congresso Afro-Brasileiro, realizado em 1934, apresenta um pequeno vocabulário nagô que teria sido colhido em Pernambuco, mas sobre o qual não fornece nenhuma informação precisa. ${ }^{11}$ Em 1938, João Dornas Filho publica na Revista do Arquivo Municipal, um vocabulário quimbundo -

\footnotetext{
${ }^{10}$ O trabalho só foi publicado em 1945, em Lisboa, por iniciativa de Luís Vieira.

${ }^{11}$ Publicado no volume 1 de Estudos afro-brasileiros, editado no Rio de Janeiro, em 1935, pela Ariel. (Cf. GARCIA, Vocabulário nagô).
} 
acompanhado de observações sobre a morfo-sintaxe do "dialeto" colhido em Itaúna, Minas Gerais.

Além desses vocabulários, há o trabalho de Aires da Mata Machado Filho, O Negro e o Garimpo em Minas Gerais, publicado pela primeira vez em 1943, sobre o que ele chama o "dialeto crioulo" de São João da Chapada, município de Diamantina. O material registrado pelo prof. Aires é reexaminado do ponto de vista lingüístico por Maurizio Gnerre, no artigo "O Corpus dos Vissungos de São João da Chapada (MG)". Alguns desses vissungos - cantos entoados pelos negros no trabalho da mineração - foram gravados em 1982 por Clementina de Jesus, Doca e Geraldo Filme, no LP O Canto dos Escravos, da Eldorado.

Os professores Carlos Alberto Vogt, Peter Fry e Maurizio Gnerre, da UNICAMP, desenvolveram também uma pesquisa sobre a língua falada pela comunidade negra do Cafundó, no estado de São Paulo. Seus primeiros resultados estão registrados nos artigos "Cafundó: uma Comunidade Negra que Fala até Hoje uma Língua de Origem Africana", publicado no número 2 da revista Estudos Lingüísticos, em 1978; "Las Lenguas Secretas de Cafundó", saído no número 9 de Punto de Vista, em 1980; e "Mafambura e Caxapura: na Encruzilhada da Identidade", publicado em 1982 no livro Para Inglês Ver: Identidade e Política na Cultura Brasileira. ${ }^{12}$

Tem-se notícia de duas outras pesquisas sobre línguas usadas por comunidades de origem africana em Minas Gerais, embora nada se tenha publicado ainda a respeito de seus resultados. Em 1976, o jornal Estado de Minas divulga que um grupo da Universidade Federal de Juiz de Fora, coordenado pelo prof. Mário Roberto Zágari, vinha estudando uma língua de origem africana falada em Milho Verde, distrito do Serro. Na mesma região, na localidade de nome Chapada do Norte, ainda segundo matéria publicada no Estado de Minas, em abril de 1983, o americano John David Wyatt reuniu material sobre um dialeto banto usado ali como "único meio de comunicação". ${ }^{13}$

Entretanto, segundo observou o prof. Maurizio Gnerre, por ocasião do II Congresso Nacional de Socio- e Etnolingüística, realizado em 1979, em Niterói, não são poucas as ocorrências desses falares mistos no Brasil. A absoluta escassez de publicação sobre esses falares, no

\footnotetext{
${ }^{12}$ Em 1996, Carlos Vogt e Peter Fry publicaram o livro Cafundó: a África no Brasil. Este trabalho não incorpora os resultados divulgados no livro de Vogt e Fry, mas apenas aqueles publicados nos artigos mencionados acima.
}

13 O CAMINHO empoeirado do difícil desenvolvimento do Norte de Minas, 1983. 
entanto, nos leva a crer na inexistência de outras "línguas" africanas entre nós. Embora o campo de pesquisa seja fértil, ainda é pouco explorado.

Considerando-se ainda a escassez de informação referente aos africanos vindos para o Brasil como escravos - já que foi queimada a documentação oficial relativa ao tráfico, em obediência à Circular de 13 de maio de 1892, do Ministério da Fazenda - e a quase inexistência de documentos lingüísticos do período da escravidão, a descoberta e o estudo desses casos de resistência cultural revestem-se de grande importância, na medida em que podem "contribuir de modo positivo para um conhecimento maior da história do negro no Brasil e modificar, conseqüentemente, a visão elitista ou conformada que em grande parte brancos e também negros alimentamos sobre a questão". ${ }^{14}$

${ }^{14}$ VOGT, FRY, GNERRE. Estudos lingüisticos, p.12. 


\section{OS AFRICANOS ESTAOO CHEGANDO}

Né... né compricado? A gente custa a entendê. Se a senhora num oiá nos livros a senhora num acha. O nego é... é demais. Ih!... uma negrada que só a senhora veno. Cada um tem um nome.

Jesus Pinto ${ }^{1}$

Embora não se saiba com exatidão em que época começaram os portugueses a trazer escravos negros para o Brasil, é certo que eles já trabalhavam nos primeiros engenhos de cana-de-açúcar, tendo sido aqui introduzidos muito antes da oficialização do tráfico, que se dá por Alvará de D. João III, a 29 de março de 1549.

Portanto, os africanos começam a chegar ao Brasil ainda no início do século XVI e a partir daí entram, oficial ou extra-oficialmente, em número cada vez maior, até o ano de 1850, quando, em conseqüência da lei imperial de 4 de setembro, que declara extinto o tráfico, começa a diminuir a sua importação.

Mas até que se efetivasse a extinção do tráfico, os negros entravam em números tão elevados que em alguns momentos chegaram a superar de longe a população branca. Em 1798, por exemplo, o censo mostrou uma população de 1.988.000 homens de $\operatorname{cor}^{2}-406.000$ libertos e 1.582.000 escravos - para 1.010 .000 brancos. $^{3}$

Se a introdução de escravos negros no Brasil está intimamente ligada ao desenvolvimento da indústria da cana-de-açúcar, o grande incremento do tráfico que se verifica nos séculos XVIII e XIX é determinado, fundamentalmente, pela descoberta do ouro e dos diamantes na região das Minas Gerais. Com efeito, a possibilidade de lucros maiores e mais rápidos desloca os interesses econômicos da

\footnotetext{
${ }^{1}$ Jesus Pinto é um dos falantes da LNC — Língua do Negro da Costa — entrevistados nesta pesquisa.

${ }^{2}$ Sob a denominação de "homens de cor" incluem-se aqui negros e mestiços negros.

${ }^{3}$ Cf. AZEVEDO. Democracia racial, citado por ELIA. A unidade lingüística do Brasil, p.69.
} 
agricultura para a mineração, provocando a corrida para as minas, que vai desfalcar os engenhos da mão-de-obra escrava.

Com o deslocamento do eixo econômico para o sul, o Rio de Janeiro torna-se o mais importante centro do comércio negreiro: "No século XVIII, o Rio semelha um porto africano. O Valongo, mercado de escravos, tem um jeito de Luanda. É a maior feira de escravos de todo o Brasil, que exporta para São Paulo, Minas, Estado do Rio e Goiás." "É por essa época, mais exatamente em 1763, que a capital da Colônia é transferida de Salvador para o Rio de Janeiro.

Minas é então o grande consumidor desse mercado: "As estimativas mais modestas calculam que durante o século XVIII entraram no Rio de Janeiro e aí foram vendidos mais de 800.000 africanos, dos quais a maioria foi encaminhada para Minas Gerais."

Tão grande afluxo de escravos para as minas vai desequilibrar a já precária economia da Colônia, desfalcando as lavouras de cana-deaçúcar e de tabaco. Pressionada pelos setores agrícolas, a Coroa tenta, então, limitar o número de escravos deslocados para a mineração: através do Alvará de 20 de janeiro de 1701,

foi S.M. servido mandar que dos negros que de Angola fossem ao Rio de Janeiro se tirassem 200 todos os anos, para os paulistas (mineradores) (...) e dos mais negros se não poderia vender a nenhum paulista, e o mesmo se praticaria na Bahia e mais capitanias sob pena de vendedor pagar a valia do negro em dobro, metade para o denunciante e outra para a Fazenda Real. ${ }^{6}$

Entretanto, esse alvará e todas as outras medidas que o seguiram no sentido de limitar ou impedir a entrada de escravos em Minas foram em vão. O comércio clandestino era praticado em larga escala e, segundo Isaías Golgher, sob a proteção das próprias autoridades, ${ }^{7}$ que, mediante suborno, permitiam a entrada ilegal de levas de escravos tão numerosas que "Borba Gato escreveu a D. Fernando Lancastre que precisaria de um exército para

${ }^{4}$ MENDONÇA. A influência africana no português do Brasil, p.39-40.

${ }^{5}$ COARACY. Escravos para as Minas Gerais, p.100.

${ }^{6}$ DOCUMENTOS históricos da Biblioteca Nacional, citado por GOLGHER. Revista Brasileira de Estudos Políticos, p.142.

${ }^{7}$ GOLGHER. Separata da Revista Brasileira de Estudos Politicos, p.147. 
impedir a entrada de contrabando pela estrada da Bahia". ${ }^{8}$ Dessa forma,

em Minas se reuniu, em período relativamente curto, a maior concentração de escravos verificada no país. Cerca de meio milhão de negros foi empregado na mineração do ouro e dos diamantes nos setenta anos em que essa exploração foi considerada economicamente rendosa.?

Já em 1718, segundo informa Nelson de Senna, ${ }^{10}$ a população negra de Minas, composta de 35.991 indivíduos, é superior à população branca. Essa situação parece ter perdurado pelo menos até meados do século XIX, quando se extingue o tráfico: em 1776, numa população total de 319.769 habitantes, 249.105 - 77,90\% - eram negros ou mestiços de negros; nos anos de 1786 a 1805, os escravos constituíam $47,94 \%$ e 46,38\% da população, donde se pode inferir que os indivíduos de cor continuavam sendo maioria, pois, por essa época, muitos deles já eram alforriados; ${ }^{11}$ em 1821, há 383.061 negros e mestiços de negros, num total de 514.108 habitantes, o que equivale a $74,51 \%$ da população; ${ }^{12}$ mas em 1872, passados aproximadamente vinte anos da extinção do tráfico, os escravos se reduzem a 16,99\% da população de Minas. ${ }^{13}$

Entretanto, se o número de escravos vai-se reduzindo de modo assim tão significativo, até que a lei de 13 de maio de 1888 extingue o regime escravocrata de todo o território brasileiro, os negros e seus descendentes continuam constituindo um alto percentual da população mineira. Assim é que no primeiro recenseamento demográfico da República, realizado em 1890, eles são ainda 53,32\% dos habitantes de Minas Gerais. ${ }^{14}$

Quanto à determinação das origens dos africanos trazidos ao Brasil pelo tráfico, como quase tudo que se refere ao negro no País, não é tarefa simples. Aqui, a dificuldade deve-se não só à escassez de

${ }^{8}$ GOLGHER. Separata da Revista Brasileira de Estudos Políticos, p.149-150.

${ }^{9}$ CARNEIRO. Separata do Boletim do Centro Brasileiro de Pesquisas Educacionais, p.3.

${ }^{10}$ SENNA. Revista de Lingua Portuguesa, p.139.

${ }^{11}$ Cf. SENNA. Africanos no Brasil, p.58-59.

${ }^{12}$ Cf. ESCHWEGE, citado por BARBOSA. Negros e quilombos em Minas Gerais, p.126.

${ }^{13}$ Cf. SENNA. Africanos no Brasil, p.60.

${ }^{14}$ Idem. 
documentos históricos, a que já foi feita referência neste trabalho, mas também ao fato de ter a escravidão unificado os povos africanos, de modo a se perder, com relação a eles, a noção de grupos étnicos. A esse respeito, escreve Artur Ramos:

Desde os tempos coloniais até os nossos dias, houve designações populares de Nagô, Mina, Angola, Moçambique... o que indicava vagamente os pontos do continente africano de onde provieram os negros. Mais comuns eram as designações gerais: 'peça da Índia', 'preto da Guiné', 'negro da Costa'. Para o senhor branco, não havia povos negros diversos, mas apenas o negro escravo. ${ }^{15}$

Em conseqüência dessas dificuldades, os estudiosos do negro no Brasil muitas vezes incorreram em generalizações ou particularizações deformadoras da realidade. Assim é que Spix e Martius, por exemplo, em Viagem pelo Brasil, ${ }^{16}$ descrevem a população negra brasileira como sendo composta exclusivamente de bantos. E, mais tarde, Nina Rodrigues $^{17}$ — embora tendo concentrado suas pesquisas na cidade de Salvador - concluirá pela quase exclusividade de sudaneses, mais especificamente iorubas, em todo o estado baiano.

Para Yeda Pessoa de Castro, é a partir daí que se começa a dividir o País em duas áreas estanques de influência africana, divisão que ela critica sistematicamente e contra a qual buscará evidências em suas pesquisas:

(...) a literatura especializada que se seguiu, com raras exceções, fundamentada na observação dos mesmos candomblés estudados por Nina Rodrigues, terminou por consagrar a divisão do Brasil em duas supostas áreas de influências africanas - iorubas na Bahia e bantos em outros estados - como se essas duas áreas estivessem colocadas em dois compartimentos limítrofes, mas estanques entre si (...). ${ }^{18}$

Dedicando-se à pesquisa etnolingüística, Yeda Pessoa de Castro estende suas investigações para além dos limites urbanos da capital baiana, com o objetivo de, através da determinação dos étimos

\footnotetext{
${ }^{15}$ RAMOS. As culturas negras no novo mundo, p.183.

${ }^{16}$ Citado por LUNA, COSTA. O Estado de S.Paulo, p.6.

${ }^{17}$ RODRIGUES. Os africanos no Brasil, 1976.

${ }^{18}$ CASTRO. Os falares africanos na interação social dos primeiros séculos, p.5.
} 
prováveis ou precisos dos empréstimos lexicais africanos ao português do Brasil, identificar seus falantes originais e situar suas influências no País.

Tão importante para suprir as deficiências da informação histórica, esse estudo das evidências lingüísticas, em seu estágio atual, denuncia a predominância, no Brasil, de "povos procedentes de duas regiões subsaarianas: a região do Oeste africano, ao norte da linha do Equador, e o dominio banto, na extensão sul da linha do Equador". ${ }^{19}$

No Oeste africano localizam-se as culturas tradicionalmente chamadas sudanesas em que se destacam, em nossa formação etnolingüística, o ioruba (ou nagô) e o jeje (ou mina). Ao Sul do Equador estende-se o domínio das culturas bantas, que compreende diversas línguas, originárias do mesmo proto-banto, ${ }^{20}$ das quais se destacam o quicongo, o quimbundo e umbundo como as mais atuantes no Brasil.

As pesquisas realizadas por Yeda Pessoa de Castro, além de determinar os povos e línguas africanas de maior atuação entre nós, permitiram-lhe traçar um "Esboço do Mapa Etnolingüístico Africano no Brasil", ${ }^{21}$ que reproduzimos na Figura 1.

No que diz respeito especificamente a Minas Gerais, há ainda outras evidências de que este não foi um território ocupado exclusivamente ou quase exclusivamente por povos bantos, mas, ao contrário, "grosso modo, pode-se afirmar que houve igualdade no peso relativo dos dois grandes grupos". ${ }^{22}$

Os sudaneses, e em especial os chamados "minas", que possuíam conhecimentos técnicos de mineração, adquiridos já na África, eram até mesmo preferidos pelos mineiros à época da exploração do ouro e dos diamantes. Eis o que escreve a respeito, em 1725, o Governador da Capitania do Rio de Janeiro:

\footnotetext{
${ }^{19}$ CASTRO. Os falares africanos na interação social dos primeiros séculos, p.11.

${ }^{20}$ O termo banto (de bantu, plural de muntu 'homem'), presente em quase todas as línguas desse grupo, foi usado pela primeira vez por Bleek, em 1870. Cf. CASTRO. Ensaios/Pesquisas, p.1.

${ }^{21}$ CASTRO. Ensaios/Pesquisas, p.9.

${ }^{22}$ LUNA, COSTA. O Estado de S.Paulo, p.7.
} 
As Minas é certo que se não podem cultivar senão com negros. (...) os negros minas são os de maior reputação para aquele trabalho, dizendo os mineiros que são os mais fortes, e vigorosos, mas eu entendo que adquiriram aquela reputação por serem tidos por feiticeiros, e têm introduzido o diabo, que só eles descobrem ouro, e pela mesma causa não há mineiro que se possa viver sem nem uma negra mina, dizendo que só com elas tem fortuna. ${ }^{23}$

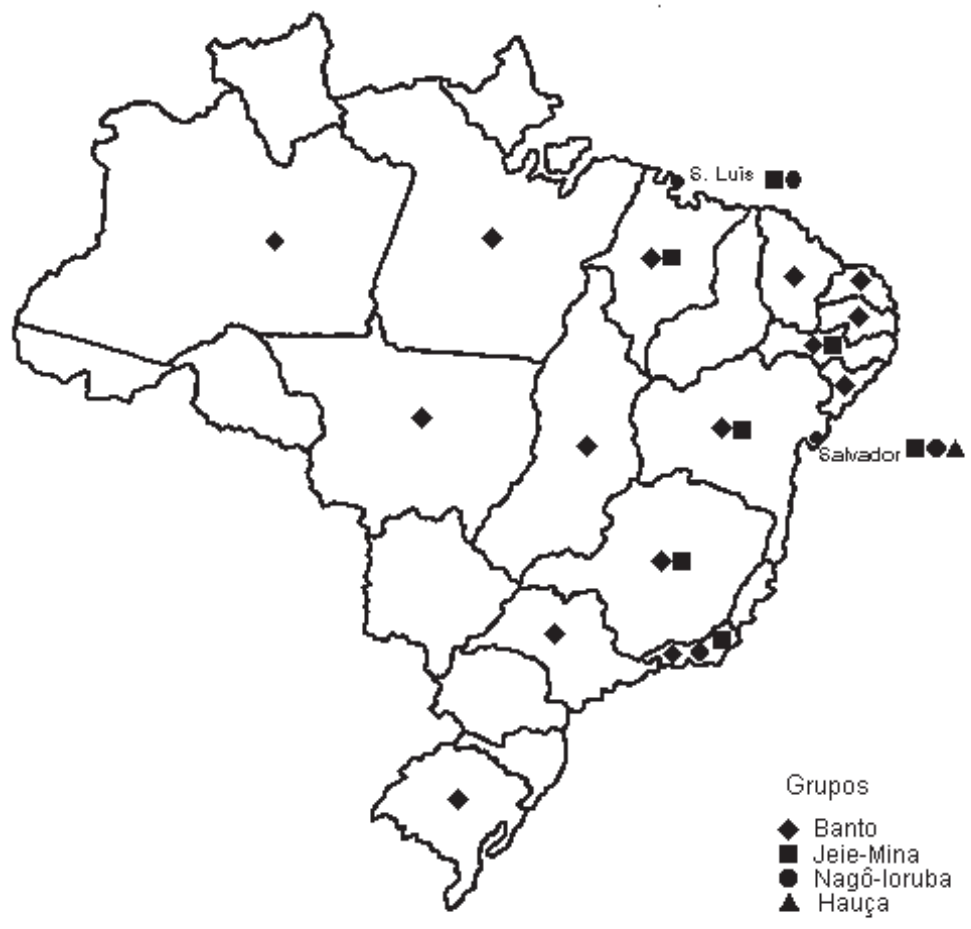

FIGURA 1 - Esboço do mapa etnológico africano no Brasil.

FONTE: CASTRO. A presença cultural negro-africana no Brasil: mito e realidade, p.9.

${ }^{23}$ Citado por LUNA, COSTA. O Estado de S.Paulo, p.6. 
Essa preferência pelos sudaneses - e em particular pelos "minas" - também se reflete em diversos outros documentos do período mineratório, segundo informam Francisco Vidal Luna e Iraci del Nero da Costa em seu artigo "A Presença do Elemento Sudanês nas Minas Gerais". ${ }^{24}$ Entretanto, enquanto no auge da exploração do ouro parece ter havido preponderância dos sudaneses, à época da decadência passam a dominar os bantos. Assim, ambos os grupos parecem ter tido ampla participação na população escrava de Minas Gerais, e

a predominância de um ou outro grupo condicionou-se pelo evolver da atividade mineratória e pelas mudanças na oferta de escravos, sobretudo as relativas às condições imperantes nas áreas africanas fornecedoras desta mão-deobra. $^{25}$

A expressão da Costa, presente na denominação da língua dos negros da Tabatinga, costuma ser associada à Costa dos Escravos, região africana que corresponde ao Benin e à Nigéria atuais, habitada por negros do grupo sudanês. Nina Rodrigues faz referência explícita ao termo lingua da Costa, afirmando que na Bahia designava invariavelmente o nagô, língua sudanesa. ${ }^{26} \mathrm{O}$ fato de ter a mineração intensificado o tráfico de escravos negros provenientes da Costa da Mina, no Golfo de Benin, e as ligações históricas de Bom Despacho com uma vila do ouro, Pitangui, sugerem mais uma vez uma origem sudanesa para a língua chamada "do negro da costa".

Entretanto, os dados lingüísticos colhidos em gravações na Tabatinga, em Bom Despacho, indicam para ela, ao contrário, uma origem predominantemente banto. Por isso entendemos, com Artur Ramos, que a expressão negro da Costa é, antes, uma denominação genérica, utilizada inicialmente pelos senhores brancos para se referir aos negros escravos sem distinguir-lhes as origens africanas. ${ }^{27}$ Lingua do Negro da Costa significaria, portanto, "língua de africano", o que parece se confirmar por outros nomes que ela recebe de seus falantes, em Bom Despacho: gíria dos cativero e língua do cuete (lit. 'língua do homem').

\footnotetext{
${ }^{24}$ LUNA, COSTA. O Estado de S.Paulo, p.6.

${ }^{25}$ Ibidem. p.7.

${ }^{26}$ RODRIGUES. Os africanos no Brasil, p.183.

${ }^{27}$ RAMOS. As culturas negras no novo mundo, p.183.
} 
Uma fonte importante para a determinação dos grupos de africanos que se concentravam nas diversas regiões do País são seus remanescentes culturais, tais como os cultos religiosos, o artesanato, a dança, a língua. No caso específico de Minas, constituem farto material para pesquisa as comunidades negras isoladas, formadas, em geral, a partir de quilombos ou em conseqüência da segregação racial imposta pelo Governo Régio, que, temeroso do elevado número de negros e mulatos aqui existentes no século XVIII, chegou a

obrigar os pretos e mestiços forros ou libertos a habitarem bairros separados do convívio dos brancos. Daí, o fato de ainda se conhecerem pelo nome de 'Arraial-dos-Forros' certos subúrbios do antigo Tejuco (Diamantina), Serro, Ouro Preto, Sabará, Paracatu, etc. ${ }^{28}$

Em artigo publicado em 1938, ${ }^{29}$ João Dornas Filho dá notícia de mais uma localidade em que se verifica o fenômeno da resistência cultural africana em Minas: o povoado de Catumba, no município de Itaúna. Considerado por ele ruínas de um quilombo, o vilarejo era, à época em que foi escrito o artigo, habitado unicamente por negros que, vivendo completamente isolados, falavam entre si um dialeto proveniente do quimbundo.

O prof. Aires da Mata Machado Filho, também na década de 30, recolheu em São João da Chapada letra e melodia de 65 cantigas entoadas pelos negros no trabalho da mineração. Os vissungos, como são chamados esses cantos, "distribuem-se em três grupos: o primeiro constituído de peças em puro ambundo; o segundo, mais numeroso, com palavras nativas dos africanos, misturadas com vocábulos vernáculos; o terceiro em puro português do Brasil". ${ }^{30}$ Ao lado desses cantos, os negros sanjoanenses conservaram uma "língua d'Angola" ou "banguela" - como eles próprios a nomeiam —, que vem a ser uma mistura de ambundo e português, incluindo também alguns termos nagôs. ${ }^{31}$

Segundo o prof. Aires, a nove quilômetros de São João da Chapada, há Quartel do Indaiá, lugarejo que, por ocasião da pesquisa,

\footnotetext{
${ }^{28}$ SENNA. Revista de Lingua Portuguesa, p.141.

${ }^{29}$ DORNAS FILHO. Revista do Arquivo Municipal, p.143-150.

${ }^{30}$ MACHADO FILHO. O negro e o garimpo em Minas Gerais, p.107.

${ }^{31}$ Idem.
} 
era habitado quase exclusivamente por negros, que conservavam tradições bantos, como as cafuas - moradias feitas de barro e cobertas de capim ou palmas de coqueiro - e a fabricação de balaios, esteiras e peneiras. ${ }^{32}$ Ainda o mesmo pesquisador dá notícias de um lugarejo próximo a Pitangui, de nome Capivara, cuja população viveu segregada até as primeiras décadas deste século, apresentando peculiaridades dignas de estudo. ${ }^{33}$

Entre essas comunidades que, isoladas em maior ou menor grau, até hoje conservam tradições africanas, merece atenção, ainda, a dos Arturos, grupo familiar que vive em Contagem, trabalhando em agricultura e pecuária para a sobrevivência e liderando as festas de Congado na região. Também em Uberlândia, segundo informou a profa. Norma Smith, da Universidade Federal de Uberlândia, no $1^{\circ}$ Encontro Nacional de Centro de Estudos Afro-Brasileiros, ${ }^{34}$ vive isolado na periferia um grupo de negros que se diz de origem moçambicana. Dos seus ascendentes, preserva não só um vocabulário, como também documentação escrita, passada de geração a geração.

Os negros de Milho Verde, povoado do município do Serro incrustado nas serras do Norte mineiro, vivem em choupanas e até hoje utilizam a economia de troca e também um léxico de origem africana. ${ }^{35}$ Afirma-se que em Capela Nova há uma comunidade com características semelhantes. ${ }^{36}$

Dos quase 300 habitantes de Chapada do Norte, descendentes de escravos fugidos que ali fundaram um quilombo, "poucos falam português fluente. A maioria usa o único meio de comunicação que conhece e transfere de geração a geração: um dialeto banto". ${ }^{37}$ Patrocínio é outro caso de preservação do léxico de origem africana em Minas. ${ }^{38}$

\footnotetext{
${ }^{32}$ MACHADO FILHO. O negro e o garimpo em Minas Gerais, p.50-52.

${ }^{33}$ Ibidem. p. 52.

${ }^{34}$ Promovido pelo Centro de Estudos Afro-Brasileiros da UFMG, e realizado em Belo Horizonte, de 11 a 13 de novembro de 1981.

${ }^{35}$ CIENTISTAS da UFJF descobrem uma tribo de africanos perto do Serro, 1976.

${ }^{36} \mathrm{Idem}$.

${ }^{37}$ O CAMINHO empoeirado do difícil desenvolvimento do Norte de Minas, 1983.

${ }^{38}$ Em 1996, no livro Cafundó: a África no Brasil, Carlos Vogt e Peter Fry dedicam grande parte do capítulo sobre outras "línguas africanas" à "calunga" de Patrocínio (cf. p.234-255). Dois anos antes, o jornalista Gastão Batinga tinha publicado, em edição do autor, o livro Aspectos da presença do negro no Triângulo Mineiro/Alto Paranaíba: Kalunga. Em 2005 Steven E. Byrd apresentou a tese de doutorado Calunga, an Afro-Brazilian Speech of the Triângulo Mineiro: Its Grammar and History, publicada em livro pouco depois.
} 
Somados ao caso da Tabatinga, em Bom Despacho, são, pois, pelo menos dez núcleos de resistência cultural afro-negra já localizados em Minas Gerais, muitos deles ainda por estudar (Figura 2).

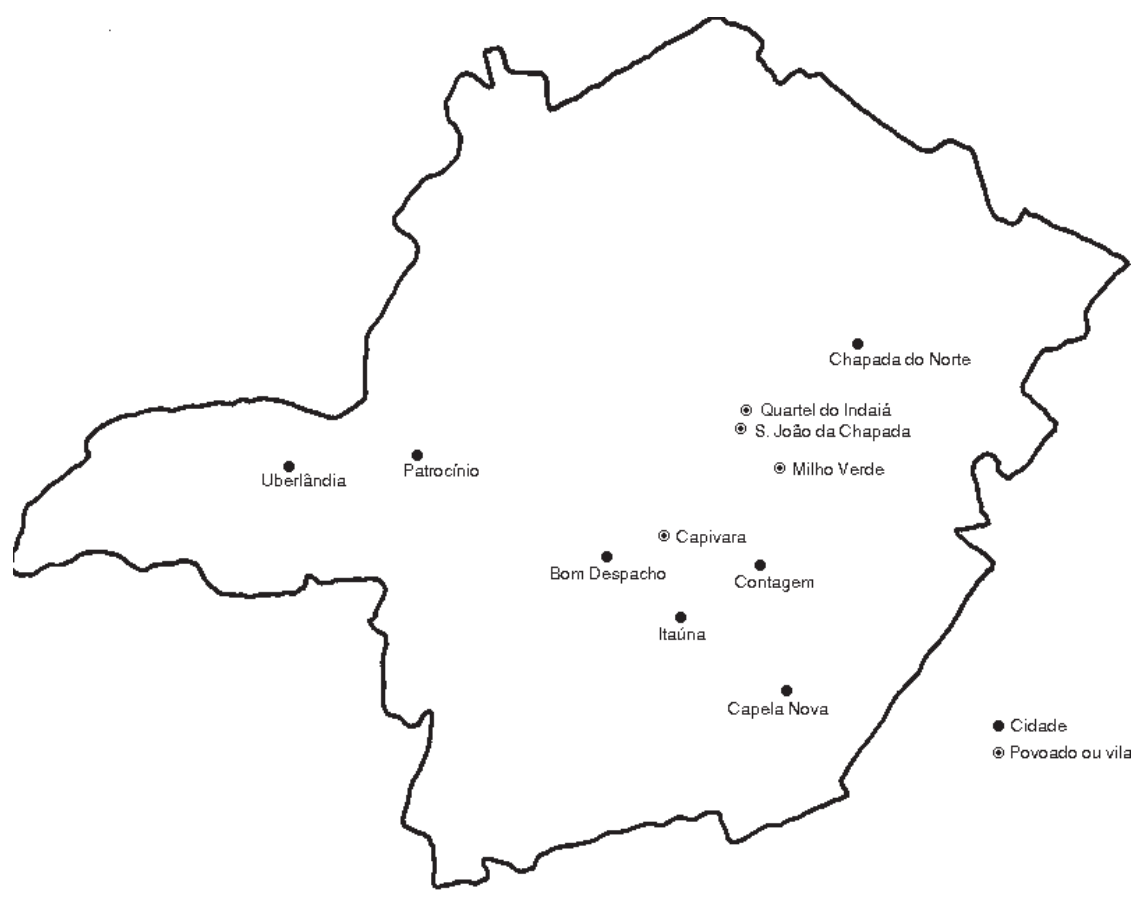

FIGURA 2 - Núcleos de resistência cultural afro-negra em Minas Gerais. 


\section{BREVES NOTCCASS SOBRE A RREGUESIA DE N. S. DO BOM DESPACHO}

O fazendeiro mais rico do município de Pitangui pertence àquela Freguesia (de Bom Despacho); e ali, fazendeiros de 10, 15 e 20 escravos são encontrados de légua em légua.

Gustavo Xavier Capanema

Situado na Zona Oeste de Minas Gerais, entre os rios São Francisco e Lambari, o município de Bom Despacho dista $140 \mathrm{Km}$ em linha reta da capital do Estado, à qual se liga pela BR-262. A população, que em 1970 era de 27.298 habitantes, dedica-se sobretudo à agropecuária. Os principais produtos agrícolas são o milho e o arroz, e os principais rebanhos, o bovino e o suíno. A indústria extrativa também contribui para a economia municipal, produzindo cristal de rocha, lenha, dormentes e cascas taníferas. ${ }^{2}$

Embora tenha sido elevada à categoria de município e vila somente neste século, a 30 de agosto de 1911, Bom Despacho possui uma história que começa por volta da metade do século XVIII e se liga intimamente a Pitangui, uma das primeiras vilas do ouro, à qual pertenceu até o ano de $1880 .^{3}$

Segundo a tradição registrada pelo Pe. Nicolau Ângelo del Duca em 1886 no Livro do Tombo da Paróquia, ${ }^{4}$ o povoamento da região de Bom Despacho tem início com a chegada de quatro portugueses:

\footnotetext{
${ }^{1}$ Discurso proferido na Assembléia Provincial, em 8/7/1872. Citado por RODRIGUES. História de Bom Despacho, p.98.

${ }^{2}$ Cf. IBGE. Município de Bom Despacho, 1978. FERREIRA. Enciclopédia dos municípios brasileiros, p.205-208.

${ }^{3}$ Cf. RODRIGUES. História de Bom Despacho, p.103.

${ }^{4}$ Ibidem. p.109-111.
} 
Manoel Picão Camacho, Domingos Luiz de Oliveira, Manoel Ribeiro da Silva e o Pe. José Hermenegildo Vilaça. O primeiro, genro do célebre "Velho da Taipa", 5 teria chegado ali por volta de 1730. Os outros três, deportados por Pombal, em 1775 aproximadamente.

As fazendas de dois deles, Domingos Luiz de Oliveira e Manoel Ribeiro da Silva, "eram contíguas, ficando intermediário, eqüidistante e divisório entre elas um lugar (...) formado por três colinas unidas (...), e aí haviam eles fincado seus marcos de divisa (...)" ${ }^{6}$ E aí também é que eles se encontravam "a miúde, por ocasião de suas caçadas".

Ainda segundo o Pe. del Duca, "foi esta a localidade que Domingos Luiz de Oliveira e Manoel Ribeiro da Silva escolheram e designaram para o estabelecimento de uma aldeia, cuja iniciativa deram pela ereção de uma pequena ermida, que ficou coberta de capim (...)". ${ }^{8}$ O nome da capela ficou sendo Nossa Senhora do Bom Despacho do Picão, numa dupla homenagem: à virgem do Bom Despacho a quem pediam a proteção da aldeia e o perdão do rei português, para que pudessem voltar a seu país - e a Picão Camacho, o primeiro homem a fixar residência naquelas paragens.

A essa versão, fundada na tradição oral, o prof. Laércio Rodrigues, depois de vasculhar arquivos de cartórios e igrejas, opõe a sua História de Bom Despacho, ${ }^{9}$ que começa não com casos de caçadas de veados e pedidos de indulto, mas com o fim do sonho do ouro e das pedras preciosas em Minas Gerais.

Ocorre que no início da segunda metade do século XVIII as minas de Pitangui já não produzem quase nada. É então que a vila passa a exercer "poderosa influência na marcha povoadora e no movimento da colonização da vasta zona mineira então submetida à sua jurisdição espiritual e temporal". ${ }^{10}$ Dali saíram mineradores e também aqueles que viviam indiretamente da garimpagem, à cata de novos meios de sobrevivência. Tem início, assim, a "corrida

\footnotetext{
${ }^{5}$ Antônio José Velho, paulista que se estabeleceu em Pitangui na primeira metade do século XVIII, tornando-se famoso pelo despotismo no trato com seus subordinados.

${ }^{6}$ RODRIGUES. História de Bom Despacho, p.110.

7 Idem.

${ }^{8}$ Idem.

9 Ibidem. p.98.

${ }^{10}$ Ibidem. p.9.
} 
para os sertões", em busca de terras adequadas à lavoura e à criação de gado.

Nessa nova fase da economia de Minas Gerais, é importante o papel desempenhado pelas estradas que vão sendo abertas sertão adentro. No que respeita à região entre o Lambari e o São Francisco, é de grande importância a Picada Pitangui-Piraquara-Paracatu, "que, cortando, no sentido leste-oeste, todo o território do atual Município de Bom Despacho, contribuiu para o seu povoamento, figurando Pitangui como o principal núcleo da expansão colonizadora". ${ }^{11}$

Dessa forma, no período compreendido entre os anos de 1755 e 1800, dezenas de pessoas, vindas sobretudo de Pitangui, dirigem-se para a região da atual Bom Despacho. Em 1765, segundo consta dos "Autos Incompletos de Medição da Sesmaria de Antônio Rodrigues da Rocha", "já se contavam ali nada menos de 24 'fogos' ou casas, cujos habitantes se dedicavam à criação de porcos, de gado bovino e cavalar. A atividade agrícola era secundária e só lavravam a terra esses pioneiros na medida exigida pelo consumo". ${ }^{12}$

Quanto à primitiva capela coberta de capim, de acordo com documento encontrado por Laércio Rodrigues, ${ }^{13}$ foi fundada por Luís Ribeiro da Silva, ${ }^{14}$ "que lhe instituiu patrimônio em terras de sua fazenda, por escritura homologada por sentença de 26 de junho de 1767". ${ }^{15}$ O mesmo Luís Ribeiro da Silva "requereu e obteve sua primeira provisão canônica, passada em data de 16 de novembro de 1771 "16 e no ano seguinte a capela ganhava já seu primeiro capelão. Portanto, a fundação do povoado - que para o Pe. del Duca só se dá depois de 1775 - fica antecipada, no entender de Laércio Rodrigues, para o ano de $1770 .{ }^{17}$

${ }^{11}$ RODRIGUES. História de Bom Despacho, p.24.

12 Ibidem. p.26-27.

13 TRINDADE, citado por RODRIGUES. História de Bom Despacho, p.51.

${ }^{14}$ Segundo o prof. Laércio, Luís Ribeiro da Silva é o mesmo Manoel Ribeiro da Silva de que fala o Pe. del Duca. Teria havido, apenas, uma alteração do nome Luís para Manoel, na tradição oral. Cf. RODRIGUES. História de Bom Despacho, p.67.

${ }^{15}$ RODRIGUES, op. cit. p.51.

16 Idem.

${ }^{17}$ Ibidem. p.61. 
De 1763 data o mais antigo título de concessão de sesmaria encontrado pelo prof. Laércio, e o favorecido é o já citado Antônio Rodrigues da Rocha. Na petição, assinada em 1763, informa o solicitante que

em dois de maio de 1758, com S.M. Gabriel da Silva Pera, (...) Antônio Dias Nogueira, Domingos Gonçalves Viana perferirão 14 armas de fogo, cavallos de cargas pa. comerem e cortarão o Rio Lambary tê o Rio São Francisco a desflorar terras e campos para criar gado bacum e cavallar estando este pedaço de sertão tê ali poboado de feras e negros do Mato, e com efeito se situarão; que dipois entrou e veio entrando mais gente. ${ }^{18}$

O documento de Antônio Rodrigues da Rocha reveste-se de grande importância para este estudo, pois, além de conter a primeira referência à presença de negros da região de Bom Despacho, vem revelar que, na realidade, foram eles os primeiros povoadores daquelas terras. Atrás desses "negros do mato" é que vai entrando mais gente.

Em diversos outros documentos, Laércio Rodrigues encontrou registros de que, "no território compreendido pelos rios Lambari e São Francisco, eram numerosos os núcleos tribais de escravos fugidos". ${ }^{19}$ Considerados sérios obstáculos ao processo do povoamento da região, esses quilombos eram combatidos por expedições que, para esse fim, se organizavam em Pitangui. Os expedicionários, "exterminando os quilombos das áreas enquistadas, ali lançam posses, alcançam sesmarias e estabelecem fazendas". ${ }^{20}$

Também Waldemar de Almeida Barbosa, em seu livro Negros e Quilombos em Minas Gerais, cita vários códices do Arquivo Público Mineiro em que se faz referência a quilombos nas cercanias de Bom Despacho. É o caso, por exemplo, do documento segundo o qual

o Alferes Bento Ribeiro, morador na paragem chamada Pará e Rio São João, freguesia de Pitangui, percorria em 1766, os matos de sua fazenda; ia com 2 camaradas brancos e 2 escravos. De repente, deram em um quilombo. Não podendo atacar, (...) regressou, convocou os capitães-do-mato de Itatiaiuçu, distante 14 léguas; com esses capitães-do-mato, mais camaradas e escravos, num total de 22 armas, foi atacado e destruído o quilombo e tudo o que nele

\footnotetext{
${ }^{18}$ RODRIGUES. História de Bom Despacho, p.36. Os grifos são meus.

${ }^{19}$ Ibidem. p.28.

${ }^{20}$ Idem.
} 
havia: 14 ranchos de capim, roças de milho, feijão, algodão, melancias e mais frutas. Foi morto o rei, mas quase a totalidade dos negros conseguiu escapar". ${ }^{21}$

Os quilombos são, pois, fator importante no povoamento da região de Bom Despacho: os negros, fugindo aos seus senhores, entram pelo sertão em busca de esconderijos onde se organizar como homens livres. Atrás deles vão os capitães-do-mato, que muitas vezes encontram pelo caminho lugares atraentes onde resolvem fixar residência. Foi o que aconteceu, por exemplo, com Francisco Ferreira Fontes, que, com autorização do governador Gomes Freire de Andrada,

entrou para o sertão entre o Lambari e o São Francisco, para dar combate a um quilombo. Gostou da paragem que descreveu como tendo "capacidade para se poderem cultivar aquelas terras para mantimentos como para criações e cavalariças", aí se fixou; quinze anos mais tarde, pediu sesmaria das terras e a obteve. ${ }^{22}$

Também o Capitão Inácio de Oliveira Campos, que tinha por ofício "limpar as estradas de ladrões e prender a negraria escapa em mocambos", ${ }^{23}$ por volta de 1760 "lançou posses na área que fica entre o Rio São Francisco, Córrego do Jacaré e Ribeirão dos Machados, em terras pertencentes aos municípios de Moema e Bom Despacho, conseguindo, em 06 de abril de 1764, sesmaria de três léguas na mencionada paragem". ${ }^{24}$

A toponímia é outra testemunha da proliferação de quilombos nas redondezas de Bom Despacho. Segundo Waldemar de Almeida Barbosa, menciona-se uma paragem chamada Quilombo em documentos de 1742, referentes à concessão de duas sesmarias na região: "a primeira, de Antônio Correia, situada 'entre o caminho do Gama e dos Goiás'; e a segunda, 'no meio do caminho do Gama e dos Goiás', perto do 'caminho antigo que vai de Pitangui para banda de Ibituruna'". ${ }^{25}$ Em 1789, o Alferes Antônio Roiz obtém sesmaria "no termo da Vila de Pitangui, no córrego chamado Quilombo, nas vertentes

\footnotetext{
${ }^{21}$ BARBOSA. Negros e quilombos em Minas Gerais, p.68.

${ }^{22}$ Ibidem. p.65.

${ }^{23}$ RODRIGUES. História de Bom Despacho, p.34.

${ }^{24}$ Idem.

${ }^{25}$ BARBOSA, op. cit. p.85.
} 
do Rio São João". ${ }^{26}$ Ainda hoje, há na zona rural de Bom Despacho um lugar de nome Quilombo, que fica no antigo caminho para Pitangui.

O negro cativo desempenhou também um papel relevante no povoamento da região, pois a ele cabia todo o trabalho braçal necessário ao estabelecimento das fazendas de gado e lavoura que vieram substituir a garimpagem na economia de Minas Gerais:

(...) entrantes, principalmente de Pitangui, transpuseram o São Francisco e estabeleceram-se em suas sesmarias, de modo que, nos últimos anos do século XVIII e princípios do XIX, alguns outros povoados já existiam, do outro lado do São Francisco. Ninguém, porém, se atrevia a essas entradas, nem se estabelecia, a não ser que estivesse provido de muitos escravos. ${ }^{27}$

Além disso, é importante observar que a concessão de sesmarias era vinculada ao número de escravos possuídos pelo requerente. ${ }^{28}$

O discurso pronunciado pelo Deputado Gustavo Xavier Capanema em sessão ordinária da Assembléia Provincial de julho de 1872 constitui documento de valor com relação à presença expressiva de cativos em Bom Despacho. Em defesa do projeto-de-lei que apresenta na ocasião, em que propõe a elevação da freguesia de Bom Despacho à categoria de vila, o Deputado Capanema argumenta que em Bom Despacho estão fixados os fazendeiros mais abastados do município de Pitangui, sendo todos eles possuidores de grande número de escravos. ${ }^{29}$

Ainda hoje, a presença dos negros cativos está documentada em algumas das fazendas mais antigas de Bom Despacho. Na fazenda do Sapé, propriedade da família Gontijo há várias gerações, embora já tenha sido demolido o muro de pedras secas levantado por escravos há aproximadamente 150 anos, conserva-se a casa-sede, construída também por eles, na mesma época (cf. Figura 3). A propriedade de José Fúlvio Cardoso possui ainda uma roda de madeira usada antigamente para castigar escravos, e a Fazenda Cachoeira, propriedade dos herdeiros de Antônio Lopes do Couto, conserva ainda três construções do período da escravidão: a casa-sede, um moinho d'água e um engenho de cana-de-açúcar (cf. Figuras 4, 5, 6, 7). A estrutura do

\footnotetext{
${ }^{26}$ BARBOSA. Negros e quilombos em Minas Gerais, p.21.

${ }^{27}$ Idem.

${ }^{28}$ BARBOSA. Negros e quilombos em Minas Gerais, p.166.

${ }^{29}$ Cf. RODRIGUES. História de Bom Despacho, p.98.
} 
engenho retrata bem a relação senhor-escravo, com o balcão central de onde o feitor podia fiscalizar o trabalho dos negros em todas as etapas da fabricação do açúcar.

As fazendas Santa Rosa do Picão, Piraquara e Colônia, as duas últimas antigos patrimônios das famílias Cardoso e Pereira, respectivamente, foram outros núcleos importantes de concentração negra, segundo depoimento do prof. Nicolau Leite, bom-despachense de rica memória cuja mãe foi criada por negras da Fazenda Colônia. Grande interessado na história da cidade, o prof. Nicolau Leite possuía documentos importantes a respeito, como os manuscritos do Pe. Nicolau Ângelo del Duca, que salvou de uma "limpeza" feita na igreja matriz. ${ }^{30}$ Além de documentação escrita e fotográfica, possuía também um vasto repertório de informações relativas à tradição oral de Bom Despacho, que incluía nomes e feitos de negros escravos ou a eles relacionados.

Destaca-se em seu depoimento a figura de Zacaria, ${ }^{31}$ escravo forte, "bom de serviço", que, embora bebendo diariamente uma dose de cachaça, viveu entre 110 e 112 anos. O negro Zacaria, que é citado em outros depoimentos como um dos introdutores da Língua do Negro da Costa em Bom Despacho, era guia de bois e foi quem carreou as pedras para a construção do cemitério da cidade.

A longevidade é mencionada com referência a diversos negros citados nos depoimentos. Entre eles, Dicoberto é outra figura de destaque, igualmente ligada à introdução da Língua do Negro da Costa em Bom Despacho e que, como Zacaria, teria ultrapassado os 100 anos de vida.

Também merece nota a história de uma escrava da Fazenda Piraquara que, sendo filha do senhor, o Major José Antônio da Silva Cardoso, conseguiu mandar o filho para um seminário. Orgulhosa da idéia de ser mãe de sacerdote, repetia sempre: "Os salões da Piraquara não deram ninguém, mas a senzala vai dar padre."

Há ainda o caso de Estanislau, capitão-do-mato que, com a abolição, passou ao ofício de seleiro, fabricando então, para amarrar animais, as mesmas cordas de couro que antes fabricava para laçar negros fugidos.

\footnotetext{
${ }^{30}$ Trata-se do Livro do Tombo da Paróquia de N. Sra. do Bom Despacho, em que se acham as "Breves Notícias...", já referidas neste capítulo, na nota 4.

${ }^{31}$ Citado em outros depoimentos - entre os quais o de Fiotinha, sua descendente - como Zé Caria.
} 


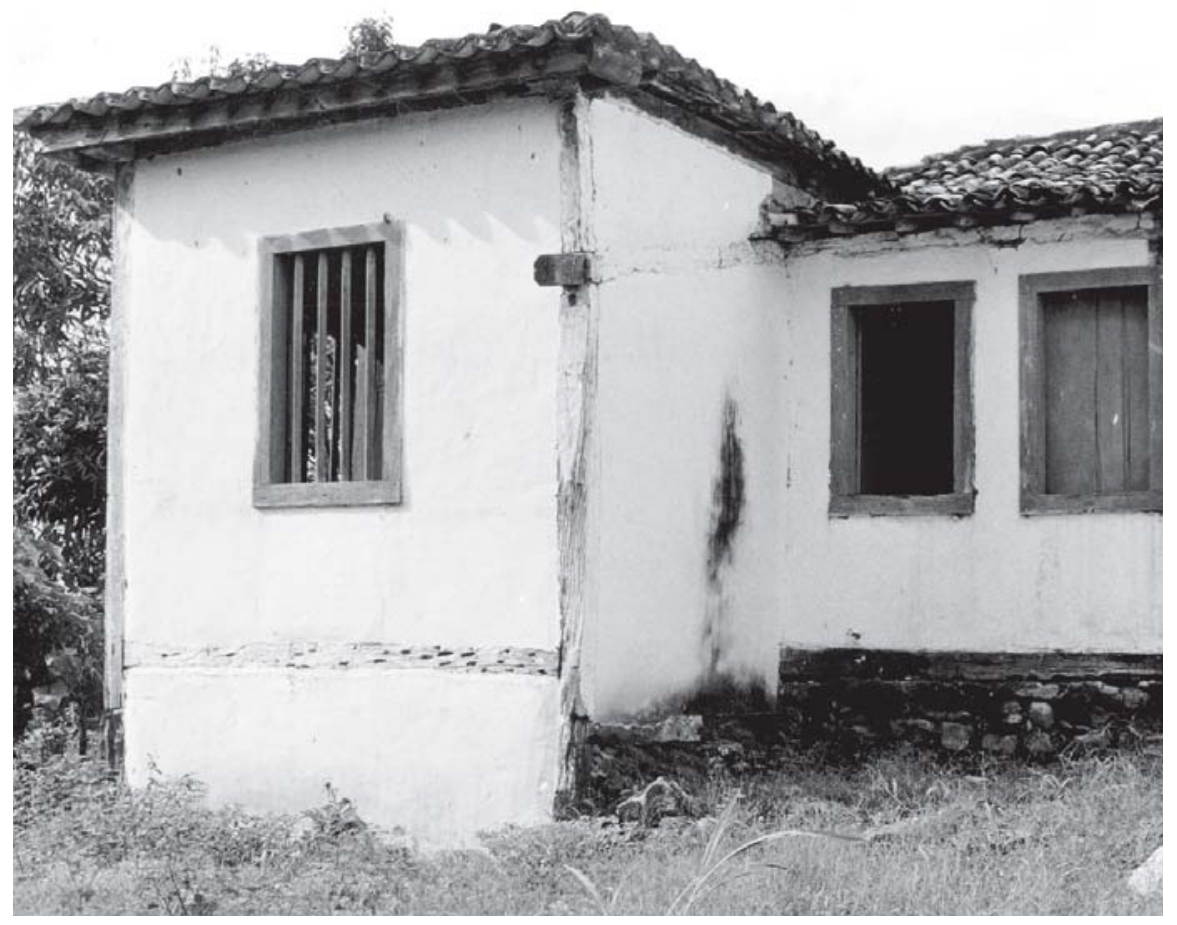

FIGURA 3 - Fazenda do Sapé, propriedade de Paulo de Tarso Gontijo. Detalhe da casa-sede, construída por escravos há mais de 150 anos. FOTO: Élida Queiroz de Araújo 
FIGURA 4 - Remanescentes do trabalho escravo na Fazenda da Cachoeira, propriedade dos herdeiros de Antônio Lopes do Couto. Detalhe lateral da casasede, cujas paredes, de pau a pique, se apóiam sobre uma base de pedra seca. FOTO: Élida Queiroz de Araújo
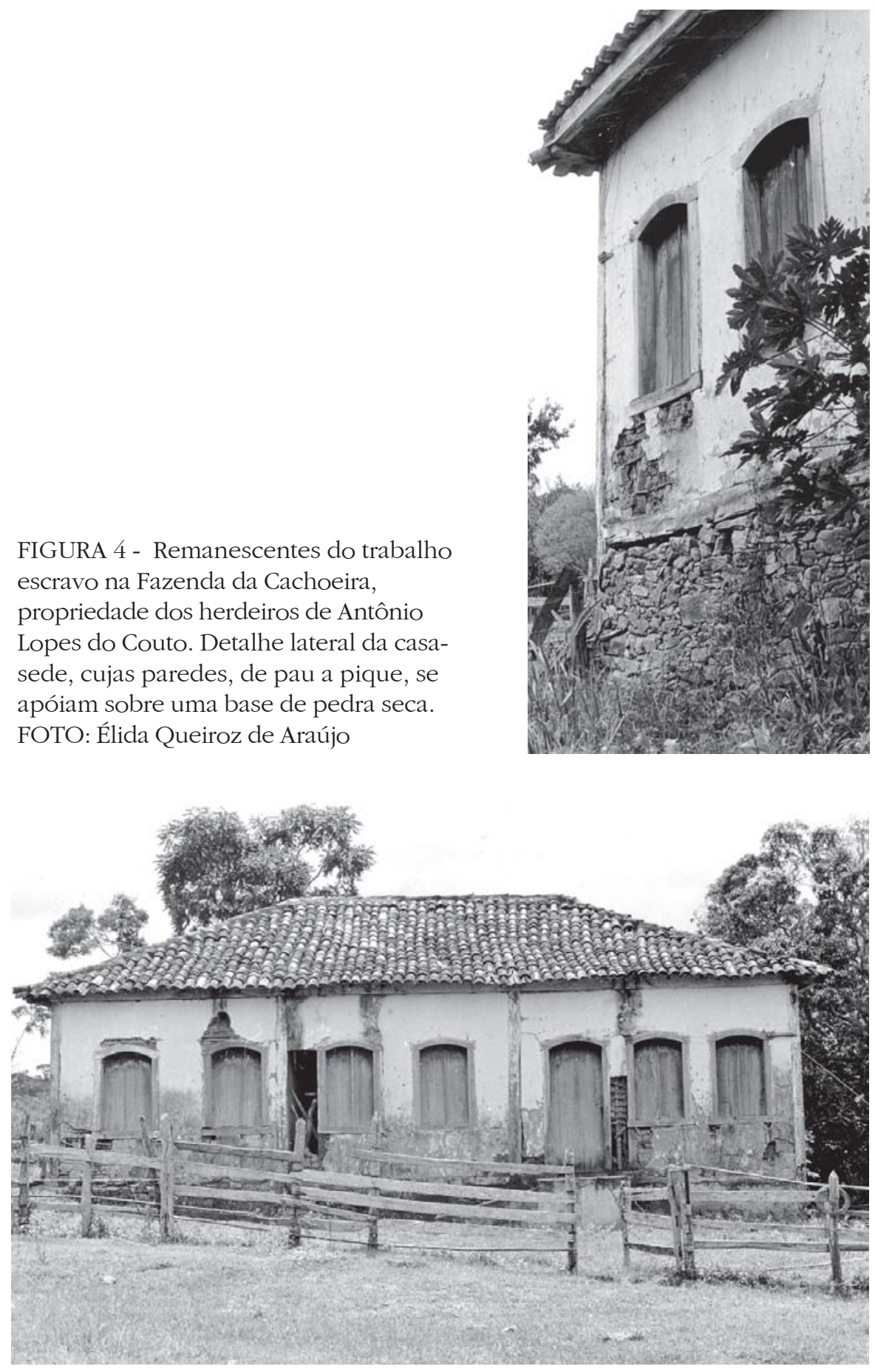


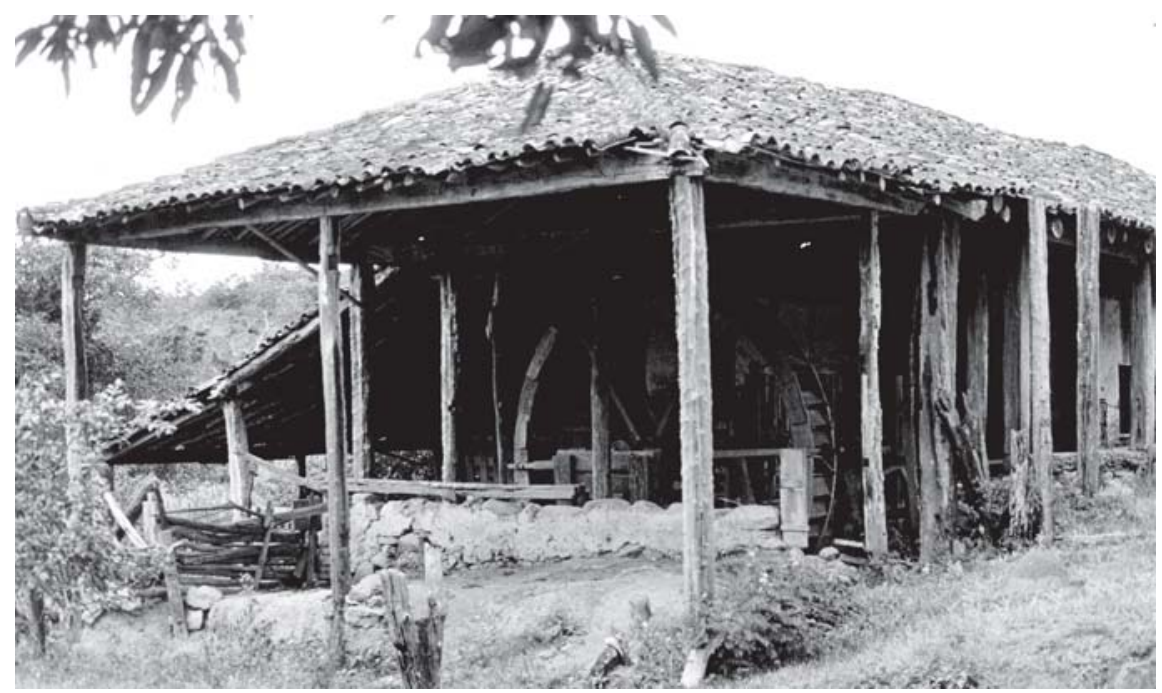

FIGURA 5 - Remanescentes do trabalho escravo na Fazenda da Cachoeira, propriedade dos herdeiros de Antônio Lopes do Couto. Engenho de canade-açúcar.

FOTO: Élida Queiroz de Araújo 


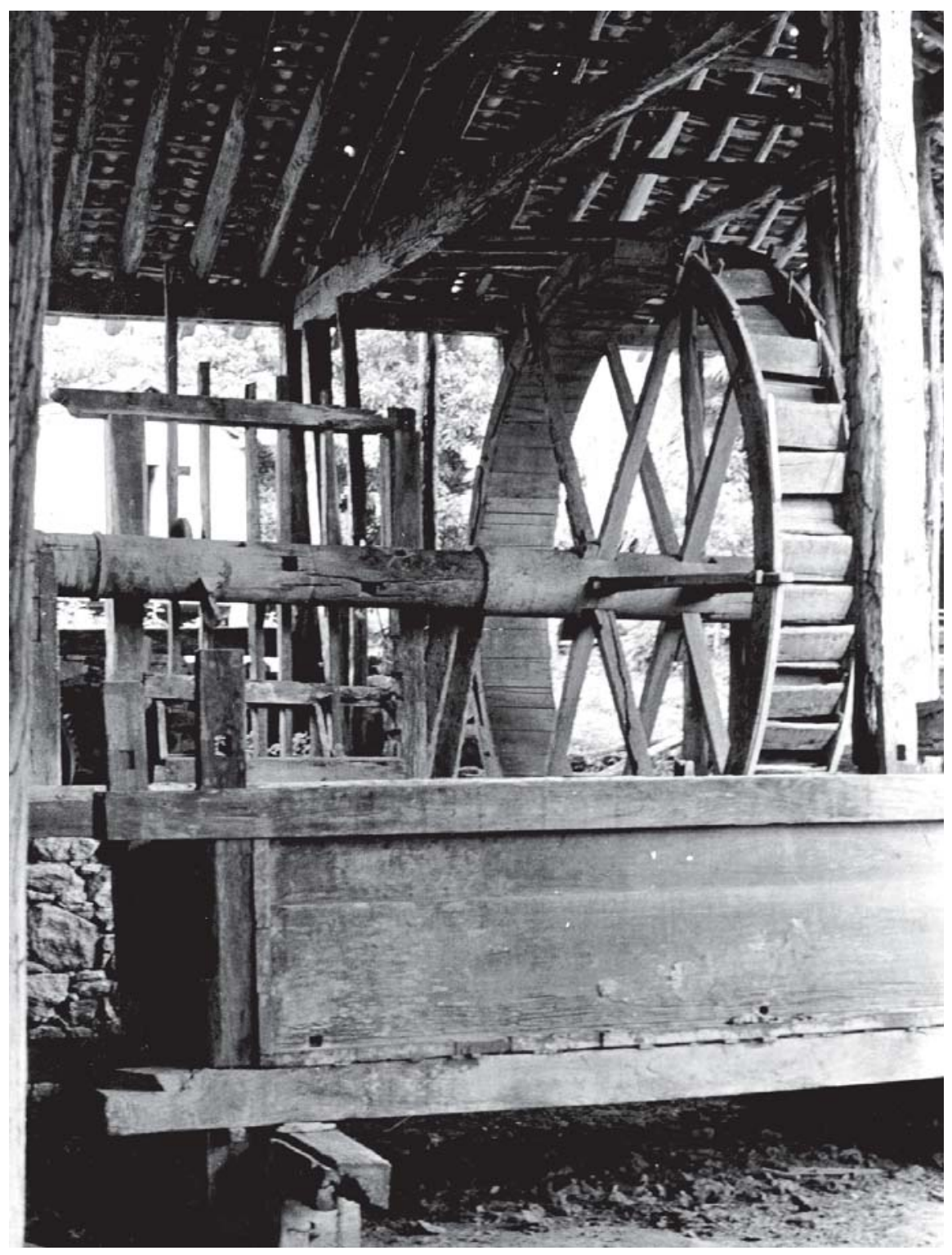

FIGURA 6 - Detalhe do engenho: roda d'água.

FOTO: Élida Queiroz de Araújo 


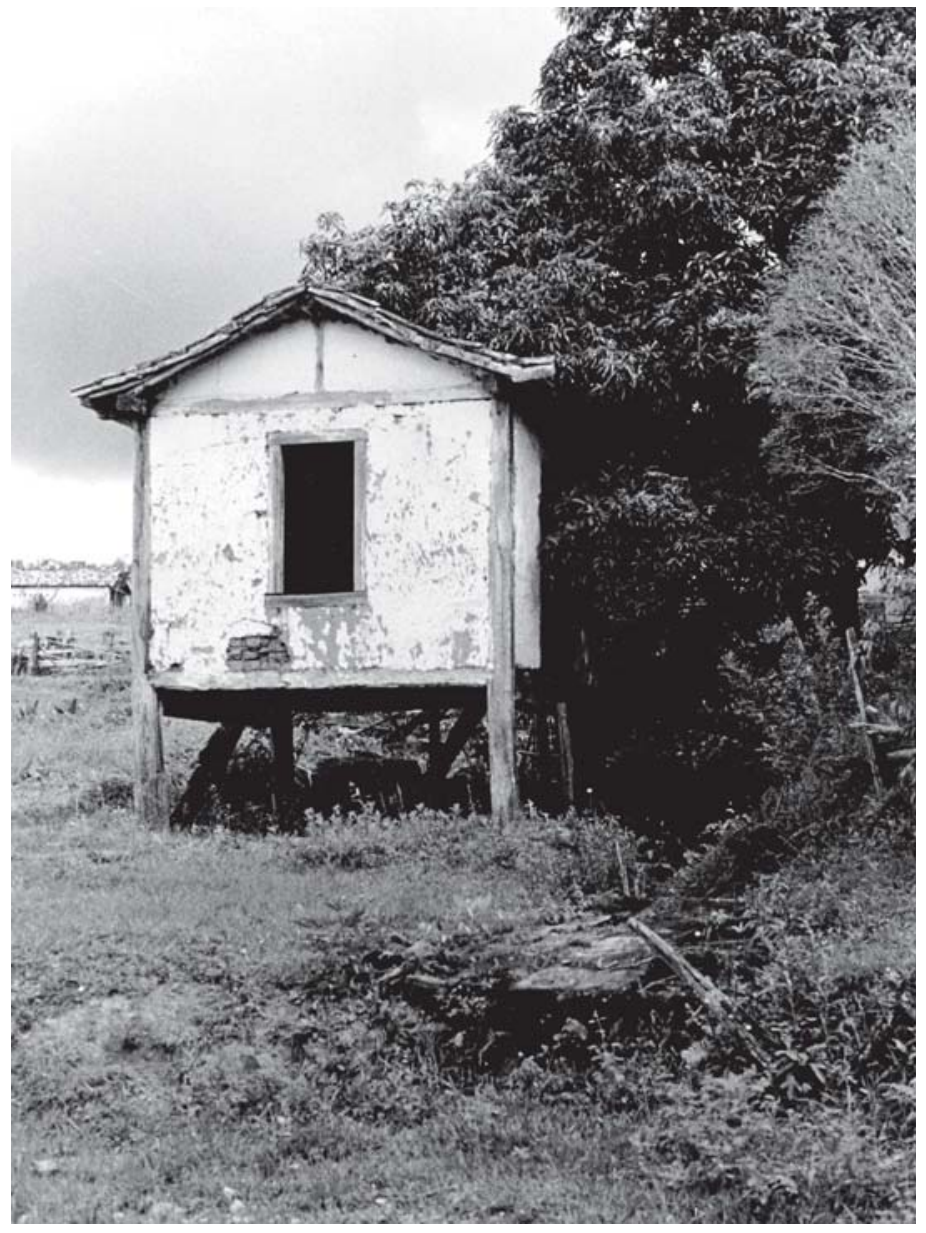

FIGURA 7 - Remanescentes do trabalho escravo na Fazenda da Cachoeira, propriedade dos herdeiros de Antônio Lopes do Couto. Moinho d'água.

FOTO: Élida Queiroz de Araújo 


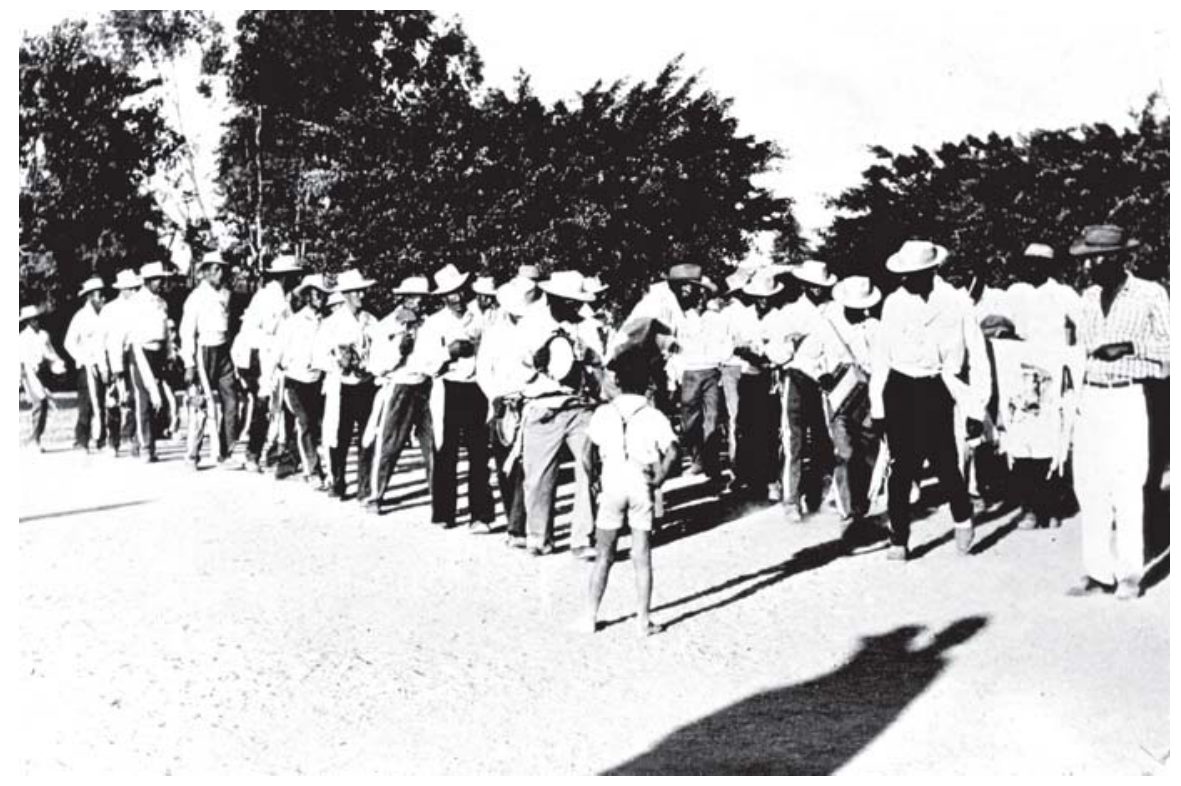

FIGURA 8 - Festa de Congado em Bom Despacho. O terno do Baiano, da Tabatinga, composto só de negros.

FOTO: Arquivo José Pessoa 


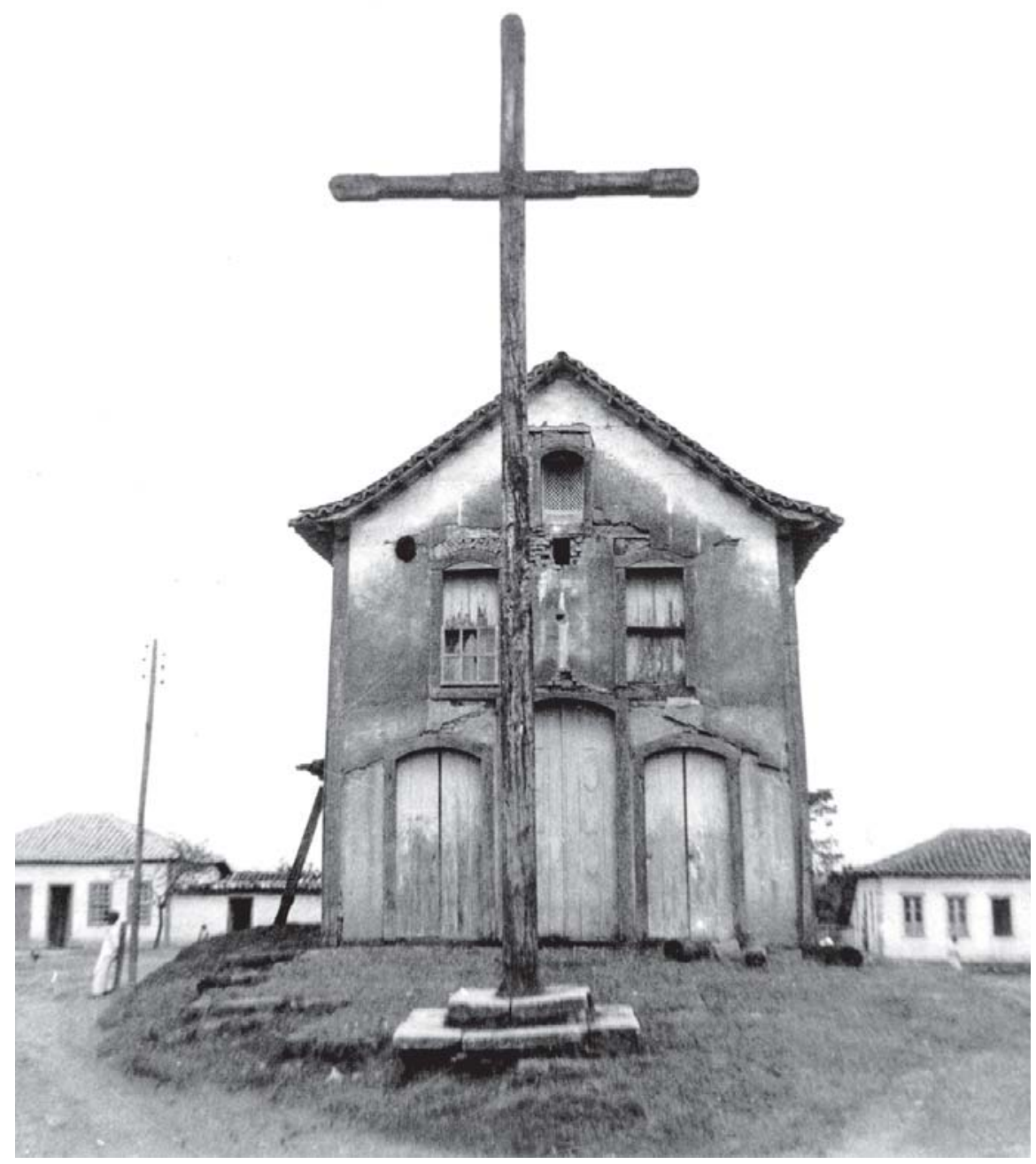

FIGURA 9 - Igreja do Rosário em Bom Despacho, demolida por volta de 1930. FOTO: Arquivo José Pessoa 
Domingos Leite, irmão do prof. Nicolau, também citou em seu depoimento muitos nomes e histórias de escravos de Bom Despacho. Entre eles há alguns falantes da Língua do Negro da Costa, como Cesário, negro corajoso, da senzala da Fazenda da Colônia, e João do Neco, homem rude que, ignorando as questões de doutrina sobre as quais o interpelava o Pe. Nicolau ${ }^{32}$ durante a cerimônia de seu primeiro casamento, respondeu com uma adivinha curiosa, em que é evidente a referência às relações branco-negro: "Ocê tá com muita prosa, eu vô lhe fazê uma pregunta: quantos tição tem no inferno e quantos botão tem na casa-grande?"

Também nas festas populares é marcante a presença do negro, a quem Bom Despacho deve a introdução do Congado, que ali se realiza ainda todos os anos, por ocasião das festas de N. Sra. do Rosário, nos meses de julho e agosto (Figuras 8 e 9).

Originalmente realizado apenas por negros, o Congado, ou Reinado, como é mais conhecido em Bom Despacho, foi durante muito tempo condenado pela Igreja como festa pagã. Na realidade, de acordo com o depoimento de Onézimo Pontes — o Dunga — capitão de terno ${ }^{33}$ que construiu a Sede do Congado em Bom Despacho, faziam parte da festa o feitiço e a cachaçada. Dunga relata muitos casos de feitiçaria entre os congadeiros, alguns em que ele mesmo é objeto de feitiço, e cita o próprio avô, Amadeu Pontes, como "moambeiro respeitado". Seduzida, entretanto, pela renda arrecadada pelo Congado, a Igreja acabou por incorporar a festa.

A fundação da Irmandade de N. Sra. do Rosário dos Pretos já em princípios do século XIX ${ }^{34}$ é mais uma evidência da participação significativa do negro na história de Bom Despacho.

Quanto aos dados estatísticos sobre a população negra de Bom Despacho, os mais antigos que se conhecem datam de 1813. Por essa época, registrou-se ali um total de 1.532 habitantes, dos quais 973 eram pretos e mulatos, perfazendo um percentual de $63,51 \%$, ou seja, mais da metade da população. ${ }^{35}$ De lá para cá, o número de negros vem caindo: em 1872, a população de cor ainda ultrapassa os

\footnotetext{
32 Possivelmente o já citado Pe. Nicolau Ângelo del Duca.

${ }^{33}$ Assim se denomina o responsável por um grupo de congadeiros.

${ }^{34}$ Cf. RODRIGUES. História de Bom Despacho, p.83.

35 Ibidem. p.80-81.
} 
50\%; mas em 1890 cai para 38,80\% e em 1940, para 13,51\%. Apenas em 1950 observa-se um pequeno crescimento para 20,81\%. ${ }^{36}$ Os recenseamentos que levaram em conta a cor dos indivíduos incluem os índios entre os pardos. No caso de Bom Despacho, porém, esses números correspondem ao de negros e mulatos, pois já "por ocasião da descoberta das riquezas auríferas de Pitangui (1709), o silvícola não se fazia presente na região ora estudada e pouquíssimos sinais há de sua eventual permanência ali, em outros tempos". ${ }^{37}$

No que diz respeito aos grupos africanos a que se ligam esses negros e mulatos, os dados disponíveis referem-se aos de Pitangui, no período de 1718 a 1723. Segundo artigo de Francisco Vidal Luna e Iraci del Nero da Costa, ${ }^{38}$ verifica-se ali pequena diferença entre bantos e sudaneses, a favor dos primeiros. Os sudaneses não chegam a ser maioria em Pitangui, embora sua população aumente durante o período da mineração, o que se deve sobretudo ao crescimento dos minas, da ordem de $283,1 \%$ (cf. Tabela 1). Até onde nos foi possível verificar, já que não é objetivo deste trabalho estabelecer a etimologia dos vocábulos africanos da Língua do Negro da Costa, os dados lingüísticos parecem confirmar o predomínio dos bantos na região.

Enfim, quer tenham predominado os bantos, quer os sudaneses, o negro desempenhou papel relevante no povoamento de Bom Despacho. Na condição de quilombola, adentrando o sertão em busca da liberdade, ou na condição de cativo, acompanhando seu senhor no estabelecimento de fazendas de criação de gado e lavoura, participou de modo ativo na formação da cultura regional. A Língua do Negro da Costa, como as festas do Congado, é documento vivo da presença marcante dos africanos e de seus descendentes na região.

${ }^{36}$ IBGE. Recenseamento geral de 1972; Recenseamento geral de 1890; Censo demográfico de 1940; Censo demográfico de 1950.

${ }^{37}$ RODRIGUES. História de Bom Despacho, p.14.

${ }^{38}$ LUNA, COSTA. O Estado de S.Paulo, 2 mar. 1980, p.6-7. 


\section{TABELA 1}

Repartição dos escravos africanos da Vila de Pitangui, segundo a origem, no período de 1718 a 1723.

\begin{tabular}{l|c|c|c|c|c}
\hline \multirow{2}{*}{$\begin{array}{c}\text { GRANDES GRUPOS } \\
\text { E "NAÇÕES" }\end{array}$} & \multicolumn{5}{|c}{ ANO } \\
\cline { 2 - 6 } Sudaneses & 1718 & 1719 & 1720 & 1722 & 1723 \\
\hline Mina & 77 & 114 & 119 & 294 & 295 \\
\hline Cabo Verde & 19 & 20 & 13 & 28 & 27 \\
\hline Outras & 11 & 14 & 13 & 25 & 16 \\
\hline Total de Sudaneses & 107 & 148 & 145 & 347 & 338 \\
\hline Bantos & & & & & \\
\hline Bengala & 36 & 40 & 38 & 59 & 69 \\
\hline Angola & 15 & 30 & 28 & 59 & 74 \\
\hline Congo & 40 & 63 & 59 & 131 & 108 \\
\hline Monjolo & 16 & 21 & 23 & 37 & 28 \\
\hline Moçambique & 07 & 09 & 07 & 14 & 13 \\
\hline Loango & 12 & 18 & 23 & 42 & 26 \\
\hline Outras & 07 & 09 & 16 & 21 & 23 \\
\hline Total de Bantos & 133 & 190 & 194 & 363 & 341 \\
\hline Total Geral & 240 & 338 & 339 & 710 & 679 \\
\hline
\end{tabular}

FONTE: LUNA, COSTA. A presença do elemento sudanês nas Minas Gerais, p.7. 


\section{NAS CAFUAS DA TABATINGA, UMA LIINGUA AFRICANA}

Lembro muito, lembro da Tabatinga no tempo que não tinha casa. Tinha lá um... umas cafua, umas coisa assim. E a gente ia lá buscar, buscar tabatinga. A tabatinga servia no lugar de cal, pra caiar casa, né? Essas casas pobres. A gente buscava lá. (...) Daí o nome de Tabatinga. Nicolau Leite

Quem chegava a Bom Despacho vindo de Pitangui pelo antigo caminho de terra encontrava à entrada da cidade, até meados deste século, um grupo de casinhas de capim espalhadas pelo morro de argila branca que veio a dar nome ao lugar. A Tabatinga era então um pequeno aglomerado de cafuas, habitadas predominantemente por negros e alguns poucos brancos. No alto do morro havia uma capela barroca e um cruzeiro. O caminho que se abriu da Tabatinga até ele recebeu o nome de Cruz do Monte (Figuras 10 e 11). Tabatinga e Cruz do Monte são hoje duas ruas da periferia de Bom Despacho (Figuras 12 e 13), compondo uma só realidade sócio-cultural, a contrastar com o resto da cidade. Os falantes da Língua do Negro da Costa concentram-se nessa região, onde realizamos toda a pesquisa de campo, à exceção de algumas gravações de material lingüístico feitas em bares do centro. O inquérito sócio-econômico, que teve como objetivo traçar o perfil dos falantes da Língua do Negro da Costa, foi realizado em 1981 e apontou, em 234 casas visitadas, um total de 932 habitantes, dos quais 207 utilizam ou, pelo menos, compreendem a Língua do Negro da Costa. ${ }^{2}$ Os dados relativos à cor

\footnotetext{
${ }^{1}$ Nicolau Leite era um dos maiores possuidores de informações históricas sobre Bom Despacho, conforme já foi dito no capítulo anterior.

${ }^{2} \mathrm{O}$ conceito de falante aqui adotado inclui, portanto, aquele que possui apenas o conhecimento passivo da língua.
} 
e ao sexo indicaram um predomínio absoluto de falantes de cor -117 pretos e 54 mulatos para 36 brancos (cf. Tabela 2) - e, em menor escala, do sexo masculino sobre o feminino - 123 homens e 84 mulheres (cf. Tabela 3). Anotou-se também o domicílio dos usuários da Língua do Negro da Costa, tendo-se verificado predominância da Tabatinga sobre a Cruz do Monte - onde residem 164 e 43 falantes, respectivamente (cf. Tabela 4).

O falante típico da Língua do Negro da Costa nasceu em Bom Despacho, na Tabatinga ou na Cruz do Monte; é católico, solteiro, e tem entre 11 e 30 anos de idade; possuindo o curso primário completo, ${ }^{3}$ sabe ler e escrever (cf. Tabela 5 a 9).

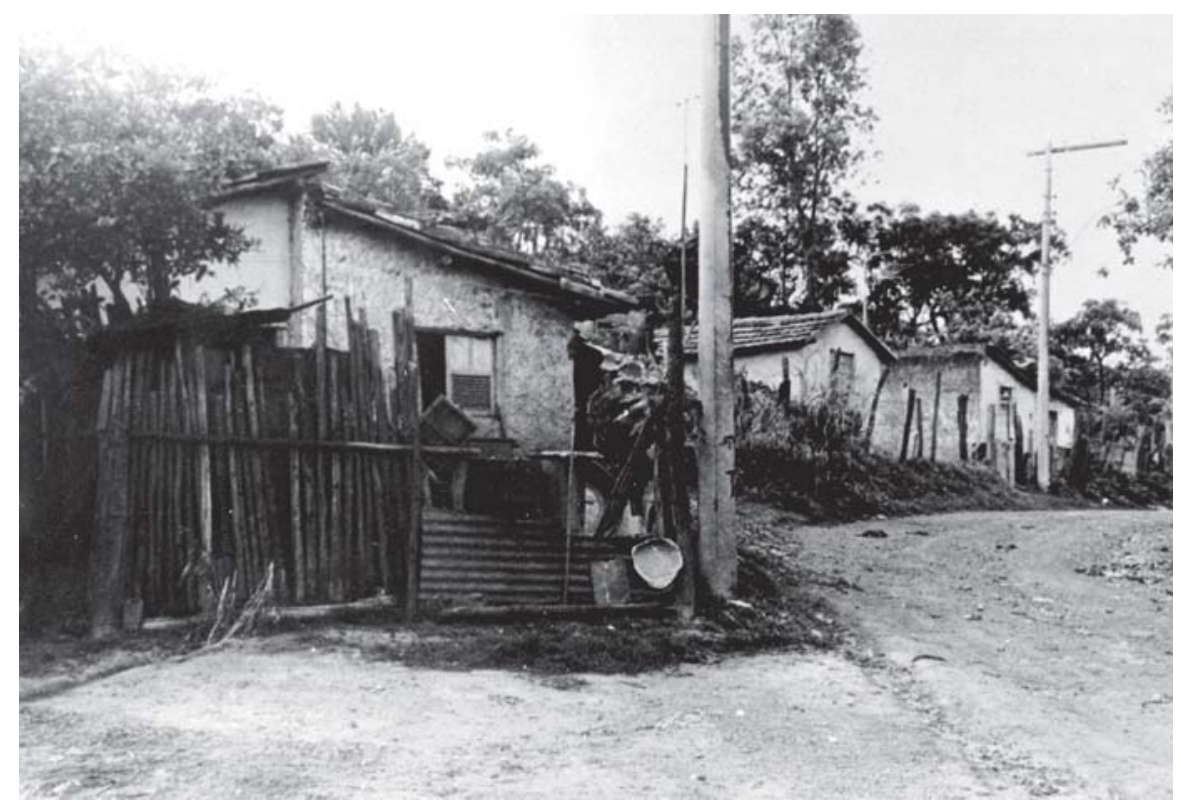

FIGURA 10 - A Rua Tabatinga (à direita) vista do cruzamento com a Cruz do Monte.

FOTO: Fernando Cabral

\footnotetext{
${ }^{3}$ A estrutura de ensino atualmente em vigor no Brasil reúne o primário e o ginásio sob a mesma denominação de ensino fundamental. Optou-se, no entanto, pela terminologia, já superada, que isola as duas fases, por refletir melhor a realidade dos informantes, que, na maioria, cursaram apenas as primeiras quatro séries do ensino fundamental, correspondentes ao antigo curso primário.
} 


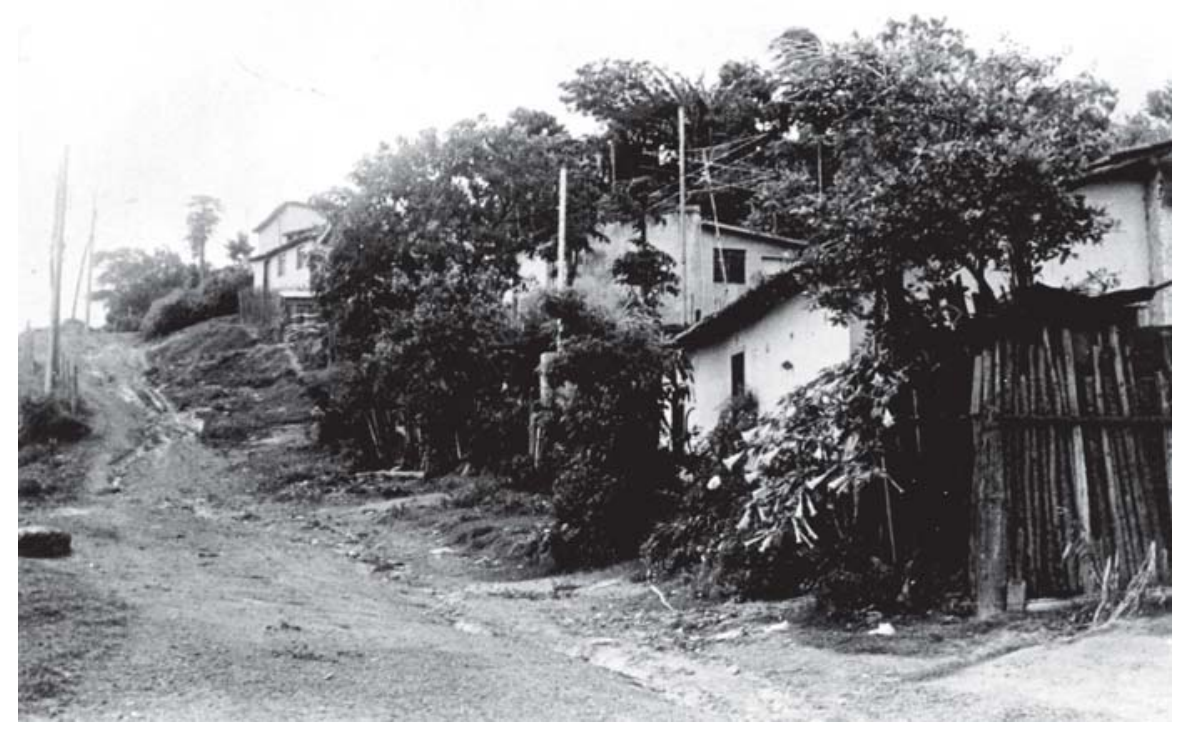

FIGURA 11 - A Rua Cruz do Monte (à esquerda) vista do cruzamento com a Tabatinga.

FOTO: Fernando Cabral 


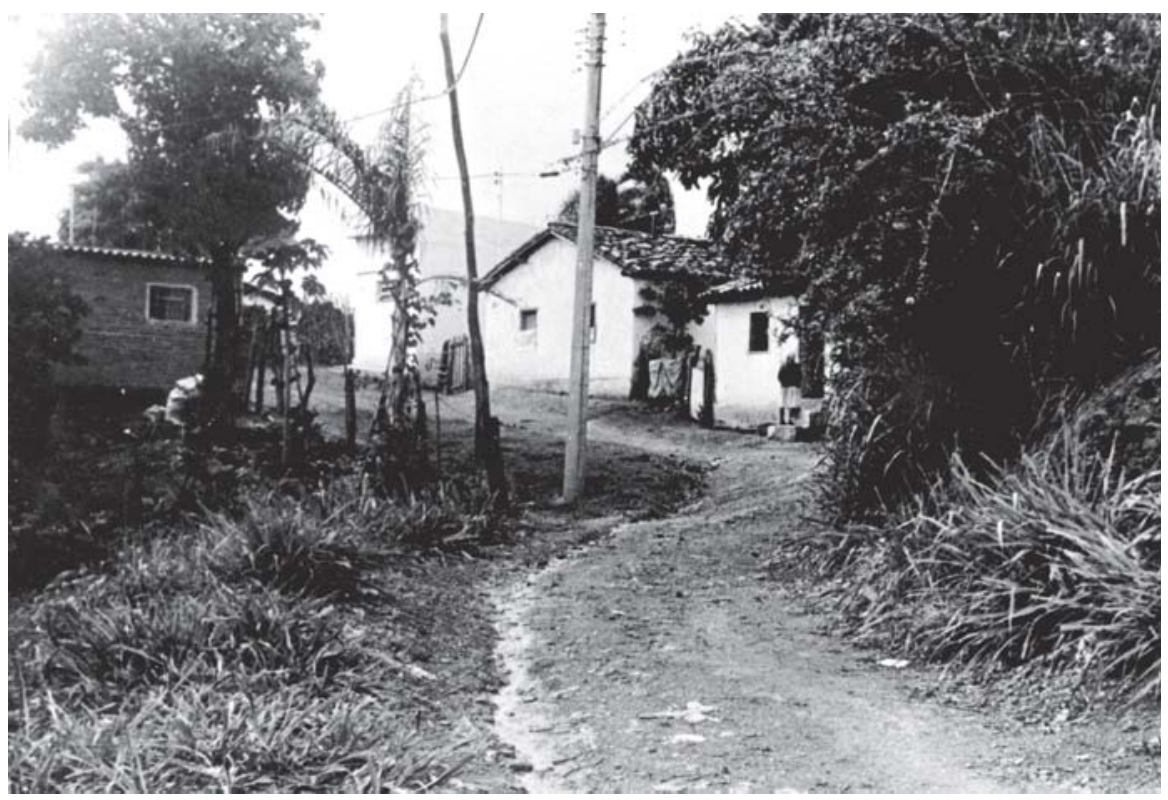

FIGURA 12 - Alto da Rua Cruz do Monte, antigo caminho para o cruzeiro. FOTO: Fernando Cabral 


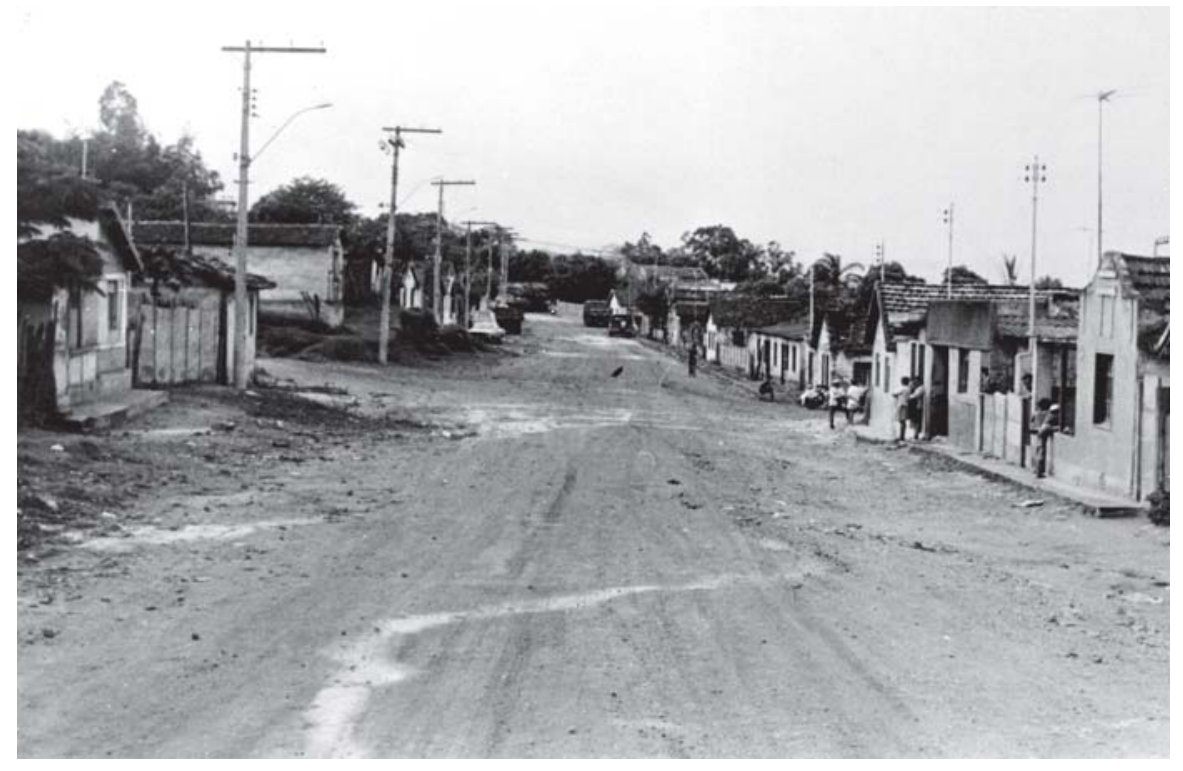

FIGURA 13 - Trecho da Rua Tabatinga: a eletricidade chegou, o esgoto não. FOTO: Fernando Cabral 
TABELA 2

Distribuição dos falantes da LNC segundo a cor

\begin{tabular}{|c|c|c|}
\hline COR FALANTES & Números absolutos & $\%$ \\
\hline Pretos & 117 & 56,5 \\
\hline Mulatos & 54 & 26,1 \\
\hline Brancos & 36 & 17,4 \\
\hline Total & 207 & 100,0 \\
\hline
\end{tabular}

FONTE: Pesquisa de campo - maio de 1981.

TABELA 3

Distribuição dos falantes da LNC segundo o sexo

\begin{tabular}{|c|c|c|}
\hline SEXO FALANTES & Números absolutos & $\%$ \\
\hline Masculino & 123 & 59,4 \\
\hline Feminino & 84 & 40,6 \\
\hline Total & 207 & 100,0 \\
\hline
\end{tabular}

FONTE: Pesquisa de campo - maio de 1981.

TABELA 4

Distribuição dos falantes da LNC segundo o domicílio

\begin{tabular}{|c|c|c|}
\hline DOMICÍLIO & Números absolutos & $\%$ \\
\hline Tabatinga & 164 & 79,2 \\
\hline Cruz do Monte & 43 & 20,8 \\
\hline Total & 207 & 100,0 \\
\hline
\end{tabular}

FONTE: Pesquisa de campo - maio de 1981. 
TABELA 5

Distribuição dos falantes da LNC segundo o local de nascimento

\begin{tabular}{l|c|c}
\hline $\begin{array}{l}\text { FOCAL } \\
\text { DE NASCIMENTO }\end{array}$ & Números absolutos & $\%$ \\
\hline $\begin{array}{l}\text { Bom Despacho - Tab./Cruz do } \\
\text { Monte }\end{array}$ & 45 & 39,5 \\
\hline Bom Despacho - outros bairros & 44 & 38,6 \\
\hline Bom Despacho - Total & 89 & 78,1 \\
\hline Outros Municípios & 23 & 20,2 \\
\hline Não informado & 02 & 1,7 \\
\hline Total & 114 & 100,0 \\
\hline
\end{tabular}

FONTE: Pesquisa de campo - julho de 1981.

TABELA 6

Distribuição dos falantes da LNC segundo a religião

\begin{tabular}{|c|c|c|}
\hline RELIGIÃO $\quad$ FALANTES & Números absolutos & $\%$ \\
\hline Católica & 112 & 98,2 \\
\hline Outras & - & - \\
\hline Nenhuma & 02 & 1,8 \\
\hline Total & 114 & 100,0 \\
\hline
\end{tabular}

FONTE: Pesquisa de campo - julho de 1981. 
TABELA 7

Distribuição dos falantes da LNC segundo o estado civil

\begin{tabular}{l|c|c}
\hline ESTADO CIVIL & Números absolutos & $\%$ \\
\hline Solteiros & 67 & 58,8 \\
\hline Casados & 31 & 27,2 \\
\hline Amasiados & 04 & 3,5 \\
\hline Desquitados/divorciados & 01 & 0,9 \\
\hline Separados & 04 & 3,5 \\
\hline Viúvos & 07 & 6,1 \\
\hline Total & 114 & 100,0 \\
\hline
\end{tabular}

FONTE: Pesquisa de campo - julho de 1981.

TABELA 8

Distribuição dos falantes da LNC segundo a idade

\begin{tabular}{l|c|c}
\hline FALANTES & Números absolutos & $\%$ \\
\hline $0-10$ & 01 & 0,9 \\
\hline $11-20$ & 36 & 31,6 \\
\hline $21-30$ & 36 & 31,6 \\
\hline $31-40$ & 17 & 14,9 \\
\hline $41-50$ & 11 & 9,6 \\
\hline+ de 50 & 11 & 9,6 \\
\hline Não informada & 02 & 1,8 \\
\hline Total & 114 & 100,0 \\
\hline
\end{tabular}

FONTE: Pesquisa de campo - julho de 1981. 
TABELA 9

Distribuição dos falantes da LNC segundo a escolaridade

\begin{tabular}{|c|c|c|}
\hline ESCOLARIDADE $\quad$ FALANTES & Números absolutos & $\%$ \\
\hline Nenhuma (analfabeto) & 14 & 12,3 \\
\hline MOBRAL & - & - \\
\hline Primário incompleto & 25 & 21,9 \\
\hline Prim. compl. ou gin. incompleto & 63 & 55,3 \\
\hline $\begin{array}{l}\text { Gin. completo ou } 2^{\circ} \text { grau } \\
\text { incompleto }\end{array}$ & 07 & 6,1 \\
\hline $2^{\underline{o}}$ grau completo & 04 & 3,5 \\
\hline Não informada & 01 & 0,9 \\
\hline Total & 114 & 100,0 \\
\hline
\end{tabular}

FONTE: Pesquisa de campo - julho de 1981.

Tradicionalmente se associa o nome da Tabatinga ao crime e à malandragem, o que vem a constituir o primeiro traço a distingui-la de sua vizinha-irmã Cruz do Monte. Esse traço se evidenciou durante as entrevistas, quando se pôde observar em alguns dos habitantes da Tabatinga uma grande preocupação com a imagem que deles faz o resto da cidade. Alegando que ali se trabalha como em qualquer outro lugar, consideram totalmente injusta a fama de antro de malandragem que acompanha a história da rua. O Sr. Antônio Paiva, dono de bar, falando detidamente sobre a necessidade de se recuperar a imagem negativa da Tabatinga, relatou histórias de assassinatos ocorridos ali, no passado, que, segundo ele, são os responsáveis pela má fama do lugar.

Desde os nossos primeiros contatos com a população, o problema do estigma da marginalidade veio à tona. Encontramos, inicialmente, uma certa resistência por parte dos habitantes quanto a fornecer informações sobre a Língua do Negro da Costa. Muitos deles, embora 
apontados por outros como falantes, declaravam desconhecer a língua, o que, evidentemente, dificultava o trabalho de pesquisa. Entretanto, à medida que se intensificou nosso contato com a população, o relacionamento entre pesquisador e informante foi se tornando mais tranqüilo, relaxado, e a explicação para a resistência inicial surgiu da boca dos próprios entrevistados: temia-se que a estranha interessada em identificar falantes da Língua do Negro da Costa fosse representante da repressão policial, ocupada em fazer ali uma devassa, com o objetivo de prender marginais. "Ainda mais agora que tem polícia feminina", alegou D. Maria das Dores Silva, justificando seu temor. Mais de uma vez ouvimos referência a boatos sobre a prisão dos falantes da língua, que — também chamada de "gíria" ou "gíria da Tabatinga" — seria considerada pela repressão como privativa de malandros e criminosos.

Entretanto, de acordo com os resultados da pesquisa de campo, o falante típico da Língua do Negro da Costa trabalha como lavrador ou pedreiro, se é homem, e como dona-de-casa, lavadeira ou empregada doméstica, se mulher; recebendo menos de dois salários mínimos, mora em casa própria, de alvenaria, com serviços de água e energia elétrica, mas sem rede de esgoto (cf. Tabela 10 a 14).

Assim, sumariamente descritas, as condições de moradia parecem não corresponder exatamente ao que se observa in loco. Por isso, torna-se necessário acrescentar à descrição de base quantitativa alguns detalhes de ordem qualitativa, como, por exemplo, o fato de que grande parte das construções da região tem o piso de terra ou cimento e não possui reboco nem mesmo na face externa das paredes (cf. Figuras 14 e 15). Observa-se, também, que, embora as ruas sejam servidas de rede de água, dificilmente se encontra uma casa com instalações hidráulicas: o que se tem, em geral, é um tanque do lado de fora, de onde se retira com balde a água necessária para as mais diversas atividades - como a preparação de alimentos, a higiene corporal ou a limpeza da casa. É também no quintal que se localizam os banheiros, ou melhor, as privadas, quando existem (cf. Figura 16).

Neste ponto é interesante ressaltar o fato de ser a Língua do Negro da Costa até hoje uma língua de negros: embora alguns dos falantes desconheçam sua origem, chegando a afirmar que foi inventada ali mesmo pelo povo da rua, numa clara manifestação de inconsciência de sua africanidade, eles ainda são predominantemente — 82,61\% — homens de cor (cf. Tabela 2). Portanto, apesar do processo de urbanização, que substituiu as cafuas africanas por habitações de alvenaria idênticas às dos brancos, com os quais os negros convivem 
lado a lado, a Tabatinga continua se configurando como uma comunidade negra. A mistura que ali se verifica não reflete, de modo algum, um "embranquecimento" da população. Não houve ascensão social do negro, a quem a "casa-grande" permanece inacessível, no centro da cidade. A "senzala" é que se abriu aos brancos, promovendo, na Tabatinga como nos milhares de favelas dos grandes centros urbanos, a igualdade na pobreza. Conseqüentemente, passam a recair sobre todo o grupo os preconceitos seculares que associam o preto à baixeza, à vadiagem e ao crime.

Por isso, a ameaça constante da repressão policial que paira sobre a vida dos moradores da Tabatinga - seja em sua própria fantasia, seja, de forma muito mais concreta, através da ronda infalível que ali faz todas as noites um camburão da Polícia nada mais é, de acordo com nosso ponto de vista, do que um reflexo do preconceito racial tão bem expresso no dito popular: "Preto parado é suspeito, correndo é ladrão."

TABELA 10

Distribuição dos falantes da LNC segundo a profissão

\begin{tabular}{l|c|c|c|c|c|c}
\hline & \multicolumn{2}{r|}{ FALANTES } & \multicolumn{3}{|c|}{ Números absolutos } & \multicolumn{4}{|c}{$\%$} \\
\cline { 2 - 8 } PROFISSÃO & $\mathrm{H}$ & $\mathrm{M}$ & $\mathrm{T}$ & $\mathrm{H}$ & $\mathrm{M}$ & $\mathrm{T}$ \\
\hline Lavrador & 11 & 02 & 13 & 9,6 & 1,8 & 11,4 \\
\hline Pedreiro & 10 & - & 10 & 8,8 & - & 8,8 \\
\hline Dona-de-casa & - & 10 & 10 & - & 8,8 & 8,8 \\
\hline Lavadeira & - & 05 & 05 & - & 4,4 & 4,4 \\
\hline Doméstica & - & 05 & 05 & - & 4,4 & 4,4 \\
\hline Estudante & 05 & 03 & 08 & 4,4 & 2,6 & 7,0 \\
\hline Outras & 44 & 15 & 59 & 38,6 & 13,2 & 51,8 \\
\hline Sem profissão & 01 & 03 & 04 & 0,9 & 2,6 & 3,5 \\
\hline Total & 71 & 43 & 114 & 62,3 & 37,7 & 100,1 \\
\hline
\end{tabular}

FONTE: Pesquisa de campo - julho de 1981. 
TABELA 11

Distribuição dos falantes da LNC segundo a renda

\begin{tabular}{l|c|c}
\hline FALANTES & Números absolutos & $\%$ \\
\hline RENDA & 35 & 30,7 \\
\hline Salário mínimo & 09 & 7,9 \\
\hline Acima do salário mínimo* & 41 & 36,8 \\
\hline Sem rendimentos & 27 & 23,7 \\
\hline Não informada & 02 & 1,8 \\
\hline Total & 114 & 100,0 \\
\hline
\end{tabular}

FONTE: Pesquisa de campo - julho de 1981.

*Entre R \$239,18 e R \$ 697,61 - média de R \$ 407,39 - o que representa menos de dois salários mínimos (o salário mínimo na época correspondia a $\mathrm{R} \$ 209,28$ ).

TABELA 12

Distribuição dos falantes da LNC segundo a condição de ocupação do domicílio

\begin{tabular}{l|c|c}
\hline FALANTES & Números absolutos & $\%$ \\
$\begin{array}{l}\text { COND. DE DO DOMICÍlIO } \\
\text { OCUPa própria }\end{array}$ & 85 & 74,6 \\
\hline Casa alugada & 22 & 19,3 \\
\hline Casa cedida & 07 & 6,1 \\
\hline Total & 114 & 100,0 \\
\hline
\end{tabular}

FONTE: Pesquisa de campo - julho de 1981. 
TABELA 13

Distribuição dos falantes da LNC segundo o tipo de construção do domicílio

\begin{tabular}{l|c|c}
\hline $\begin{array}{l}\text { CONSTR. } \\
\text { FO DOMICÍlio }\end{array}$ & Números absolutos & $\%$ \\
\hline Alvenaria & 110 & 96,5 \\
\hline Pau a pique & 04 & 3,5 \\
\hline Total & 114 & 100,0 \\
\hline
\end{tabular}

FONTE: Pesquisa de campo - julho de 1981.

TABELA 14

Distribuição dos falantes da LNC segundo a infra-estrutura básica do domicílio

\begin{tabular}{l|c|c}
\hline $\begin{array}{l}\text { INFRA- } \\
\text { ESTRUT. BÁSICA }\end{array}$ & Números absolutos* & $\%$ \\
\hline Água & 103 & 90,4 \\
\hline Energia Elétrica & 88 & 77,2 \\
\hline Esgoto & 06 & 5,3 \\
\hline
\end{tabular}

FONTE: Pesquisa de campo - julho de 1981.

*O total de informantes aqui é 114. Esse número não coincide com a soma da primeira coluna da tabela pelo fato de um mesmo falante poder ter sido computado até três vezes, na medida em que seu domicílio fosse servido de água, esgoto e energia elétrica. 


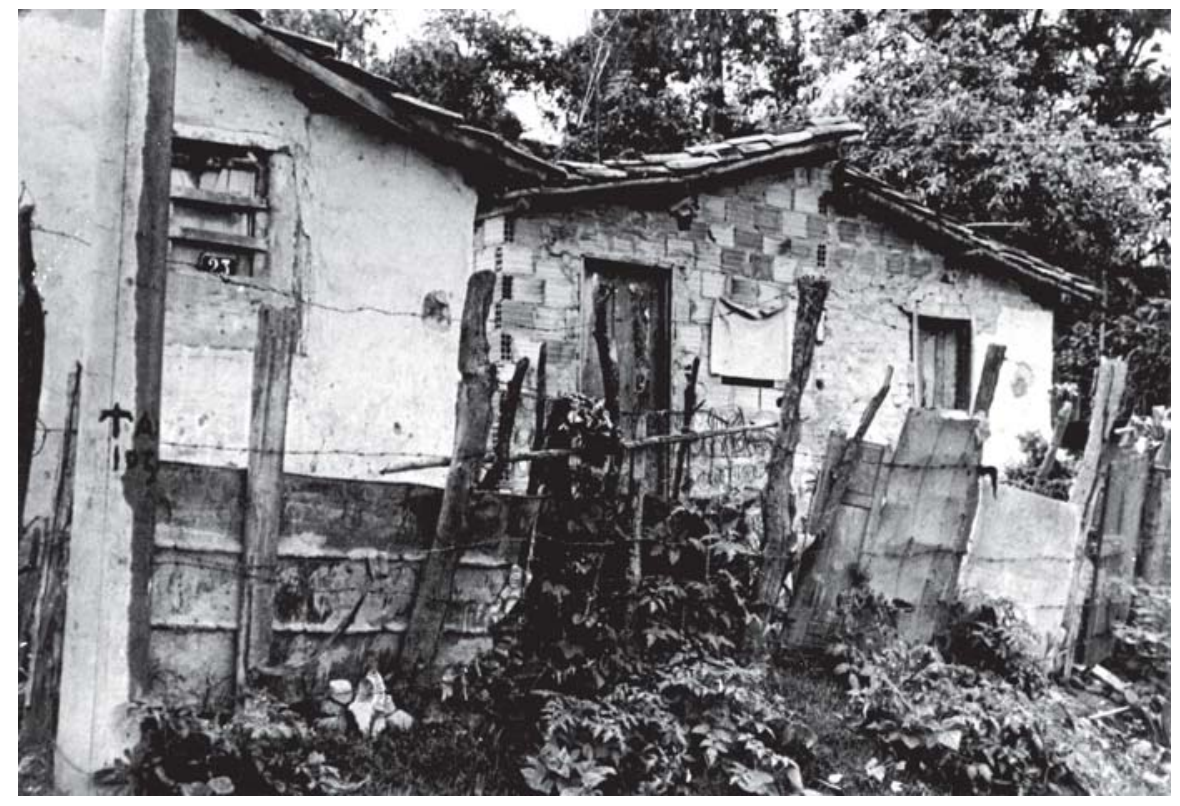

FIGURA 14 - Vista externa de habitações da Tabatinga, em que se percebe a ausência de reboco nas paredes.

FOTO: Fernando Cabral 


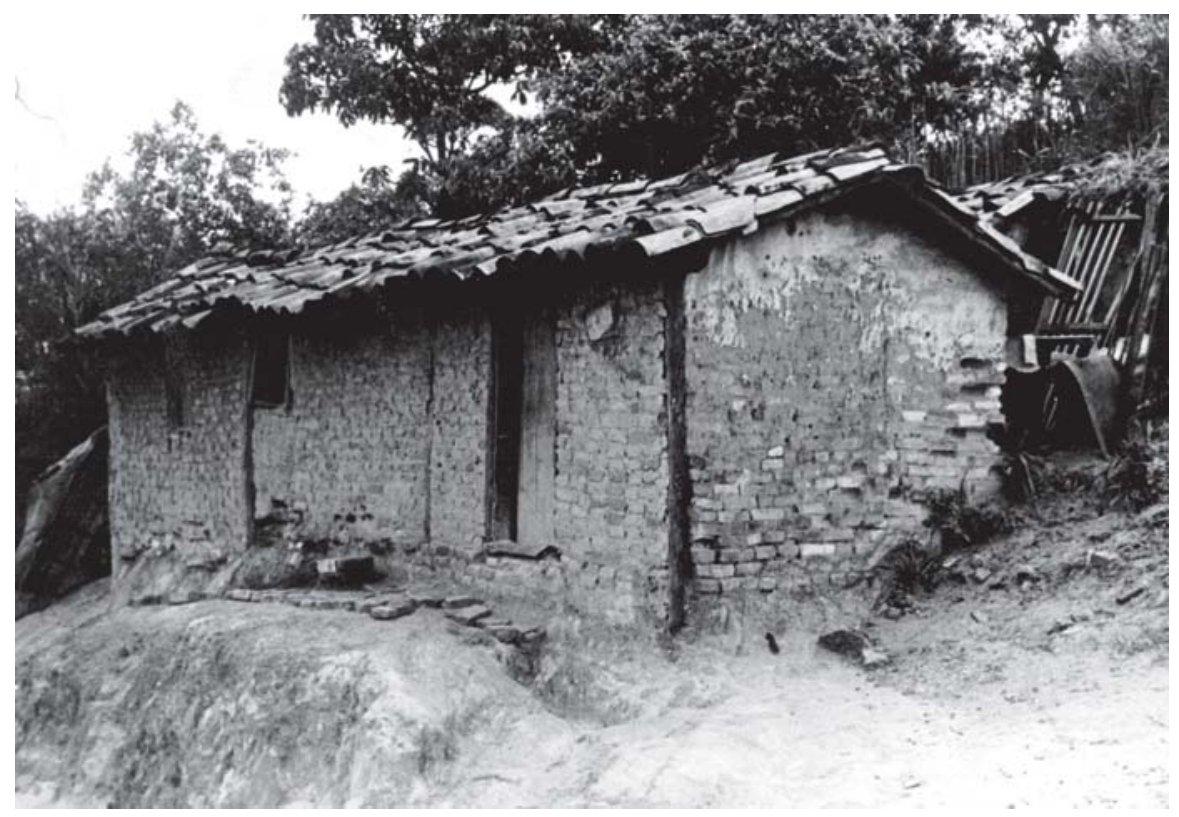

FIGURA 15 - Vista externa de habitação da Tabatinga, como as da Figura 14, sem reboco nas paredes.

FOTO: Fernando Cabral 


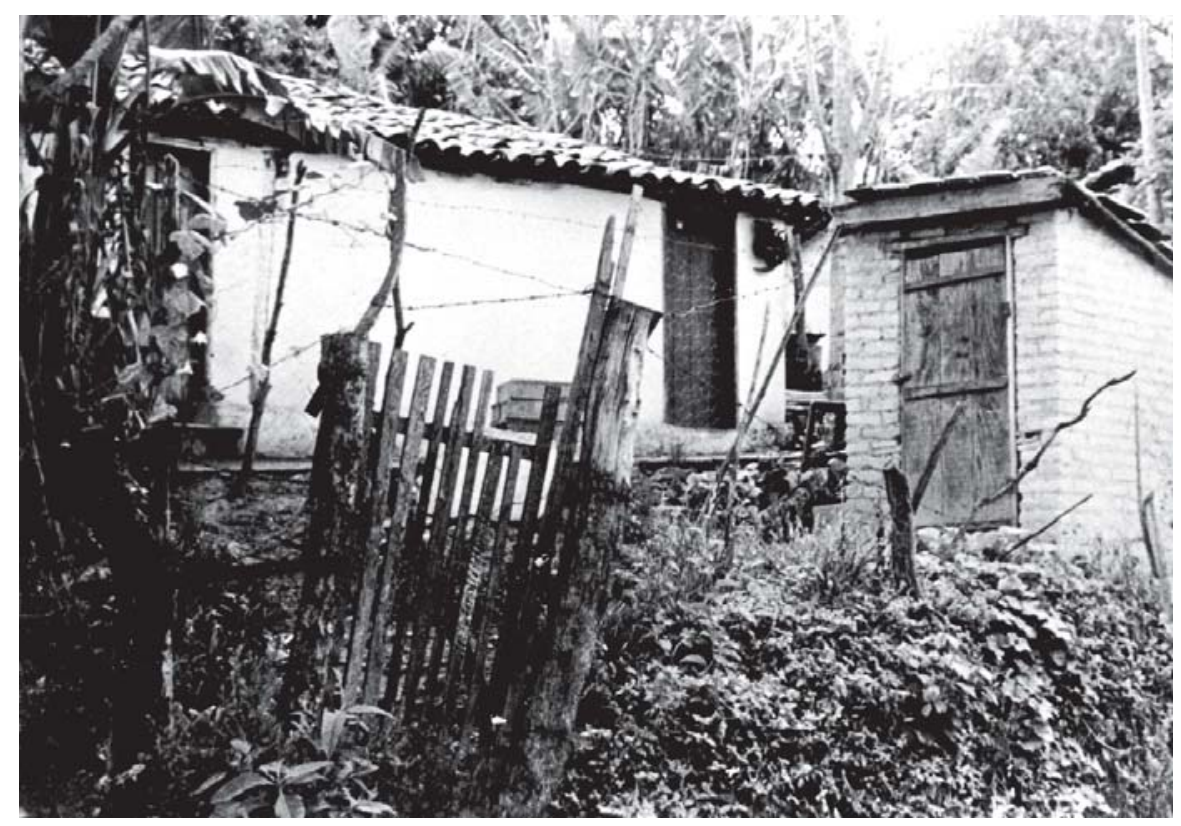

FIGURA 16 - Habitação típica da Tabatinga, com privada na parte externa. FOTO: Fernando Cabral 
Mas quem são, afinal, os negros que trouxeram à Tabatinga esse ambíguo legado de uma "língua africana" marcada pelo estigma da marginalidade? Não é fácil chegar às origens da população da Tabatinga, já que, ali, o culto à genealogia tem um lugar de pouca ou nenhuma importância na vida das pessoas. Assim, interpelados sobre seus ascendentes, os entrevistados se mostraram, na grande maioria das vezes, lacônicos, fornecendo informações incompletas e imprecisas. Juntando, porém, dados colhidos em depoimentos diversos, foi possível identificar duas famílias ligadas à introdução da Língua do Negro da Costa, bem como reconstituir suas árvores genealógicas até a quarta geração, embora com uma certa oscilação nos nomes, inevitável diante da ausência de documentação pessoal que caracteriza a comunidade.

A primeira figura que aparece nas entrevistas como um dos introdutores da Língua do Negro da Costa em Bom Despacho é o negro Dicoberto - Dagoberto Tomás Pinto da Fonseca (ou simplesmente Dagoberto Tomás Pinto) —, apontado como ex-escravo e famoso pelo hábito de andar montado em uma mula preta, vestindo sempre uma capa também preta. Filho de Tomás Pinto da Fonseca (ou Dagoberto Tomás Pinto) e Luíza Vieira, escravos que viveram em Santo Antônio das Pedras, ${ }^{4}$ e tendo como irmãs Afonsina, Corina, Castorina, Bárbara e Maria Tomás, Dicoberto casou-se com Ana Antônia de Jesus (ou Ana Feliciano da Costa), com quem teve oito filhos. Por ocasião da pesquisa de campo dois deles, Angélica e Jesus Pinto da Fonseca (cf. Figura 17), ainda estavam vivos e preservavam o conhecimento da Língua do Negro da Costa, aprendida com o pai. Ambos sem filhos, já com aproximadamente 50 ou 60 anos, Angélica e Jesus eram, pois, os últimos representantes da família de Dicoberto, fadada a desaparecer dentro de, no máximo, algumas décadas.

A mulher de Dicoberto, Ana Antônia de Jesus, criada na Fazenda do Sapé, um dos núcleos de escravos em Bom Despacho5 ${ }^{5}$ era filha de José Feliciano da Costa (ou João Feliciano) e Maria Angélica de Jesus. Ana teve como irmãos Antônio Feliciano e José Feliciano da Costa, que se casou com Maria Tomás, irmã de Dicoberto. Do casamento de José Feliciano e Maria Tomás nasceram Maria Feliciano, Maria Tomás e Nair Feliciano, ainda vivas. As irmãs Feliciano, ou Friciano, como são conhecidas na Tabatinga, lembram-se de ouvir o pai falando a Língua do Negro da Costa, mas não chegaram a aprendê-la, certamente

\footnotetext{
${ }^{4}$ Donde ser denominada pelo neto Luíza Vieira das Pedras.

5 Cf. Cap. III, p.39.
} 
por serem mulheres, segundo explicação fornecida por uma delas, Maria Feliciano. A elas, que, também sem filhos, vêm a ser, como os primos Jesus e Angélica, os últimos frutos da família, coube preservar outras tradições: o congado e a cestaria.

Todos os anos, durante as festas de N. Sra. do Rosário, as três irmãs saem às ruas no terno de Moçambique (ou dos Moçambiqueiros), costume no qual são acompanhadas pelos descendentes de Dicoberto. Essa ligação com os moçambiqueiros permite esboçar a hipótese de uma origem banto para a família Dicoberto/Feliciano, na medida em que consideramos os moçambiqueiros como ligados, nas origens, aos negros vindos de Moçambique, território do domínio banto.

Nas horas que sobram do trabalho de lavadeiras ou domésticas, as irmãs Feliciano se dedicam a fazer peneiras de fibra de cambaúba (Figura 18), conservando um costume desenvolvido desde a infância e que no passado, quando havia maior disponibilidade de matéria-prima, incluía também samburás feitos de palha de milho. A cestaria é apontada por africanistas como costume típico dos povos bantos, ${ }^{6}$ o que vem reforçar a hipótese acima sugerida para a origem do grupo.

A segunda figura de destaque entre os falantes mais antigos da Língua do Negro da Costa é o preto Zé Caria (ou Zacaria), já mencionado no Capítulo III deste trabalho, ${ }^{7}$ que se casou com Joaquina Caria. Desse casamento nasceu Maria Joaquina da Silva, que, tendo-se casado com o baiano João Antônio dos Santos, teve os filhos Maria Joaquina da Silva e José Antônio dos Santos — ainda vivos, conhecidos na Tabatinga como Fiotinha e Zé Baiano. Fiotinha e Zé Baiano não repetem o exemplo anterior, mas, ao contrário, garantem continuidade à família, ela com seis filhos e seis netos, ele com dois filhos e seis netos (Figuras 19 e 20).

Sobre os costumes dos Caria, sabemos que se ligam à tecelagem, e quanto às suas origens a referência é a Bahia, que nos remete já aos sudaneses, embora sem fechar a possibilidade de uma origem também banto, como a da outra família aqui estudada. Os descendentes vivos do preto Zé Caria preservam todos o conhecimento da Língua do Negro da Costa, mas não identificamos nenhum outro traço que pudesse relacioná-los a um grupo cultural africano determinado.

\footnotetext{
${ }^{6}$ Cf., por exemplo: RAMOS. As culturas negras no novo mundo, p.234.

${ }^{7}$ Cf. p. 40 .
} 
Além dessas duas famílias, associam-se à introdução da Língua do Negro da Costa em Bom Despacho os nomes de Camargo, Miguel Pontes e Amadeu Pontes, os dois últimos pai e avô de Dunga, congadeiro já mencionado no Capítulo III deste trabalho. ${ }^{8}$ Quanto a Camargo, é referido como dono de um bar onde, na Tabatinga, se reuniam os primeiros falantes, entre os quais o já citado Dicoberto, Miguel e Gustavo, a respeito de quem não há outras referências.

Ainda com relação à origem dos negros da Tabatinga, temos a favor da hipótese banto o depoimento do falante Bacará - branco dos mais respeitados como grande conhecedor da língua e um dos poucos a fazer referência à África como pátria da Língua do Negro da Costa. Segundo ele, a língua teria vindo de Angola. Também de Angola certamente vieram, a julgar pelos nomes, os pretos Rosa Angolla, escrava do cap. Francisco de Araújo, e Luiz Angolla, escravo de Domingos Luiz de Oliveira, sepultados no adro da então capela de Bom Despacho, a primeira em 20/08/1777 e o segundo em 26/07/1778, de acordo com o que está na História de Bom Despacho, de Laércio Rodrigues. ${ }^{9}$ Mas a história do negro em Bom Despacho ainda está por ser escrita.

${ }^{8}$ Cf. p. 48.

${ }^{9}$ Cf. RODRIGUES. História de Bom Despacho, p.53-54. 


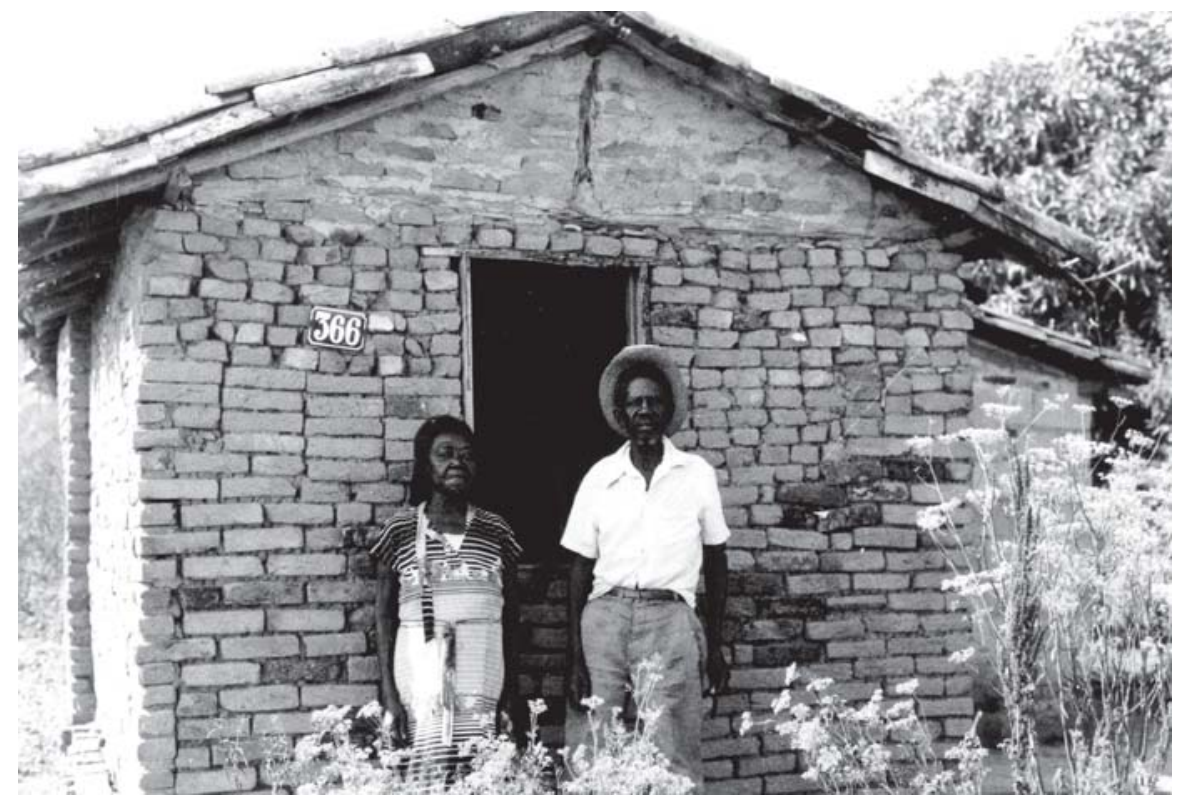

FIGURA 17 - Jesus e Angélica, os últimos descendentes de Dagoberto Tomás Pinto - o Dicoberto.

FOTO: Élida Queiroz de Araújo 


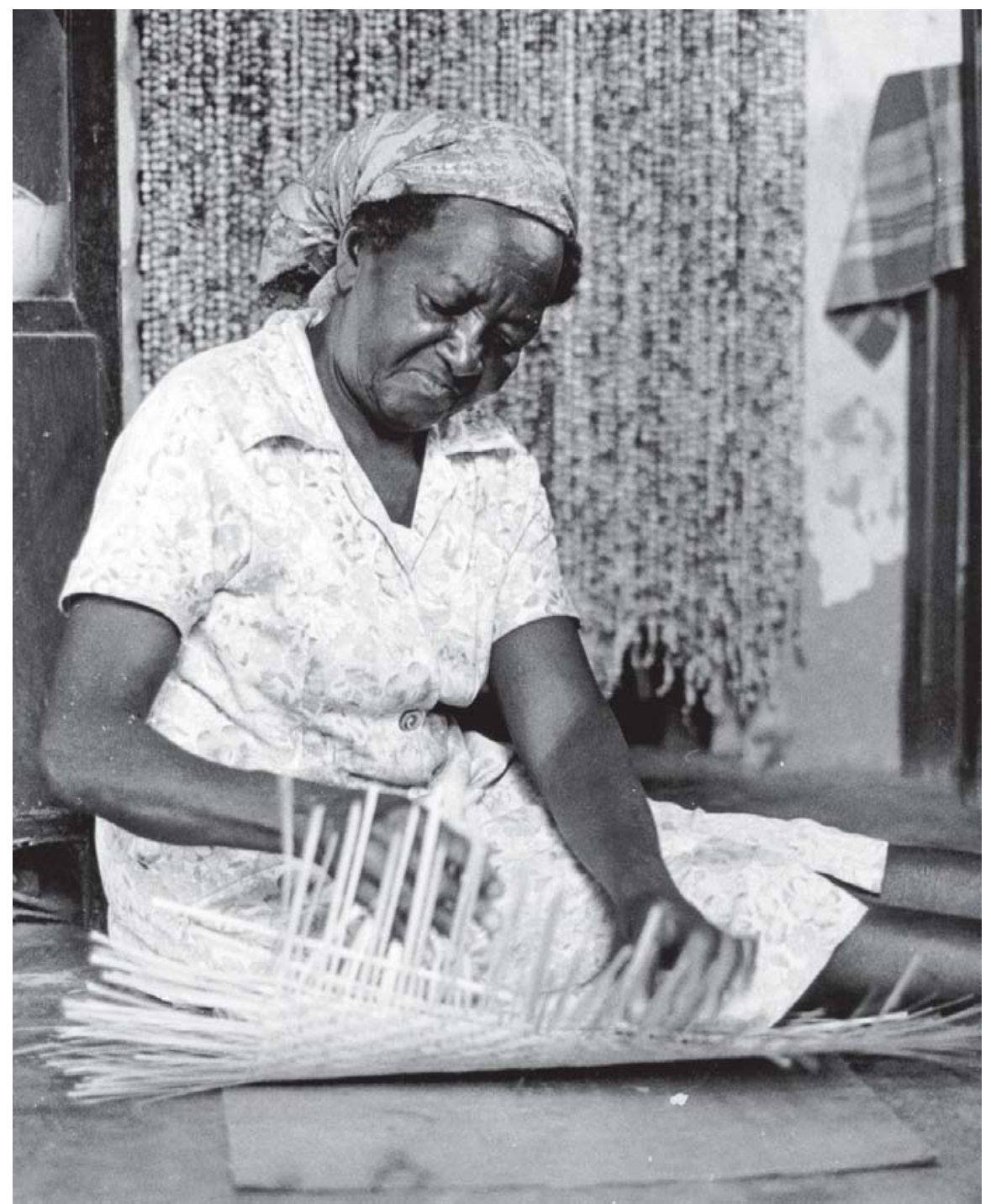

FIGURA 18 - Maria Feliciano - mantendo a tradição da cestaria, artesanato banto. FOTO: Élida Queiroz de Araújo 


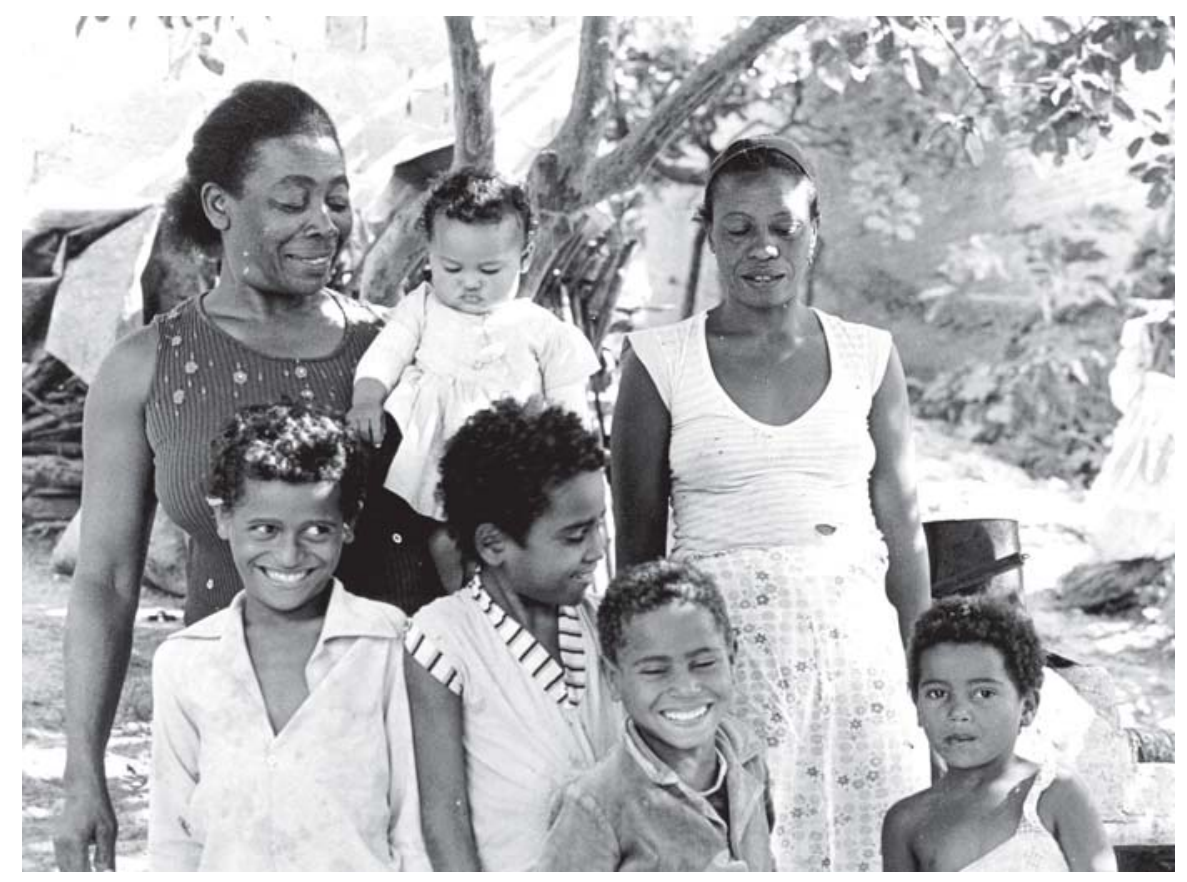

FIGURA 19 - Os descendentes de Zé Caria (ou Zacaria) — Maria Joaquina da Silva, a Fiotinha (no alto, à esquerda), com uma filha e netos. FOTO: Élida Queiroz de Araújo 


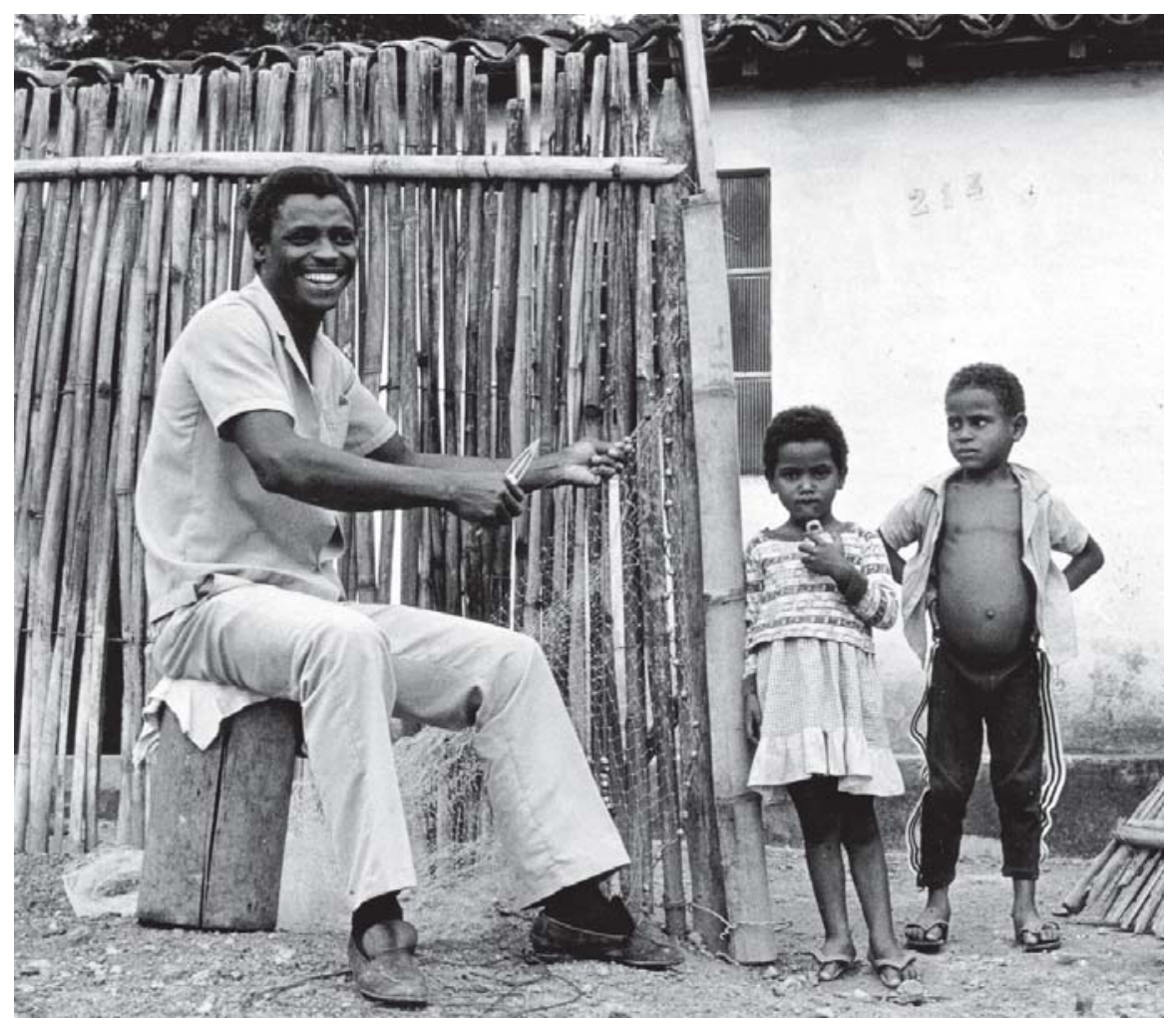

FIGURA 20 - Os descendentes de Zé Caria (ou Zacaria) — José Antônio da Silva, filho da Fiotinha, e filhos. FOTO: Élida Queiroz de Araújo 


\section{O SEGREDO DAS PALAVRAS}

Camberela pode sê de porco o de vaca, qualqué uma. Seno camberela, seno carne... O arroz, vô dizê pa sinhora o arroz, pedi a sinhora assim um prato de arroz. Aí eu falo com a sinhora: o cureia. Sinhora me dá o cureia, que nóis qué amoçá camberela e missango, qué dizê que é o arroz e carne.

Jesus Pinto

Interpelado sobre a origem de seu conhecimento da Língua do Negro da Costa, o falante Jesus Pinto respondeu tê-la aprendido, juntamente com a irmã Angélica, n'O Livro de Violeta. Como se sabe, trata-se de um manual de leitura para o segundo ano primário, largamente utilizado em Minas há algumas décadas, o que se pode deduzir do seu elevado número de edições. ${ }^{1}$ Não sendo, é claro, uma gramática da Língua do Negro da Costa, O Livro de Violeta apresenta, no entanto, particularidades que de certo modo explicam a relação estabelecida por Jesus Pinto: as histórias são narradas por uma mãe preta, "uma velha empregada da casa, (...) que criou Violeta" (Figura 21), e numa delas — "O Beija-Flor" - aparece uma cantiga com palavras de base africana já modificadas, que reproduzimos a seguir.

Ingerê

Como gambê

Como na chácara

Não há:

Ingerê

Ingerê

Crá, Crá. ${ }^{2}$

\footnotetext{
${ }^{1}$ Consultamos a $38^{a}$ edição, de 1959 (LÚCIO, FROTA. O livro de Violeta.) A primeira edição (ainda sem a colaboração de Zilah Frota) é de 1937.
}

${ }^{2}$ LÚCIO, FROTA. O livro de Violeta, p.54-55. 


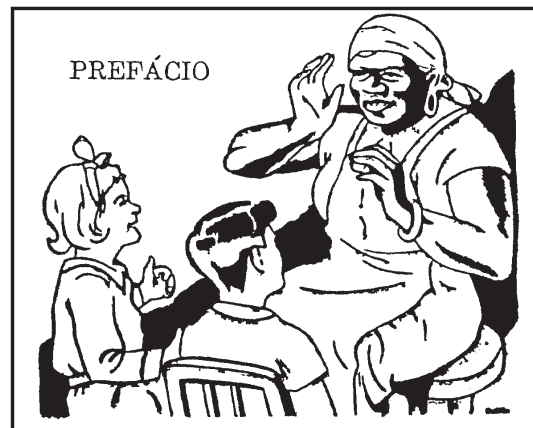

Caros colegas

Este livrinho é feito especialmente para os meninos do $2^{\circ}$ ano de todo o Brasil.

Queremos contar a vocês alguma coisa sôbre o nosso livro. Ele tem histórias bonitas, engraçadas e bôas - de Jesus, de animais, de índios e sacís. Foi escrito para uma menina do $2 .^{\circ}$ ano, como todos nós, chamada Violeta, que gosta muito de casos engraçados como "No Inferno", "Macacos ensinados" e outros.

Vocês pensam que tem só histórias? Não !... poesias também.

E a Mãe Preta? Vocês sabem o que é uma Mãe Preta? Não estranhem o nome. E' uma preta velha empregada da casa, que a gente estima muito e que sabe um "horror" de histórias interessantes. Foi ela que criou Violeta.

Nós ajudamos a fazer êste livro. Ajudamos assim: Dona Zilah lia as histórias que João Lúcio inventou, nós dizíamos os pedaços difíceis e ela consertava.

Nós aconselhamos êste livro a todos os meninos do $2 .^{\circ}$ ano.

Vocês hão-de gostar muito dêle.

2. ano de 1937 das Classes Primárias Anexas d Escola de Aper/eiçoamento.

FIGURA 21 - O livro de Violeta: a Mãe Preta conta "casos engraçados" aos meninos do Brasil. 
Uma dessas palavras, gambê, que, numa leitura sincrônica da cantiga, aparece como recurso mnemônico utilizado para facilitar a memorização de ingerê, pode muito facilmente ser relacionada à sua correspondente na Língua do Negro da Costa, gombê 'boi', 'vaca', já que entre as duas formas a diferença está apenas na vogal da sílaba átona, e essa diferença desaparece no diminutivo gambezim 'bezerro', registrado em Bom Despacho. O significado não é fornecido explicitamente pela cantiga, mas supomos que coincida com o da forma encontrada na Língua do Negro da Costa suposição que se funda em diversos outros registros do vocábulo. ${ }^{3}$

Dessa forma, não nos parece imotivada a relação estabelecida por Jesus entre a Língua do Negro da Costa e O Livro de Violeta, embora, evidentemente, não se possa aceitar a sua afirmação de que aprendeu a língua através desse manual. Acrescentaríamos aqui a importância da atitude de Jesus enquanto manifestação de um interesse em atribuir à Língua do Negro da Costa o prestígio de língua escrita e, mais, ensinada na escola, o que a colocaria no mesmo nível da língua dos brancos, o português.

Em realidade, a transmissão da Língua do Negro da Costa não se dá na escola nem na família, mas entre amigos, numa faixa etária entre 11 e 20 anos (cf. Tabelas 15 e 16), ou seja, quando o indivíduo já domina totalmente a língua materna e começa a intensificar as relações fora do lar, nos bares, nas festas. Com efeito, é nessas situações de lazer, predominantemente, que a Língua do Negro da Costa é utilizada, como se vê na Tabela 17.

${ }^{3}$ Encontramos ngombe, ongombe (MACHADO FILHO. O negro e o garimpo em Minas Gerais, p.122, 123); orongoma, orongombe (DORNAS FILHO. Revista do Arquivo Municipal, p.148); ongómbi (GNERRE et al. Cafundó: creole(?) death or change? p.2); ngombe (VOGT, GNerRe. Estudos Linguísticos, p.13; VOGT et al. Punto de Vista, p.30). Em todos esses registros o significado é 'boi'; apenas no Cafundó (duas últimas variantes) o vocábulo pode significar também 'cavalo' e 'burro'. CANNECATTIM, em Collecção de observações grammaticaes sobre a lingua bunda ou angolense, também registra para o bundo as formas ngombe e ngómbi (p.8 e 168) e para o conguês, ngumbe (p.168), todas com o significado de 'boi'. 
TABELA 15

Distribuição dos falantes da LNC segundo a pessoa com quem a aprenderam

\begin{tabular}{l|c|c}
\hline FALANTES & Números absolutos* & $\%$ \\
\hline Com amigos & 103 & 90,4 \\
\hline Com colegas de trabalho & 20 & 17,5 \\
\hline Com parentes & 12 & 10,5 \\
\hline
\end{tabular}

FONTE: Pesquisa de campo - julho de 1981.

* O total de informantes aqui é 114. Esse número não coincide com a soma da primeira coluna da tabela pelo fato de um mesmo falante poder ter sido computado até três vezes, na medida em que tivesse aprendido a Língua do Negro da Costa com amigos, colegas de trabalho e parentes.

TABELA 16

Distribuição dos falantes da LNC segundo a idade com que a aprenderam

\begin{tabular}{|c|c|c|}
\hline IDADE $\quad$ FALANTES & Números absolutos* & $\%$ \\
\hline $0-10^{*}$ & 39 & 34,2 \\
\hline $11-20$ & 57 & 50,0 \\
\hline $21-30$ & 05 & 4,4 \\
\hline $31-40$ & 05 & 4,4 \\
\hline $41-50$ & 01 & 0,9 \\
\hline Não informada & 07 & 6,1 \\
\hline Total & 114 & 100,0 \\
\hline
\end{tabular}

FONTE: Pesquisa de campo - julho de 1981.

* Mais exatamente entre 5 e 10. 


\section{TABELA 17}

Distribuição dos falantes da LNC segundo as situações de fala em que predominantemente a usam

\begin{tabular}{l|c|c}
\hline $\begin{array}{l}\text { SITUAÇÃO } \\
\text { FE FALA }\end{array}$ & Números absolutos* & $\%$ \\
\hline Com amigos & 106 & 93,0 \\
\hline Em bares e festas & 81 & 71,0 \\
\hline Em família & 52 & 45,6 \\
\hline No trabalho & 42 & 36,8 \\
\hline
\end{tabular}

FONTE: Pesquisa de campo - julho de 1981.

* O total de informantes aqui é 114. Esse número não coincide com a soma da primeira coluna da tabela pelo fato de um mesmo falante poder ter sido computado mais de uma vez, na medida em que utilizasse a língua predominante em mais de uma situação.

\section{ASPECTOS GERAIS DA ESTRUTURA MORFO-SINTÁTICA}

A análise das gravações mostrou ser a estrutura gramatical da Língua do Negro da Costa integralmente tomada ao português. Evidentemente, trata-se de uma variedade regional do português, que, como já observamos aqui, em muito se confunde com aquela descrita por Amadeu Amaral em $O$ dialeto caipira. Embora tenha sido elaborada há mais de 60 anos (a primeira edição é de 1920), e se restrinja ao dialeto da zona rural do Estado de São Paulo, essa descrição é a que nos parece mais adequada para o conhecimento do português que serve de base à Língua do Negro da Costa. A propósito, vale lembrar, com Serafim da Silva Neto, que "a grande maioria dos fatos que caracterizam os nossos falares regionais tem âmbito panbrasileiro". ${ }^{4}$

Constituída fundamentalmente de léxico "africano" e gramática portuguesa, a Língua do Negro da Costa repete essa estrutura no nível da formação vocabular: os semantemas são quase todos

\footnotetext{
${ }^{4}$ Cf., por exemplo: CASTRO. Educação, p.49-64.
} 
"africanos", ao passo que os morfemas, tanto os derivacionais quanto os flexionais, são todos portugueses. Evidentemente, uma análise diacrônica identificaria em diversos vocábulos da Língua do Negro da Costa prefixos de origem africana, como, por exemplo, o ca-de camona 'criança', que encontramos registrado por Frei Bernardo M. de Cannecattim, ${ }^{5}$ em sua gramática da língua bunda, como prefixo diminutivo. O exemplo dado por Cannecattim é exatamente camõna 'o filho pequeno', diminutivo derivado de monã 'filho'. Do ponto de vista sincrônico, entretanto, camona é uma unidade mórfica indivisível, à qual se podem acrescentar morfemas portugueses, na formação de novos vocábulos. O diminutivo camonim 'criancinha', formado com o acréscimo de - im, sufixo diminutivo do português popular, exemplifica bem que, na Língua do Negro da Costa, o $c a$ - já perdeu seu valor original. O mesmo fato foi registrado por Yeda P. de Castro na língua dos cultos afro-brasileiros, na Bahia: "(...) os nomes bantos, todos compostos de um conjunto prefixal, de um radical e eventualmente de um sufixo, vêem seus limites morfológicos desaparecerem e são reinterpretados como formados unicamente de um radical enlarguecido, indecomponível, como kà.n.dómb.íd.é candomblé, candomblezeiro; mà.kóm.á macumba, macumbeiro." ${ }^{6}$

Na Língua do Negro da Costa, o processo de formação vocabular mais produtivo, se não exclusivo, é a derivação sufixal. Em nossos registros, ocorreram os seguintes sufixos:

1) $-a$, variante popular do português padrão -ar, formador de infinitivos da $1^{a}$ conjugação verbal, como em olhar, pop. olhá, de olho -

LNC marcanjá 'fumar', de marcanjo 'cigarro'; injirá 'ir', 'andar', de injira 'caminho';

2) $-d o(-a)$, formador de particípios e, eventualmente, de adjetivos, a partir de infinitivos verbais, como no português olhado, de olhar -

LNC cassucarado 'casado', de cassucará 'casar';

${ }^{5}$ Cf. CANNECATTIM. Collecção de observações grammaticaes sobre a língua bunda ou angolense, p.166.

${ }^{6}$ CASTRO. Níveis sociolingüísticos da integração de influências africanas no português, p.13. 
3) - $d a$, formador de substantivos que indicam ação, a partir de infinitivos verbais, como no português (uma) olhada, de olhar $-^{7}$

LNC tipurada 'olhada', de tipurá 'olhar';

4) -dô, variante popular do português padrão -dor, formador de substantivos que indicam agente, a partir de infinitivos verbais, como no português cantador, pop. cantadô, de cantar -

LNC curimbadô 'trabalhador', de curimbá 'trabalhar';

5) -udo (-a), formador de adjetivos que indicam abundância, a partir de substantivos, como no português carnudo, de carne LNC cambereluda 'boazuda', de camberela 'carne'.

Tendo em vista a coerência do sistema derivacional da Língua do Negro da Costa, atribuímos ao sufixo verbal $-a ́$, como a todos os outros, uma origem portuguesa. Levamos em conta ainda que o sufixo -ar (popular $-\hat{a}$ ) marca precisamente a conjugação mais numerosa e produtiva do sistema verbal português. Entretanto, neste caso, a explicação por uma herança africana seria igualmente possível, já que, nas línguas do grupo banto, o morfema de infinitivo da maior parte dos verbos é também $-a{ }^{8}$ Provavelmente, essa coincidência favoreceu a constituição de uma única classe de infinitivos verbais na Língua do Negro da Costa.

Ocorreram ainda, e com maior produtividade, os seguintes sufixos formadores de diminutivos e aumentativos:

1) Diminutivos

1.1) -inho(-a), que ocorre depois de consoante, em palavras que, no processo de derivação, perdem a vogal átona final, como no português padrão menininho, de menino -

LNC camoninho 'criancinha', de camona 'criança';

avurinha 'bonitinho (-a)', de avura 'bonito';

cuxipinha 'bocetinha' de cuxipa 'boceta';

1.2) -im, variante popular do português padrão -inho (-a), que ocorre também depois de consoante, em palavras que, no

\footnotetext{
${ }^{7}$ Pode-se explicar essa derivação também por mudança de classe, a partir da forma feminina do particípio.

${ }^{8}$ CASTRO. Níveis sociolingüísticos da integração de influências africanas no português, p.13; LANG. Ensaios de gramática nyaneka, p.58.
} 
processo de derivação, perdem a vogal átona final, como no português pop. meninim, de menino -

LNC cuetim 'menininho', de cuete 'homem';

marcanjim 'cigarrinho', de marcanjo 'cigarro';

1.3) -zinho(-a), que ocorre depois de vogal, como no português padrão cafezinho, de café, e falazinha, de fala -

LNC marcanjozinho 'cigarrinho', de marcanjo 'cigarro';

candomborazinha 'frango', de candombora 'galinha';

ingurazinha 'dinheirinho', de ingura 'dinheiro';

1.4) -zim, variante popular do português padrão -zinho(-a), que ocorre depois de vogal, como no português popular cafezim, de café, e corgozim, de córrego -

LNC oranjezim 'cabelinho', de oranjê 'cabelo';

conjolozim 'casinha', de conjolo 'casa';

ocaizim 'menina', de ocaia 'mulher';

1.5) -inzim, diminutivo duplo, formado pela associação dos sufixos citados em 1.2 e 1.4, como no português popular matinzim, de mato -

LNC aiaquinzim 'queijinho', de aiaque 'queijo';

1.6) -ico(-a), como no português burrico, de burro -

LNC cuetitico 'menininho', de cuete 'homem'.

Releva notar que -im e -zim são os sufixos mais freqüentes, ocorrendo indistintamente em vocábulos masculinos e femininos, como se vê nos exemplos citados acima, o cuetim 'o menino' e a ocaizim 'a menina'.

2) Aumentativos

2.1) -ão, que ocorre depois de consoante, em palavras que, no processo de derivação, perdem a vogal átona final, como no português grandão, de grande -

LNC tibangão 'bobão', de tibanga 'bobo';

camonão 'meninão', de camona 'criança';

2.2) -aço, que ocorre depois de consoante, em palavras que, no processo de derivação, perdem a vogal átona final, como no português copaço, de copo -

LNC avuraço 'grandão', de avura 'grande'; 
2.3) -zão, que ocorre depois de vogal tônica, como no português pezão, de pé -

LNC tuezão 'cabeção', de tué 'cabeça'.

Não se registrou nenhum caso de derivação prefixal, tampouco de composição vocabular. Além dos derivados sufixais, o que há são perífrases, reunião de dois ou mais vocábulos para constituir uma unidade significativa em geral ausente no léxico. Na Língua do Negro da Costa, língua de vocabulário extremamente reduzido, a perífrase funciona como a mais importante fonte geradora de significantes novos, exigidos a todo momento para a comunicação. Os exemplos são inúmeros, mas, por escaparem à sistematização gramatical, nos limitaremos aqui a registrar o fato, que será tratrado no Capítulo V e exaustivamente exemplificado no Capítulo VII.

Apresentados os fatos mais relevantes da estrutura das palavras "africanas" da Língua do Negro da Costa, passemos a algumas observações relativas ao seu comportamento morfo-sintático. Essas observações se restringirão aos verbos, pronomes e nomes, já que os vocábulos relacionais, na Língua do Negro da Costa, como tudo que diz respeito à sua estrutura gramatical, são tomados ao português - escapando, assim, ao objeto do nosso trabalho.

Diferentemente da língua portuguesa, em que os verbos se agrupam em três conjugações, a Língua do Negro da Costa enquadra todos os seus verbos em apenas uma conjugação, caracterizada pelo morfema -á do infinitivo, como já foi assinalado anteriormente: tipurá 'olhar', 'entender'; injurá 'ir', 'andar', 'correr'; curimbá 'trabalhar'; catiolá 'roubar' etc. As categorias verbais são as do português regional, repetindo-se nelas a tendência à redução, já observada quanto ao número das conjugações. Assim, verifica-se a falta de certos tempos, como o presente do subjuntivo, que é suprido pelo presente do indicativo, e o futuro do pretérito, que é suprido pelo imperfeito do indicativo.

A flexão verbal de número e pessoa é radicalmente reduzida: em alguns tempos, como o presente do indicativo, há uma primeira pessoa do singular, que se opõe a todas as outras como um bloco; em outros, como o imperfeito do indicativo, as marcas de pessoa e número desapareceram totalmente. As oposições númeropessoais acabam sendo marcadas pelo pronome pessoal sujeito, tomado ao português regional. Exemplifiquemos com a conjugação de um verbo. 
Verbo tipurá 'olhar', 'ver', 'entender' etc.

Presente do indicativo

\begin{tabular}{l|l|c}
\hline \multicolumn{1}{c|}{ Pessoa } & \multicolumn{1}{|c}{ Pronome Sujeito } & Forma Verbal \\
\hline $1^{\underline{a}} \mathrm{~s}$. & eu & tipuro \\
$2^{\underline{\underline{a}}} \mathrm{~s}$. & ocê, cê, o sinhô, a sinhora & \\
$3^{\underline{a}} \mathrm{~s}$. & ele, ela & \\
$1^{\underline{a}} \mathrm{pl}$. & nóis, a gente & tipura \\
$2^{\underline{\underline{a}}} \mathrm{pl}$. & ocês, oceis, cês, ceis, os sinhô, as sinhora & \\
$3^{\underline{a}} \mathrm{pl}$. & eis, eles, eas, elas & \\
\hline
\end{tabular}

$\mathrm{Na} 1^{\mathrm{a}}$ pessoa do plural, tipura alterna com tipuramo, menos freqüente, em que se nota um resquício da flexão portuguesa.

Pretérito Perfeito do Indicativo

\begin{tabular}{|c|c|c|}
\hline Pessoa & Pronome Sujeito & Forma Verbal \\
\hline $1^{\underline{a}} s$. & $\mathrm{eu}$ & tipurei \\
\hline $2^{\underline{a}} s$. & ocê, cê, o sinhô, a sinhora & \\
\hline $3^{\underline{a}} s$. & ele, ela & \\
\hline $1^{\underline{a}} \mathrm{pl}$ & nóis, a gente & tipurô \\
\hline $2^{\mathrm{a}} \mathrm{pl}$ & ocês, oceis, cês, ceis, os sinhô, as sinhora & \\
\hline $3^{\underline{a}} \mathrm{pl}$ & eis, eles, eas, elas & \\
\hline
\end{tabular}

A forma tipurô alterna, na $1^{\text {a }}$ pessoa do plural, com tipuremo e tipuramo, e na $3^{\text {a }}$ pessoa do plural, com tipuraro, as três últimas menos freqüentes.

Pretérito Imperfeito do Indicativo

Forma única: tipurava

Pretérito Imperfeito do Subjuntivo

Forma única: tipurasse

Futuro do Subjuntivo

Forma única: tipurá

Imperativo

Forma única: tipura 


\section{Gerúndio \\ tipurano \\ Particípio \\ tipurado \\ Infinitivo \\ tipurá}

Esse reduzido quadro flexional se completa com as formas perifrásticas, que expressam noções de tempo e aspecto, segundo o modelo do português regional. Assim temos, por exemplo: tá tipurano, tem tipurado, tava tipurano, vai tipurá, ia tipurá.

A tendência à redução das oposições número-pessoais na Língua do Negro da Costa já atinge até mesmo a oposição básica entre a $1^{\text {a }}$ pessoa do singular e as outras, em decorrência de uma forma peculiar de pronome sujeito. Por vezes, nas entrevistas, o falante usa para se referir a si mesmo expressões como o cuete aqui (lit. 'o homem aqui'), o cuete cafuvira (lit. 'O homem preto') ou simplesmente $o$ cuete (lit. 'o homem'), que levam o verbo para a $3^{\text {a }}$ pessoa, reduzindo, dessa forma, a flexão verbal ao tempo e deixando as oposições de pessoa e número a cargo do contexto. A pessoa é identificada, então, por um pronome adverbial como aqui, aí, ali, adjunto ao substantivo cuete 'homem' ou ocaia 'mulher' ou pela própria situação, nos moldes de construções portuguesas populares como o degas aqui ou o papai aqui.

Assim, a frase O cuete cafuvira num caxa ingura, que literalmente significa 'O homem preto não tem dinheiro', pode significar, dita por um negro, 'Eu não tenho dinheiro'. Para que se efetue a comunicação na Língua do Negro da Costa, é preciso que o interlocutor esteja completamente integrado à situação, ou, para usar uma expressão da língua, tem que tipurá a cena. Veja-se, a título de ilustração, a seguinte frase, de uma mulher da Tabatinga, em entrevista: Ocaia tem só esse (camonim) aqui, que eu num sô sucarada não, sabe? (lit. 'Mulher tem só essa (criança) aqui, que eu num sô casada não, sabe?'). O uso do eu na segunda oração não deixa dúvidas quanto ao uso de ocaia na primeira, referindo-se à primeira pessoa do discurso.

Como já se observou para os verbos, a flexão nominal é também bastante simplificada na Língua do Negro da Costa. Os morfemas de gênero e número são os mesmos do português ( $-a$ para o feminino e - $s$ para o plural), porém seu uso apresenta algumas peculiaridades. 
A flexão de número nunca se marca no substantivo, mas sim no primeiro de seus determinantes (artigo, demonstrativo, possessivo etc.). Assim temos, por exemplo:

Singular

o cambuá
Plural

os cambuá
Tradução

$\mathrm{o}(\mathrm{s})$ cachorro(s)

meu cambuá uarrufo meus cambuá uarrufo meu(s) cachorro(s) bravo(s)

Quanto ao gênero, marca-se não apenas no primeiro determinante, mas em todos eles, em concordância com o gênero do substantivo:

uma ocaia cassucarada 'uma mulher casada'

Os nomes substantivos que designam seres inanimados não possuem gênero fixo, sendo possível ouvir-se de um mesmo falante:

a cumbara catita ou o cumbara catito 'a cidade pequena'

A concordância é variável, podendo fazer-se:

1) com o gênero da palavra portuguesa correspondente, como em Num caxo ingura nenbum 'Num tenho dinhero nenhum';

2) com a vogal final do vocábulo "africano", interpretada como marca de gênero, como em Num caxo inguna nenhuma 'Num tenho dinhero nenhum'.

A distinção de sexo, para os nomes substantivos que designam seres animados, marca-se de dois modos:

1) pela heteronímia, em um único caso cuete 'homem', ocaia 'mulher';

2) pela justaposição das palavras cuete, para o sexo masculino, e ocaia, para o feminino cuete meu tata 'pai', ocaia meu tata 'mãe' moná cuete 'menino', moná ocaia 'menina' gombé cuete 'boi', gombê ocaia 'vaca'

Segundo Cannecattim, "é próprio dos nomes abundos serem todos promíscuos ou epicenos (...) e por isso dependerem de outro que signifique (...) o sexo a que pertencem". ${ }^{9}$ Estudos recentes

${ }^{9}$ CANNECATTIM. Collecção de observações grammaticaes sobre a lingua bunda ou angolense, p.166. 
comprovam que na maioria das línguas negro-africanas, entre elas o quimbundo, a distinção entre masculino e feminino não é utilizada. ${ }^{10}$ Entretanto, encontramos também no português esse mesmo procedimento, tanto com a função de distinguir o sexo, por exemplo, em jacaré macho, jacaré fêmea, quanto com o objetivo de reforçar essa distinção já marcada por outro recurso, como ocorre na linguagem popular em menino home, menina muié.

Finalmente, queremos observar que, para além dos fatos registrados até aqui, a Língua do Negro da Costa partilha com o dialeto caipira uma série de outras características, como:

1) utilização do pronome reto como objeto direto ou mesmo ausência de objeto explícito;

2) uso do verbo ter como impessoal;

3) extrema redução dos verbos pronominais;

4) uso exclusivo do que como pronome relativo.

Vale reiterar, enfim, que todos os instrumentos gramaticais na Língua do Negro da Costa são portugueses, não se tendo verificado, no nível das relações sintáticas, nenhum fato que chamasse a atenção, como podendo significar resquício de gramática africana.

\section{ASPECTOS GERAIS DA CONSTITUIÇÃO DO LÉXICO}

O léxico da Língua do Negro da Costa é constituído, fundamentalmente, de:

1) vocábulos de provável origem africana, que se aproximam de formas já registradas por estudiosos das línguas africanas no Brasil;

2) vocábulos formados a partir de palavras "africanas" acrescidas de sufixo português;

3) criações lexicais que se podem explicar pela onomatopéia;

4) palavras de provável origem portuguesa, que se aproximam de vocábulos dicionarizados;

5) palavras portuguesas correntes na região ou mesmo fora dela, no Brasil.

${ }^{10}$ Cf. BONVINI. Faits des Langues, p.77. 
No primeiro caso está talvez a maior parte do vocabulário da Língua do Negro da Costa: cuete 'homem', ocaia 'mulher', imbuete 'pau', curimba 'trabalho', conjolo 'casa', moná 'filho', cafuvira 'preto' etc. No segundo caso encontramos, por exemplo, curimbadô 'trabalhador', derivado de curimba 'trabalho'; cambereluda 'boazuda', de camberela 'carne'; e sobretudo aumentativos e diminutivos, como timbangão 'bobão', de timbanga 'bobo', e cuetim 'menino', de cuete 'homem'. No terceiro, registraram-se apenas dois itens: xapixape 'comida' e tiproque 'sapato'. No quarto caso, encontram-se palavras como cambóia 'trem', provavelmente uma variante do português lusitano combóio 'trem'; erpido 'pênis', de uso restrito a contextos de doença venérea (nos demais contextos a palavra usada é imbuete), que sugere uma derivação do português herpes 'dermatose contagiosa'; e ainda isquife 'cama', que pode ser o resultado de uma mudança semântica do português esquife 'caixão'. No quinto caso, estão palavras que complementam o restrito vocabulário "africano" da Língua do Negro da Costa, quando a situação o exige, como, por exemplo, os nomes das cores (à exceção de 'preto' e 'branco', que contam com denominações "africanas") e a quase totalidade dos nomes de animais selvagens.

Trataremos, neste capítulo, apenas dos quatro primeiros tipos de vocábulos, ou seja, da parte do léxico que distingue a Língua do Negro da Costa do português falado normalmente pela comunidade em estudo. Sendo esses vocábulos identificados por diversos falantes como africanos, assim serão tratados também aqui neste trabalho, embora grafando-se a palavra sempre entre aspas, já que não chegamos a definir a etimologia dos vocábulos da Língua do Negro da Costa, nem foi esse nosso objetivo.

Passemos agora às observações relativas aos campos semânticos pelos quais se distribuem os vocábulos e perífrases da Língua do Negro da Costa, que nos dão, em última análise, informações preciosas sobre a vida e a visão de mundo de seus falantes.

O campo "Alimentação" vem a ser um dos mais ricos. Nele estão, por exemplo, os vocábulos ou perífrases relativos à flora, que se referem todos a plantas comestíveis: massarundá 'banana', tiporê 'laranja', cajuvira 'café', ${ }^{11}$ vianjê 'cana', assangue 'arroz', tipoque 'feijão', pungue 'milho', matambu 'mandioca', arumute 'abóbora'. Além dos vegetais - frutas, cereais e legumes —, esse campo inclui alimentos de origem animal - como camberela

${ }^{11}$ Observe-se a paronímia com cafuvira 'preto'. 
'carne', mavera 'leite', aiaque 'queijo' entre outros — e também massas como caviconve 'pão' e biguibote 'macarrão'. Os temperos registrados são apenas dois: mongo 'sal' e uique 'açúcar'. Há ainda, no campo "Alimentação", produtos como pó de matambu 'farinha de mandioca' (lit. 'pó de mandioca') e pó de pungue (lit. 'pó de milho'), que pode significar 'farinha de milho' ou 'fubá'. Como termos genéricos foram registrados cureio, bangerê e xapixape 'comida'.

A natureza está bem representada na Língua do Negro da Costa, o que certamente se explica pela origem rural dos primeiros falantes. Encontramos, nesse campo semântico, os seguintes vocábulos: undara 'fogo', omenha 'água', imbera 'chuva', fute 'céu', sengue 'mato', imbuete 'madeira', oteque 'noite', bambi 'frio', cumba e unde 'sol'. A lua é representada pelas perífrases cumba do oteque (lit. 'sol da noite') e cumba do bambi (lit. 'sol do frio'). A terra confunde-se com o trabalho - curimba - o que ainda hoje se justifica, pois é na terra, como lavradores, que trabalha a maior parte dos atuais falantes da Língua do Negro da Costa. ${ }^{12}$

$\mathrm{Na}$ fauna predominam os animais domésticos: cangura 'porco', cambuá 'cachorro', mingüée 'gato', candombora 'galinha', entre outros. Qualquer animal que se preste à montaria é orongó. O significante gombê designa também vários animais, como o boi, o carneiro ou cabrito. Os animais selvagens que aparecem nas entrevistas, à exceção de cobra - imbuta - , são nomeados com perífrases formadas a partir de nomes de animais domésticos, aos quais se junta a expressão do sengue 'do mato'. Veja-se, a propósito, o seguinte trecho de entrevista:

Às veiz nóis lá vamo assim, nóis vê um rastro, fala assim, ó: - Tem um mingüé por aí. É de conjolo ô é de sengue? Não, é de sengue. Pode ficá com o tué uarrubo e os tiparo arriba porque o negócio aqui num tá brincadera não.

(Às veiz nóis lávamo assim, nóis vê um rastro, fala assim, ó: — Tem um gato por aí. É gato ô é onça? Não, é onça. Pode prestá atenção e tomá cuidado porque o negócio aqui num tá brincadeira não.)

As relações de parentesco, no vocabulário "africano", limitam-se ao primeiro grau: ocaia meu tata 'mãe' (lit. 'mulher meu genitor'), cuete meu tata 'pai' (lit. 'homem meu genitor'), moná 'filho' e imbanje

${ }^{12}$ DORNAS FILHO. Revista do Arquivo Municipal, p.148-149; MACHADO FILHO. O negro e o garimpo em Minas Gerais, p.124. 
'irmão'. Para 'marido' e 'mulher' são utilizadas, respectivamente, as perífrases cuete da ocaia (lit. 'homem da mulher') e ocaia do cuete (lit. 'mulher do homem'). Parece não haver vocábulo para 'nascimento', mas há para 'casamento' - cassucara —, para 'morte' - conjema - e para 'doença' corvera.

No campo "Vestuário", a Língua do Negro da Costa possui uma palavra para designar roupa em geral - urunanga - e duas para calçado - tiproque e urufaco. Além dessas e das perífrases que se formam com a primeira para as necessidades de especialização do significado, como, por exemplo, urunanga catita 'calcinha', registrou-se apenas cavu 'paletó' e coreã 'chapéu'. Para 'chapéu' há ainda a perífrase tipomo do tué (lit. 'chapéu da cabeça'), cujo primeiro elemento tipomo, não apareceu isoladamente em nossos registros. Encontramos, no entanto, em João Dornas Filho, as formas tipungo e pungo e em Aires da Mata Machado, quipungo, exatamente como 'chapéu'.

A julgar pelo vocabulário levantado no campo "Lazer", as diversões dos falantes da Língua do Negro da Costa concentram-se nos bares, onde eles conversam na língua, tomam matuaba 'cachaça' ou grozope 'cerveja' e fumam um marcanjo 'cigarro'. Mas há também a possibilidade de rastá o longado 'dançar' ( lit. 'arrastar o rebolado') ao som de um imbanjeco, que pode ser 'qualquer instrumento musical'.

No domínio da religião, tudo é muito simplificado: há Deus e o padre, que se confundem numa só palavra - granjão, sendo que o segundo pode também ser designado por inganga. E há a igreja - o conjolo de granjão (lit. 'casa de Deus'). Não se registrou nenhum termo "africano" para designar o diabo ou qualquer outra entidade ligada a cultos religiosos, o que com certeza está relacionado à dominação exercida pelos brancos sobre os negros também no âmbito da religião.

$\mathrm{Na}$ área dos transportes, há o vocábulo orum, de significação genérica - 'máquina', 'carro' —, que dá origem a diversas perífrases, como orum avura 'caminhão' (lit. 'carro grande'), orum catito 'automóvel' ou 'bicicleta' (lit. 'carro pequeno'), orum de gombê 'carro de boi' e orum de orongó 'carroça' (lit. 'carro de cavalo'). Há ainda vocábulos específicos para transportes coletivos: cambanjara ônibus' e combóia 'trem'.

O corpo humano se representa em suas partes externas; tué 'cabeça', tiparo 'olho', timbuá 'mão', protiuda 'nádegas' etc.

Para 'perna' e 'pé' há apenas uma palavra — tinhame, que pode ainda significar 'mão'. Também se confundem 'cabelo' e 'pêlo' em 
orangê. As perífrases, neste campo, baseiam-se nas funções naturais: a boca é 'buraco de comida' jequê de cureio; o seio é 'buraco de leite' jequê de mavera ou 'coisa de guardar leite' imbondo de caxá mavera. Para as partes sexuais não faltam palavras: o órgão sexual feminino se representa apenas por cuxipa, mas o masculino, através de metáforas análogas às do português, pode ser imbuete ('pau'), imbuta ('cobra', 'lingüiça'), camargo ('saco') ou ainda, quando doente, erpido. Por outro lado, é a partir de cuxipa que se formam quase todas as perífrases verbais significando o ato sexual: tipurá a cuxipa (lit. 'possuir a boceta'), caxá cuxipa (lit. 'dar boceta'), rastá cuxipa (lit. 'arrastar boceta'), baté um cuxipa (lit. 'bater uma boceta'), cavacá o cuxipa (lit. 'cavacar a boceta') e mexê no cuxipa (lit. 'mexer na boceta'). Para 'ânus' há os vocábulos janô e inca e a perífrase jequê de caxá conema (lit. 'buraco de fazer fezes').

No campo "Trabalho", apareceram apenas dois nomes de profissão: viriango 'soldado' e ocaia de cuxipa 'prostituta' (lit. 'mulher de boceta'). Registrou-se, no entanto, a oposição empregador X empregado, em cavinguero 'patrão' e cuete do curimba 'trabalhador' (lit. 'homem do trabalho'). A palavra para 'trabalho', curimba, também significa 'terra', como já foi dito aqui. As ferramentas se designam todas pelo termo genérico moco, que também pode significar 'arma'.

Não ocorreu nas entrevistas uma só palavra relativa à mineração, seja no campo "Trabalho", seja em "Minerais". ${ }^{3}$ O fato parece estranho, já que Bom Despacho se liga historicamente a uma vila do ouro, Pitangui, e tem hoje a extração de cristais de rocha como uma de suas atividades econômicas.

O campo definido como "Números, pesos, medidas, moedas e cores" é extremamente pobre. Não há numerais nem unidades de peso ou de medida, mas apenas vocábulos de significação genérica relativos a quantidade, como avura 'grande', 'muito' e catita 'pequeno', 'pouco'.

Também não há distinções de moedas, mas apenas o dinheiro ingura ou missongue. Enfim, parece-nos especialmente significativo que as cores no vocabulário "africano" da Língua do Negro da Costa se restrinjam a apenas duas: cafuvira 'preto' e oli 'branco'. ${ }^{14}$ Para

\footnotetext{
${ }^{13}$ Não consideramos entre os minerais o vocábulo mongo 'sal', por ocorrer sempre relacionado à alimentação.

${ }^{14}$ Sabe-se que o número de cores e a fronteira entre elas sofre grande variação entre as línguas, e que, quando as cores se reduzem a apenas duas, elas são exatamente o preto e o branco.
} 
'branco' há ainda as perífrases tipara de mavera (lit. 'cara de leite') e cor do omenha (lit. 'cor da água').

No campo das "Qualidades e defeitos", há poucos vocábulos "africanos". Registramos: abife 'feio', opepa 'bonito', moná 'novo', ocora 'velho', tibanga 'bobo', 'triste', uarrufo 'forte', 'bravo', e insu 'azedo'. Mas as qualidades podem ser representadas todas pelo adjetivo avura, e os defeitos, por catito.

Essa observação nos conduz a uma das características mais marcantes do léxico da Língua do Negro da Costa: a extrema redução dos itens, que se compensa pela extensão do significado.

Em seu conhecido estudo dialetológico, Amadeu Amaral observa que o vocabulário do dialeto caipira é bastante restrito, de acordo com "as exíguas necessidades de expressão dos que o falam". ${ }^{15}$ O que dizer, então, do vocabulário da Língua do Negro da Costa, uma língua usada exclusivamente em situações especiais? Em outros termos, se já é reduzido o número de palavras utilizadas pelos habitantes da Tabatinga e da Cruz do Monte nas suas comunicações cotidianas, em família, no trabalho e entre amigos, quando usam o português regional, muito mais reduzido é, certamente, o vocabulário que utilizam essencialmente nas "conversas de botequim", quando o instrumento de comunicação é a Língua do Negro da Costa. Para que se tenha uma idéia mais exata da limitação do léxico da Língua do Negro da Costa, basta saber que os vocábulos "africanos", que constituem sua quase totalidade, no nosso levantamento, somam apenas 176.

Por outro lado, observamos que a Língua do Negro da Costa lança mão de alguns recursos que funcionam como uma espécie de compensação da sua extrema pobreza lexical. Em primeiro lugar, verifica-se o que poderíamos chamar de polissemia generalizada: as palavras adquirem novos significados a todo momento, de acordo com as necessidades de expressão do falante, e é preciso que o interlocutor se mantenha sempre atento aos contextos situacional e verbal para que se estabeleça a comunicação.

Isso se dá com tal freqüência que em alguns casos é impossível definir o rol de significados normalmente atribuídos a determinadas palavras. Como ocorre em português popular, com os nomes coisa, negócio, troço, trem, e os verbos coisar e transar, a Língua do Negro da Costa também apresenta os seus vocábulos passe-partout.

\footnotetext{
${ }^{15}$ AMARAL. O dialeto caipira, p. 55.
} 
É o caso, por exemplo, do verbo caxá, que se presta às mais diversas significações, definidas pelo contexto, verbal e situacional. Em uma frase como Ficô muita cuete sem caxá ingura, o significado 'receber' só se realiza através do objeto direto ingura 'dinheiro' e das afirmativas que cercam a frase: trata-se de uma conversa sobre a destruição, pela chuva, da lavoura de feijão onde a informante trabalhava, fato que teria deixado o patrão sem dinheiro. Daí, ficô muita cuete sem caxá ingura 'ficô muita mulhé sem recebê'. Assim, o verbo caxá se presta à constituição de inúmeras perífrases com significações que se definem sempre pelo nome que o segue: caxá conema 'defecar' (lit. 'fazer fezes'), caxá no isquife 'copular' (lit. 'fazer na cama'), caxá cuxipa 'copular' (lit. 'dar boceta'), caxá o moco 'matar' (lit. 'disparar a arma').

O mesmo ocorre com o substantivo imbondo, cujos significados só se definem através do contexto, não apresentando, pelo menos aparentemente, nenhuma relação entre si. Em uma história de casamento, contada durante uma entrevista, imbondo ocorreu com o sentido de 'aliança': A ocaia foi tipurá o cassucaro no granjão (...), o camonim tipurô os imbondo ('A mulhé foi casá no padre (...), o menino levô as aliança'). Em outra gravação, o falante usou a mesma palavra para se referir à barrigueira que tecia por encomenda: $O$ cuete vem atrais do imbondo dele e num tá pronto, né? ('O cara vem atrais da barrigueira dele e num tá pronta, né?').

Essa expansão do significado vocabular se dá, como é normal, a partir de associações semânticas, mais precisamente através da metáfora e da metonímia, que possibilitam a constituição de palavras de significação genérica. À falta, por exemplo, de um vocábulo para significar 'urina', o falante da Língua do Negro da Costa recorre, por metáfora, à palavra disponível na língua para 'água' — omenha. Essa mesma palavra é usada também para 'sangue', 'chuva', enfim, para 'qualquer líquido'. O processo metonímico possibilita, por exemplo, o uso do mesmo vocábulo - tinhame - para nomear os membros contíguos 'perna' e 'pé'.

A perífrase é outro recurso de que se vale constantemente o falante para expressar significados não representados no léxico da Língua do Negro da Costa. Na constituição dessas perífrases entram predominantemente vocábulos nocionais "africanos", como em caxá cuxipa 'copular' (lit. 'dar boceta'), conjolo dos viriango 'cadeia' (lit. 'casa dos soldados'), conjolo de matuaba 'bar' (lit. 'casa de cachaça'), mingüé do sengue 'onça' (lit. 'gato do mato'), ocaia meu tata 'mãe' (lit. 'mulher meu genitor'). 
Mas há também, em menor escala, perífrases em que se juntam vocábulos nocionais "africanos" e portugueses, como em cor do omenha 'branco' (lit. 'cor da água'), batê no isquife 'dormir' (lit. 'bater na cama') ou conjolo dos pé junto 'cemitério' (lit. 'casa dos pés juntos').

A metáfora, a metonímia e a generalização de sentido, processos semânticos que mencionamos há pouco, são muito importantes na formação das perífrases. É a metáfora que permite ao falante, à falta de uma palavra para 'lua', por exemplo, recorrer ao vocábulo cumba 'sol' e construir a perífrase cumba do oteque (lit. 'sol da noite'). É a metonímia que está na base da perífrase urunanga de gombê (lit. 'roupa de boi'), usada para 'tambor'. ${ }^{16} \mathrm{~A}$ palavra conjolo, a partir da generalização de seu significado, de 'casa' para 'lugar', prestou-se, no nosso corpus, à formação de nada menos que 25 perífrases, de que já citamos alguns exemplos nos parágrafos anteriores.

É importante salientar aqui o caráter instável desse tipo de construção. "Conceito vocabular apresentado por meio de uma expressão sintática", na definição de Mattoso Câmara, ${ }^{17}$ a perífrase não possui a estabilidade dos compostos e está sempre sujeita às variações do estilo, ou seja, das escolhas individuais. Assim, para um mesmo significado, 'lua', por exemplo, encontramos as perífrases cumba do oteque (lit. 'sol da noite'), cumba do bambi (lit. 'sol do frio') e cumba da hora do bambi (lit. 'sol da hora do frio'). Essa instabilidade formal, no nosso entender, se insere no contexto geral de extrema variabilidade que caracteriza a Língua do Negro da Costa, como língua exclusivamente oral que é. Por outro lado, pode constituir-se em mais uma estratégia a serviço da ocultação do conteúdo das conversas, na medida em que o falante tem sempre a possibilidade de construir a cada momento uma nova perífrase, com base em novas associações de idéias.

Em contraste com a extrema instabilidade formal e semântica observada no plano da língua, notamos, no plano do discurso, uma forte insistência em alguns temas. "É bom quando é turma assim, né? Fala bobage, a gente alembra. (...) Tem que falá é bobage.”

\footnotetext{
${ }^{16}$ Evidentemente, o significado metonímico 'tambor' pressupõe um significado intermediário 'couro', que, entretanto, não foi documentado.

${ }^{17}$ CÂMARA JÚNIOR. Dicionário de lingüística e gramática, p.191.
} 
Assim se refere Sueli, ${ }^{18}$ moradora da Cruz do Monte, ao que parece ser o tema predileto dos falantes da Língua do Negro da Costa: a "bobage", isto é, o sexo. Reforçando a importância do vocabulário relativo ao corpo humano, em especial aos órgãos e atos sexuais, a insistência na temática sexual é, acreditamos, uma das manifestações do clima de confronto que caracteriza os contextos de uso da Língua do Negro da Costa. Porque, sendo o sexo um tabu para a nossa sociedade, conversar sobre ele constitui uma violação das leis sociais e, portanto, uma agressão aos brancos, que são, afinal, os defensores dessas leis. ${ }^{19}$

Entretanto, na medida em que essa agressão se realiza numa língua inacessível aos agredidos, ficam impunes os agressores, como está claro na fala de Vandiquim, marido de Sueli:

Não, ma sabe o que que é, Sueli? É porque nóis tano aí com essa turminha ninguém qué que os otro pegue, né?, o que a gente tá conversano na mesa. Então nóis conversamo, conversamo, conversamo... e num sai nada, num conversa nada a num sê na gíria.

Em outras palavras, o caráter de código secreto da Língua do Negro da Costa, com que, aliás se casa muito bem a denominação de "gíria", garante a seus falantes total impunidade. Esse processo vem a ser para eles uma fonte de prazer, o que se evidencia nos risos que, nas entrevistas, acompanham sempre as conversas de ordem sexual.

Mas nem só de sexo e risos se nutre a Língua do Negro da Costa. Ressaltam nas entrevistas pelo menos mais dois temas importantes pela ênfase que recebem e, conseqüentemente, por revelarem muito do universo cultural dos falantes: a sobrevivência e a repressão. $O$ primeiro deles aparece, como é de se esperar, entrelaçado a três subtemas: a alimentação, o trabalho e o dinheiro. É o que se percebe, por exemplo, no seguinte trecho de entrevista, em que um rapaz da Cruz do Monte conversa com uma amiga da Tabatinga sobre a possibilidade de ter filhos:

\footnotetext{
${ }^{18}$ Sueli é filha de Bacará, apontado nas entrevistas como um dos mais antigos falantes da LNC, já referido à página 69.

${ }^{19}$ Em uma das entrevistas gravadas em bar, a entrevistadora foi objeto desse tipo de "agressão sexual". Os entrevistados se puseram, em determinado momento, a fazer sobre ela comentários de ordem sexual que poderiam ter dificultado o prosseguimento da entrevista, não fosse o fato de eles ignorarem que àquela altura ela já entendia a LNC.
} 
- Pois é, aí os camonim chega no conjolo do cuete, né?: - É, ocora, eu quero mavera, eu quero mavera, eu quero mavera... Comé que eu vô tipurá? A ingura catita.

- Curimba, uai.

- Ab, curimba!... Eu tô curimbano já avura, né? Num dá. Curimbá mais que eu curimbo num tem jeito, né, Parecida?

- É... Pára de caxá matuaba, uai.

- Uai, só se eu fizé os camonim pitá conjema, se eu fizê os camonim pitá conjema aí dá pra mim curiá mais, ocaia.

(— Pois é, aí os menino chega em casa, né?: - É, pai, eu quero leite, eu quero leite, eu quero leite... Comé que eu vô arrumá? O dinheiro poco.

- Trabalha, uai.

— Ah, Trabalha!... Eu tô trabalhano já demais, né? Num dá. Trabalhá mais que eu trabalho num tem jeito, né, Parecida?

— É... Pára de bebê pinga, uai.

— Uai, só se eu fizé os menino morrê, se eu fizé os menino morrê aí dá pra mim comê mais, mulhé.)

Entre os numerosos exemplos da ênfase no tema da sobrevivência, destacamos este trecho de entrevista em que Fiotinha, em conversa com seu irmão Zé Baiano, conta sobre o patrão que deixou de pagar aos trabalhadores:

$\bar{E}$, até a ingura dele onte ficô meia memo reduzida, porque ficô muita cuete sem caxá ingura. É, por isso que eu tô veno esses moná, cuete, cafuvira, ocora, ocaia cassucara é... percisano fazê cureio, num tem jeito de curiá, porque num caxa ingura. Pois é, amanhã num caxa no orumo. Amanhã ninguém injira no conjolo do curima não.

(É, até o dinhero dele onte ficô meio memo reduzido, porque ficô muita gente sem recebê. É, por isso que eu tô veno esses menino, home, preto, velho, mulhé casada é... percisano fazê comida, num tem jeito de comê, porque num tem dinhero. Pois é, amanhã num vai no caminhão. Amanhã ninguém vai no trabalho não.)

Quanto ao outro tema enfatizado nas entrevistas, a repressão, liga-se, invariavelmente, como é comum entre nós, a dois elementos: 
a violência e o policial. Veja-se, como exemplo, o trecho abaixo, em que os mesmos Fiotinha e Zé Baiano comentam uma briga num bar de Tabatinga:

- O otro machucô o cafuvira.

- Tava caxano matuaba.

- Pois é, viriango tá caxano.

- Tirô a omém, tirô sangue no cuete assim.

(...)

- Será que eles vão achá o cuete que caxô o imbuete?

- Ab, já tá no sengo uma hora dessas. Ele tá no sengo, Fiota, já foi pro sengo. No sengo muito tempo...

- Os viriango vai fazê igual fez com aquele cuete esses dia.

- Ali mete o muque em cima e vai: - Injira não, que o muque de undara caxa, mais caxa pra pitá conjema! O tinhame tá só jogano curima pra trais.

(...)

- O viriango achô ele?

- Achô lá conjolo do cuete ocora.

- E aî? Levô ele pro conjolo do viriango?

- Levô. Ficô treis dia no conjolo de viriango, e caxano imbuete nele.

(- O otro machucô o preto.

- Tava bebeno pinga.

— Pois é, o soldado tá prendeno.

— Tirô sangue, tirô sangue no cara assim.

(...)

— Será que eles vão achá o cara que desceu o pau?

— Ah, já tá no mato uma hora dessas. Ele já tá no mato, Fiota, já foi pro mato. No mato muito tempo... 
— Os soldado vai fazê igual fez com aquele cara esses dia.

— Ali mete o revolve em cima e vai: - Corre não, que o revolve atira, mais atira pra matá! A perna tá só jogano terra pra trais.

$$
\text { (...) }
$$

— O soldado achô ele?

- Achô lá na casa do pai.

- E aî? Levô ele pra cadeia?

— Levô. Ficô treis dia na cadeia, e desceno o pau nele.)

Contra as armas da polícia, a gente da Tabatinga e da Cruz do Monte parece mesmo só poder contar com a agilidade das próprias pernas. O recurso é, pois, jogá curima pra trais, 'correr', 'fugir'. Daí, certamente, a perífrase usada na Língua do Negro da Costa para 'camburão': injira que o cuete avura envém, decalque da frase portuguesa tão popular entre os nossos marginais: Corre, que lá vem os bome. ${ }^{20}$

Resumindo, diríamos que a insistência em certos temas nas conversas (sexo, sobrevivência e repressão) e a concentração de vocábulos em determinados campos semânticos (corpo, natureza, alimentos), bem como a redução extrema em outros campos (vestuário, lazer, parentesco, profissões, religião), são reflexos, no nível do discurso e do léxico, da realidade sócio-cultural dos falantes da Língua do Negro da Costa.

${ }^{20}$ A utilização de estrutura frasal na constituição de perífrases ou mesmo compostos de valor nominal não é de todo desconhecida do português. Veja-se, por exemplo, maria-vai-com-asoutras, de valor substantivo, ou unidos venceremos, de valor adjetivo. 


\section{LINGUA DO NEGRO DA COSTA UMA LINGUAA RTIUAL.}

Essa linguage é feia é por isso, que tem gente que num compreende ela. Às vez eu canto aqui ó: Deus Maria, Deus Maria, Nazaré, São José... a muié vizinha acha que eu tô falano mau dela. (...) Essa linguage é bonita demais... ma é pra quem sabe, né? Jesus Pinto

Se, como nos afirma Jesus Pinto, para os não-iniciados a Língua do Negro da Costa é uma "língua feia", já que não a compreendem, para seus falantes a beleza da língua reside exatamente nisso. Em outras palavras, é sobretudo como meio de ocultação de conversas que eles a usam e com isso freqüentemente se divertem quando vão aos bares do centro da cidade. Para situações de comunicação, entre si e com os de fora, a língua utilizada é o português, que todos dominam, em sua modalidade dialetal regional.

Já na fala de Jesus se percebe claramente que a utilização da língua se dá, em geral, em situações de confronto com não-falantes. A mulher vizinha, que, ao ouvi-lo cantar a música religiosa, se julga objeto de maledicência, personifica todos os não-falantes da Língua do Negro da Costa, os habitantes do centro da cidade, os ricos, os brancos, enfim, todos os não integrantes da comunidade a que pertence Jesus: "Essas palavra... diz que é bonita, eu acho feio esse trem, feio demais. Sabe por quê? Qu'eu num gosto de falá da vida aieia."

Essa comunidade, constituída de habitantes da periferia, pobres e negros, tem, evidentemente, muito o que falar dos moradores do centro da cidade. Afinal, trata-se dos patrões, dos detentores do poder conferido pelo capital, herdeiros daqueles que, num passado não tão remoto, tiveram como escravos os antepassados da gente da Tabatinga e da Cruz do Monte.

Em outras palavras, a Língua do Negro da Costa, em sua função de código secreto, coloca em pauta conflitos sociais que remontam ao 
período da escravidão e encontram continuidade hoje, no sistema de produção capitalista, que reserva aos descendentes dos antigos escravos o lugar não tão diverso de operários, subempregados ou desempregados. De fato, segundo depoimentos de falantes sobre as origens da Língua do Negro da Costa, já no passado ela era utilizada para ocultar aos senhores a fala dos negros escravos, quando planejavam uma fuga ou trocavam informações sobre, por exemplo, onde encontrar alimento. Veja-se, a propósito, este trecho das anotações feitas por Cristina Pinheiro e Ângela Linhares sobre a Língua do Negro da Costa, em 1977:

\begin{abstract}
Vocês sabem, né? vocês que já estudaram sobre isto sabem que eles passavam muita fome! E com essa língua eles podiam falar com os outros, mesmo frente aos patrões, sobre lugares onde podiam encontrar comida. Tinha rapadura ou queijo na casa sobrando? Tipura timberéia de orongômi! ${ }^{1}$
\end{abstract}

Isso nos traz alguma luz sobre o problema da classificação sociolingüística da Língua do Negro da Costa. Uma questão fundamental que se coloca aos estudos das línguas africanas no Brasil é saber se aqui se teriam formado crioulos do tipo dos que existem na costa africana e nas ilhas de Cabo Verde, São Tomé e Príncipe. Ora, os crioulos situam-se entre as línguas mistas surgidas a partir da necessidade de comunicação entre indivíduos de línguas diferentes postos em contato através de relações comerciais. Em sua formação, está prevista uma fase de pidgin, em que esta língua só é usada na situação que motivou seu aparecimento. Com o passar do tempo e, evidentemente, dependendo das relações sociais entre os dois grupos lingüísticos, esse pidgin pode expandir seu uso para outras situações de vida dos falantes, chegando a ser utilizado em toda e qualquer circunstância e tornando-se língua materna de um dos grupos. A esse estágio da língua é que se chama crioulo.

No que diz respeito à função e às situações de fala, portanto, a Língua do Negro da Costa nada tem de crioulo, já que não se destina essencialmente à comunicação e, ao que tudo indica, jamais chegou a ser língua materna. Aliás, a transmissão da Língua do Negro da Costa não se dá de pai para filho, mas entre amigos, numa faixa etária entre 11 e 20 anos, ou seja, quando o indivíduo já domina totalmente a

${ }^{1}$ ANOTAÇÕES feitas para um trabalho da disciplina de Sociologia do Curso de Comunicação Social da FAFICH/UFMG, 1977. 
língua materna e começa a intensificar as relações fora da família. É sobretudo nessas situações de lazer que ela é utilizada, diferentemente também dos pidgins, que surgem das relações de trabalho.

Do ponto de vista formal, os estudiosos dos contatos lingüísticos observaram que tanto os pidgins quanto os crioulos são constituídos de léxico europeu e gramática predominantemente nativa, exatamente o oposto do que se verifica na Língua do Negro da Costa, cujos elementos africanos estão no léxico, enquanto a gramática é portuguesa. Por outro lado, a Língua do Negro da Costa, enquanto língua de uso restrito a determinadas circunstâncias, apresenta uma série de características comuns aos pidgins, quais sejam: vocabulário extremamente reduzido, polissemia generalizada, freqüente recurso à perífrase, redução das flexões e extrema variação fonética.

Em síntese, vê-se que, se do ponto de vista funcional a Língua do Negro da Costa se encontra radicalmente distanciada do que seria um pidgin ou um crioulo, sob o aspecto formal ela em muito se aproxima deles. Isso nos sugere a hipótese de que ela venha a ser o resultado da evolução de um pidgin ou crioulo que teria existido efetivamente no período da escravidão.

A possibilidade de ter havido crioulos no Brasil é tema da dissertação de mestrado do prof. Félix de Carvalho, ${ }^{2}$ que, depois de discorrer sobre o processo de fixação da língua portuguesa no Brasil e expor as teorias sobre os crioulos, conclui pela inexistência desses falares no País. Admite, no entanto, a existência de pidgins durante a colonização. Segundo sua tese, esses pidgins não teriam evoluído para crioulos, porque "a nenhuma das três raças interessou preservar as modalidades lingüísticas resultantes dos primeiros contatos". Ao contrário, afirma, "índios e negros, sobretudo os últimos, inclinaram-se em direção à cultura européia, assimilando os padrões de comportamento e a língua do colonizador". ${ }^{3}$ Isso se explicaria pelo fato de que "o ideal do negro era aproximar-se do branco, identificar-se com ele, assimilar seus padrões de cultura, especialmente sua língua e sua religião. Achavam eles que assim teriam mais possibilidade de ascenderem na escala social. As negras nunca colocaram obstáculo no seu cruzamento com o branco. Sabiam que seus descendentes teriam melhor destino na mesma proporção em que sua pele fosse

\footnotetext{
${ }^{2}$ CARVAlHO. Falares crioulos do Brasil.

${ }^{3}$ Ibidem. p.72.
} 
tornando-se mais clara". $\mathrm{O}$ autor aponta ainda dois fatores que teriam impedido a formação de crioulos no Brasil: a uniformização das culturas de origem dos africanos, resultante da sua condição de escravos, que os teria enfraquecido culturalmente, e, ainda, o seu contato íntimo com os brancos, no trabalho doméstico, que teria facilitado o aprendizado do português. 5

Com relação à existência de pidgins no Brasil, Félix de Carvalho não está só. Para Arthur Ramos, ${ }^{6}$ houve duas "línguas gerais" de origem africana no Brasil: uma de base banto - mais especificamente quimbundo - e outra de base nagô — língua do grupo sudanês. Também Olabiyi Babalola Yai refere-se a esta última como "língua veicular" da comunidade negra da Bahia. ${ }^{7}$ Aryon Dall'Igna Rodrigues entende que "uma outra se tornou língua franca entre membros de comunidades lingüisticamente heterogêneas", ${ }^{8}$ até cair em desuso. Para Rosa V. M. Silva, formaram-se vários pidgins em diversos pontos do País. ${ }^{?}$

Yeda Pessoa de Castro também afirma a constituição, no Brasil colônia, de "falares de emergência" nascidos da necessidade de comunicação entre africanos de procedência diversa, num primeiro momento, e entre africanos e portugueses, num segundo momento. Forma-se, então, inicialmente, o que ela chamou "dialeto das senzalas" - mistura de diferentes línguas africanas em que pode ter havido predomínio da língua de maior prestígio social, que, de acordo com as cifras do tráfego, seria do grupo banto. A intensificação do contato entre negros e brancos, verificada sobretudo a partir do período mineratório, quando o negro é utilizado também no trabalho doméstico, teria gerado novas misturas: o "dialeto das minas", nas vilas de mineração, e o "dialeto rural", nas fazendas de gado.

Diferentemente de Félix de Carvalho, Yeda Pessoa de Castro acredita terem sido as semelhanças lingüisticas entre o português e algumas línguas africanas o principal fator a favorecer, com o tempo,

${ }^{4}$ CARVAlHO. Falares crioulos do Brasil, p.35.

${ }^{5}$ Idem.

${ }^{6}$ RAMOS. A aculturação negra, p.136-153.

7 YAI. Cultura, p.94-100.

${ }^{8}$ RODRIGUES. Levantamento e documentação da realidade lingüística do nordeste urbano e rural.

${ }^{9}$ SILVA. Universitas, p.33-95. 
o nivelamento desses pidgins afro-portugueses, que resulta, em última instância, no seu desaparecimento como línguas de comunicação. O desenvolvimento urbano que se segue à criação das vilas de mineração e a divulgação progressiva da educação formal são, ainda segundo Yeda de Castro, fatores externos que aceleram a imposição do português como língua de dominação econômica.

A partir de determinado momento, é, pois, da língua portuguesa que negros e brancos se utilizam nas comunicações inter- e intragrupais. Fenômenos como a Língua do Negro da Costa nos fazem supor que, por outro lado, alguns grupos de negros, certamente mais arraigados às suas tradições, teriam conservado o pidgin, ao lado de outras manifestações culturais que se mantêm até hoje entre nós (embora evidentemente alteradas pelo contato com os brancos ou índios), de que são exemplos, em Bom Despacho, a cestaria, no âmbito do artesanato, e as danças do Congado, no âmbito do folclore. O cultivo dessas tradições deve estar ligado a elites negras, a que se referem, com certeza, expressões que aparecem em declarações colhidas na Tabatinga sobre a Língua do Negro da Costa: "Língua usada pelos negros tradicionais antigos do bairro Tabatinga", "gíria tradicional do povo da Tabatinga", "língua do tempo do cativeiro, falada pelos antigos" ou "inventada pelo pessoal mais antigo do bairro". A conservação do pidgin por essas elites culturais é determinada, ao que nos parece, por uma consciência negra desenvolvida por certos elementos de cor concentrados num mesmo espaço geográfico, como forma de resistência à dominação branca a que foi submetida, grosso modo, a totalidade dos pretos no Brasil.

Admitamos a formação de um pidgin na região de Bom Despacho. Desse pidgin à Língua do Negro da Costa teria havido uma série de transformações no que diz respeito à função reservada à língua nas relações sociais e, paralelamente, em aspectos de sua estrutura formal. Assim é que, servindo a princípio de meio de comunicação entre negros escravos, o pidgin se constitui unicamente de formas tomadas a línguas africanas: ao ser utilizado, entretanto, também pelos senhores, em seus contatos com os escravos, ele passa a incorporar vocábulos e construções da língua portuguesa. O uso crescente desta língua por parte dos africanos e seus descendentes determina uma evolução do pidgin no sentido de um distanciamento progressivo de suas origens africanas, a ponto de se transformar num português com léxico africanizado e flexões reduzidas ao mínimo indispensável para os fins 
da comunicação. Esse português relexificado e desflexionado seria a Língua do Negro da Costa.

Na medida, porém, em que os negros passam a dominar o português e a utilizá-lo em todas as situações de comunicação, os pidgins afroportugueses vão perdendo sua razão de ser enquanto instrumentos da comunicação diária. Entretanto, pelo menos em núcleos de resistência cultural negra, essa perda não determina sua morte, mas uma mudança radical no seu papel social: eles passam, então, a servir para ocultar aos brancos conteúdos intercambiados pelos negros, a princípio provavelmente com propósitos práticos, como a troca de informações sobre onde encontrar comida ou sobre planos de fuga, já referidos aqui, e posteriormente com objetivos mais sutis.

No processo evolutivo do convívio lingüístico no Brasil, certamente houve períodos de extrema complexidade, como já observou Maurizio Gnerre:

A história social parece apontar para uma contraposição entre grupos de escravos de diferentes nações e entre esses e os escravos crioulos, e, ainda, entre os escravos em geral e os negros livres. Esta característica de ausência de um pólo comum de definição de uma identidade única, por exemplo, de 'escravo' pode estar na base da diferenciação lingüística e do abandono dos falares não-portugueses. ${ }^{10}$

Para Gnerre, teriam existido, então, comunidades lingüisticas complexas, caracterizadas pela variabilidade ou por um continuum lingüístico constituído por:

1) falantes nativos de algumas línguas africanas (ewe, bantu), que podiam usar também a variedade regional do português, ou, talvez, alguma variedade lingüística mista; 2) 'crioulos', isto é, negros nascidos no Brasil, que não eram falantes nativos de nenhuma língua africana, mas que podiam falar e compreender alguma língua, ou 'meia língua', e falavam o português regional; 3) 'crioulos' que das línguas africanas só conheciam textos, ditados, frases soltas e léxico, sem chegar a dominar produtivamente nenhuma língua a não ser o português regional. ${ }^{11}$

Conhecidos e utilizados também pelos senhores, os pidgins afroportugueses, para cumprir seu novo papel de código secreto, terão que sofrer alterações formais no sentido de perderem a transparência

\footnotetext{
${ }^{10}$ GNERRE. O corpus dos vissungos de São João da Chapada, p.8.

${ }^{11}$ Idem.
} 
para os brancos. O recurso constante, ou até mesmo abusivo, à analogia e à perífrase serão os meios encontrados na própria estrutura do pidgin para resolver essa questão. O desinteresse dos brancos por esses falares, que já não lhes são úteis, desde que se tornou possível a comunicação com os negros em português, teria contribuído para a sua evolução no sentido de se tornarem línguas de ocultação.

Com a queda do regime de escravidão e as conseqüentes mudanças nas relações sociais entre brancos e negros, o valor prático desses pidgins é gradativamente substituído por um valor simbólico. Eles passam então a ser utilizados para marcar diferenças entre brancos e negros, atribuindo a esses últimos uma identidade enquanto grupo étnico-cultural.

Mais do que o conteúdo veiculado entre os negros passa a interessar o fato de que os brancos não têm acesso a ele. No confronto que aí se estabelece, o negro se coloca, portanto, não mais como o grupo totalmente despojado de seus valores, mas como senhor de uma cultura diversa da do branco e inacessível a ele. O vocabulário africano garante aos negros, através da impermeabilidade da língua, o status de estrangeiros, que os distingue positivamente, compensando a situação de marginalidade em que sempre viveram, a princípio como escravos e hoje como subempregados ou desempregados.

Essa interpretação que adotamos aqui foi proposta por Peter Fry e colaboradores, em seus estudos sobre o mesmo fenômeno na comunidade de Cafundó, no estado de São Paulo: "Tudo se passa como se, por uma espécie de mecanismo compensatório, fosse criado um espaço mítico no interior da situação de degradação econômica e social, característica da história das populações negras no Brasil, espaço no qual seria possível uma como que renovação ritual de uma certa identidade perdida. (...) Reconhecendo as origens africanas da 'língua', os brancos da vizinhança que tendem a ver a gente do Cafundó como 'vagabundos' são também obrigados a atribuir-lhes uma certa importância enquanto falantes dessa estranha linguagem." ${ }^{12}$

A Língua do Negro da Costa, como a do Cafundó, seria, pois, o resultado da evolução de um pidgin em dois sentidos: por um lado, temos um "aportuguesamento gramatical", que já tomou completamente a fonologia, a morfologia e a sintaxe; por outro lado, temos uma "africanização lexical". Essas alterações formais teriam acompanhado

${ }^{12}$ FRY, VOGT, GNERRE. Mafambura e caxapura: na encruzilhada da identidade, p.119. 
mudanças funcionais que transformaram um meio de comunicação em um código secreto, tendo como objetivo atualizar, para seus falantes, um passado remoto, uma África mítica em que os indivíduos negros eram livres, donos de seu espaço de terra, do trabalho, do seu destino, afinal.

Otto Jespersen faz referência a casos semelhantes, como a língua usada pelos todas, na Índia meridional, quando diante de bagadás ou de tâmis, para que só sejam compreendidos por seus companheiros. No seu entender, essas "línguas artificiais de ocultação podem surgir sempre que um grupo, pequeno ou grande, de pessoas tenha interesse em falar de modo que as demais não compreendam o que dizem. Há todo tipo de razões para esse segredo, e a extensão em que se desenvolve esse processo de ocultação pode variar consideravelmente. Uma palavra ou sinal mutuamente convencionado pode dar origem a uma linguagem secreta". ${ }^{13}$

Sobre as formas dessas línguas, Jespersen observa que as mais comuns são aquelas usadas nas brincadeiras infantis, em que se intercalam na palavra determinadas sílabas. "As formas mais difíceis dessas línguas de ocultação", continua, "são produzidas quando, em lugar de se modificarem as palavras correntes lançando mão de um único recurso, se inventam palavras novas ou tomam-se de empréstimo vocábulos de línguas que os vizinhos desconhecem". ${ }^{14}$

Neste último caso se enquadraria a Língua do Negro da Costa, certamente. Entretanto, chamá-la "língua de ocultação" parece-nos enfatizar excessivamente seu caráter de código secreto, colocando-a ao lado de ocorrências de outro grau de complexidade, como as línguas usadas em jogos infantis, a exemplo da "língua do pê", tão comum entre as crianças brasileiras.

A Língua do Negro da Costa se aproxima muito mais do que Vendryes chamou "língua especial": "uma língua que só é empregada por grupos de indivíduos que se encontram em circunstâncias especiais". ${ }^{15}$ Entre as línguas especiais, inclui os jargões técnicos, as línguas litúrgicas e as gírias, em sentido restrito e em sentido lato.

\footnotetext{
${ }^{13}$ JESPERSEN. Humanidad, nación, indivíduo desde el punto de vista lingüístico, p.249. (A tradução das citações desta obra é de minha responsabilidade).

${ }^{14}$ Ibidem. p.244-247.

15 VENDRYES. Le langage, p.293. (A tradução das citações desta obra é de minha responsabilidade).
} 
Algumas dessas línguas especiais são línguas diferentes da língua ordinária. Assim o latim utilizado por muito tempo pelos cientistas em suas relações internacionais. Eles escolheram como língua especial para se comunicar com outros estudiosos uma língua morta; nossos padres fazem o mesmo para se dirigir a Deus. O sânscrito, uma outra língua morta, continua sendo, na Índia, a língua dos pânditas, ou seja, dos letrados. ${ }^{16}$

Vendryes explica o uso de uma língua especial entre cientistas pela necessidade de comunicação das idéias em países de línguas diversas. Quanto ao uso litúrgico de uma língua diferente daquela do dia-a-dia, entende que reflete a obediência à tradição e, acima de tudo, a necessidade de distinguir o sagrado do profano.

A Língua do Negro da Costa estaria aí, entre as línguas especiais. Partilha com a gíria o fato de funcionar como sinal diacrítico que marca o grupo de negros da Tabatinga por oposição aos brancos do centro da cidade. Aliás, por alguns de seus falantes, ela é também chamada de gíria da Tabatinga, gíria dos cativeiro ou simplesmente gíria. Com as línguas litúrgicas, a Língua do Negro da Costa divide a função ritual, que atualiza para esses negros a sua identidade africana, através da tradição lingüística.

Segundo Vendryes, as línguas especiais se definem não só por se distinguirem da língua corrente, mas também por servirem "de comunicação mais ou menos secreta a um número restrito de indivíduos". ${ }^{17}$ Não é outra coisa que, na sua linguagem, nos dizem Jesus e Zé Baiano a propósito da Língua do Negro da Costa:

Porque se eu dizê assim um cureio, a senhora num entende o que que é cureio, entende? A senhora num sabe. O cureio qué dizê eu quero amuçá com meus companhero. Vai a senhora num entende. Se eu pedi um copo d'água eu falo: omen, omenha. A senhora num entende. Se eu dizê assim o camberelo, a senhora num entende, entende? Carne.

(Jesus Pinto)

Cê compreendeu cumé que é, né? Se ocê falá que é pa fazê, aí cê já tá contano que é pa fazê. Aí não, é pa caxá pa injira po cureio. Aí nego fica indeciso. Fala: Ah, injira de que jeito? Num entendi essa não.

(Zé Baiano)

${ }^{16}$ VENDRYES. Le langage, p.294.

17 Ibidem. p.293-294. 
Ainda segundo Vendryes, as línguas especiais têm em comum o fato "de serem especiais com relação a uma mesma língua; e quando se examina a sua formação, verifica-se que elas procedem de uma mesma tendência, que consiste em adaptar a língua às funções do grupo que a emprega". ${ }^{18}$ Assim, os jargões profissionais ligam-se ao trabalho, bem como até certa medida as gírias, que se relacionam também a outras "artes", entre as quais se incluem o roubo e a mendicância, ao passo que as línguas litúrgicas ligam-se a cultos religiosos. Acrescentaríamos, ainda, lançando mão da terminologia de Peter Fry e colaboradores, as "línguas rituais", ${ }^{19}$ relacionadas a ritos profanos.

Fenômenos como a Língua do Negro da Costa e o Cafundó são, enfim, evidências de que "as mudanças de estrutura social se traduzem por mudanças de estrutura lingüística”, como já observava Meillet em $1906 .{ }^{20}$ E de que essa correlação se verifica não só nas sociedades de castas, como se acreditou durante algum tempo, mas também nas sociedades de classes.

${ }^{18}$ VENDRYES. Le langage, p.294.

${ }^{19} \mathrm{Cf}$., por exemplo, FRY, VOGT, GNERRE. Mafambura e caxapura: na encruzilhada da identidade.

${ }^{20}$ Citado por CUVILLIER. Sociologia da linguagem e da escrita, p.197. 


\section{AS PALAVRAS SECRETAS}

Essas palavra... diz que é bonita. Eu acho feio esse trem, feio demais. Sabe por quê? Qu'eu num gosto de falá da vida aieia.

Jesus Pinto

Este capítulo reúne, em ordem alfabética, as palavras "africanas" da Língua do Negro da Costa, ou seja, aquelas assim consideradas pelos falantes. Com o objetivo de orientar a consulta, daremos aqui alguns esclarecimentos quanto às informações contidas nos verbetes, sua disposição e sua apresentação gráfica.

Procurando respeitar a grande variabilidade que caracteriza a Língua do Negro da Costa, como língua essencialmente ágrafa que é, registramos sempre, em cada verbete, em letras maiúsculas, todas as variantes encontradas para o vocábulo que o encabeça. As variações que interpretamos como tendo sido formadas por processos ou morfemas diferentes, como cuetim, cuetitim, cuetitico, constituíram novos verbetes. $\mathrm{Na}$ tentativa de tornar mais fluente a leitura deste vocabulário, transcrevemos as variantes das palavras, primeiramente, segundo a norma ortográfica em vigor para o português. Alguns vocábulos, que só ocorreram fora de contexto, isto é, nas entrevistas de disponibilidade vocabular, ou em frases muito truncadas, ficaram sem qualquer anotação referente ao gênero, pois o caráter variável dessa categoria na Língua do Negro da Costa torna impossível a sua identificação.

Com relação ao significado das palavras, registramos todos aqueles que ocorreram nas entrevistas. Receberam tratamento diverso os verbos caxá, injirá e tipurá, que se comportam como vocábulos passe-partout, isto é, adquirem os significados mais diversos, de acordo com o contexto, verbal e situacional. No caso desses verbos, listamos alguns de seus inúmeros sentidos, aqueles que nos pareceram nortear as mudanças semânticas de cada um, e fornecemos exemplos de sua ocorrência em frases completas que permitissem ao leitor observar pelo menos o contexto verbal. 
Sempre que possível, fornecemos abonação para cada significado diferente de um mesmo vocábulo. As abonações foram todas tiradas de nossas gravações e vêm grafadas em itálico, seguidas de tradução para o português. Os significados que só ocorreram nas entrevistas de disponibilidade vocabular ou em frases muito truncadas ficaram sem abonação.

Na tradução das abonações, procuramos nos aproximar ao máximo da modalidade do português usada normalmente pelos falantes da Língua do Negro da Costa. Aliás, nos próprios enunciados da Língua do Negro da Costa ocorrem, como ficou evidenciado no Capítulo V, elementos do português regional. Conservados nas traduções, esses elementos, gramaticais e lexicais, foram os primeiros indicadores da modalidade do português que deveríamos usar, para dar ao leitor a idéia exata da Língua do Negro da Costa, no que ela tem de regional, popular e exclusivamente oral.

Em seguida às abonações, registramos as palavras africanas ou afro-portuguesas encontradas na bibliografia a que tivemos acesso, sempre que vimos nelas uma semelhança formal e semântica com a palavra objeto do verbete. Anotamos o último sobrenome do autor, a data da publicação da obra e a página onde se encontra o vocábulo em questão. As referências bibliográficas completas encontram-se no final deste livro. Em lugar da ordem alfabética por autor, seguimos para esse registro a ordem cronológica das publicações.

Finalmente, após o registro bibliográfico de palavras africanas ou afro-portuguesas relacionadas com o verbete, listamos, em letras maiúsculas, perífrases formadas com o vocábulo que o encabeça. Para isso, adotamos o critério do Diccionario da Real Academia Espanhola, também seguido por Aurélio Buarque de Holanda Ferreira no seu Novo Dicionário da Língua Portuguesa. De acordo com esse critério, a entrada da perífrase se faz por seu primeiro substantivo, seguindo-se, na ordem de preferência, o verbo, o adjetivo, o pronome e o advérbio. Não se levam em conta os verbos auxiliares e os de ligação, a não ser que sejam parte essencial, imutável, da construção. Acrescentamos, para o nosso caso, a preferência pelos vocábulos de provável origem africana sobre os portugueses. Dessa forma, caxá omenha $(\mathrm{V}+\mathrm{S})$ e omenha avura $(\mathrm{S}+\mathrm{Adj}$.$) entram ambas em$ omenha, único substantivo da expressão; já conjolo de caxá omenha $(\mathrm{S}+$ Prep. $+\mathrm{V}+\mathrm{S})$ entra em conjolo, primeiro substantivo; e buraco de cureio $(\mathrm{S}+$ Prep. $+\mathrm{S})$ entra em cureio, primeiro substantivo "africano" da perífrase. 


\section{ABREVIATURAS E SÍMBOLOS}
Adj. ...... adjetivo
$A d v$....... advérbio
f. ........... feminino
lit. ........ literalmente
m.......... masculino
or ......... origem
p.......... página
pl. ......... plural
pop...... popular
S. .......... substantivo
sing....... singular
$v$. .......... verbo

[p] como no português pala ['palə] - LNC ['põgu] 'chapéu'

[b] como no português bala ['balə] - LNC [bã'bi] 'frio'

[t] como no português todo ['todu] - LNC ['tatə] 'genitor'

[d] como no português dano ['dãnu] - LNC [ũ'darə] 'fogo'

[k] como no português cara ['karə] - LNC [kõ'zolu] 'casa'

[g] como no português gado ['gadu] - LNC [gõ'be] 'boi'

[f] como no português fato ['fatu] - LNC ['fut $\int \mathrm{I}$ ' 'céu'

[v] como no português vida ['vidə] - LNC [vi'ru] 'defunto'

[s] como no português seta ['setə] - LNC ['sẽgI] 'mato'

[z] como no português zebra ['zebrə] - LNC [vi'zũgə] 'baile'

[S] como no português chave ['Savi] - LNC [Sapi'Sapi] 'comida'

[3] como no português jato [3atu] - LNC [3ã'no] 'ânus'

[m] como no português mar ['max] - LNC [matu'abə] 'cachaça'

[n] como no português nada ['nadə] - LNC [mõ'na] 'criança'

[n] como no português manhã [mã'nã] - LNC [kafã'naki] 'dente'

[1] como no português lado ['ladu] - LNC [lipo're] 'laranja'

[r] como no português cara ['karə] - LNC [a'vurə] 'grande' 


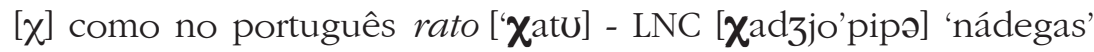

[i] como no português pita ['pitə] - LNC ['wiki] 'açúcar'

[i] como no português tinta ['t $\mathrm{f} \tilde{\mathbf{i}}$ tə] - LNC [oru'f $\tilde{\mathbf{1}}$ ] 'peixe'

[e] como no português cabelo [ka'belu] - LNC ['kwet II] 'homem'

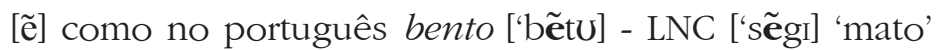

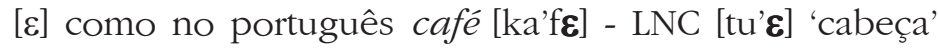

[a] como no português $p a ́$ ['pa] - LNC [mõ'na] 'novo'

[ã] como no português planta ['plãtə] - LNC [t]i'bãgə] 'bobo'

[ə] como no português bola ['bələ] - LNC [ĩ'g ərə] 'cavalo'

[o] como no português bolo ['bolv] - LNC [kõ'zolu] 'casa'

[õ] como no português ponta ['põtə] - LNC [i'bõdu] 'coisa'

[u] como no português pura ['purə] - LNC [wa' $\chi \mathbf{u f u}]$ 'forte'

[ũ] como no português fungo ['fũugu] - LNC ['pũgI] 'milho'

[j] como no português pai ['paj] - LNC [o'kajə] 'mulher'

[w] como no português lingüiça [lĩ' gwisə] - LNC ['wiki] 'açúcar'

[t $\int$ ] como no português mineiro tia ['t $\mathbf{f}$ iə] - LNC [a't $\mathbf{f j a p u}$ ] 'pouco'

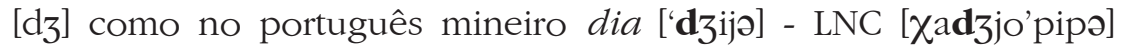
'nádegas'

[I] como no português noite ['nojt $\left.\int \mathbf{I}\right]$ - LNC ['kwet $\mathbf{I}$ ] 'homem'

[u] como no português bolo ['bolu] - LNC [i'bõdu] 'coisa'

[ə] como no português sala ['salə] - LNC ['kũbə] 'sol' 
ABIFE [a'bifi], ABIFO [a'bifu]. Adj. Feio.

AIAQUE [aj'akI], AIATO [aj'atu]. S.m. Queijo. O aiaque num vai dá pa injirá não? O queijo num vai dá pa saí não?

AIAQUINZIM [ajakí'zĩ]. S.m. Queijinho.

ARUMUTE [arũ'mutfi], URUMUTE [urũ'mut]I]. S.f. Abóbora.

Dornas Fo, 1938, p.145. arimuta. Abóbora (or. quimbunda).

ASSANGUE [a'sãgi], ASSANGO [a'sãgu], ASSENGUE [a'sẽgi], IMASSANGO [ỉma'sãgu], MISSANGUE [mi'sãgi]. S.m. Arroz. Ah, nóis temo que curiá o assango memo com camberela, tipoquê, pó de bugue. Ah, nóis temo que comê o arroiz memo com carne, feijão, farinha de milho.

Dornas Fo, 1938 , p.147. massango. Arroz (or. quimbunda).

ATIAPO [a'tfjapu], TIAPO ['tfjapu]. Adj. 1. Pouco. Isso é ingura que tá meio atiapo. Isso é dinheiro que tá meio poco. 2. Pequeno. O cuete tá muito atiapo. O cara tá muito pequeno. 3. Estragado. E se caxá (imbera) fica pió, porque o tipoquê aí vai tudo atiapo. E se chovê fica pió, porque o feijão aí vai tudo estragado. 4. Rasgado.

Dornas Fo, 1938, p.149. tiapoá. (Gente) ruim (or. quimbunda).

AVURA [a'vurə]. Adj. 1. Grande. Eu vô caxá matuaba avura. Eu vô tomá uma pinga grande. 2. Grosso. O imbuete é avura. O pau é grosso. 3. Muito. Matuaba caxô avura. Bebeu muita pinga. 4. Que possui qualquer qualidade positiva: bonito, bom, rico etc. Tinhame da ocaia é avura. A perna da mulhé é bonita. Adj. 5. Muito. Eu tô curimbano já avura, né? Eu tô trabalhano já muito, né? 6. Depressa. Lá vai injirano avura. Lá vai ino depressa.

Cannecattim, 1859, p.6. iavúl, q'uiavúl (pl.) Adj. Muito(a) (bundo).

Ibidem. p.38. avúl. Adv. Muito (bundo).

Raimundo, 1933, p.57. kiavutu. Grande (banto).

Dornas Fo ${ }^{\circ}$ 1938, p.145. avuro. Muito(a) (or. quimbunda).

Vogt, Fry, Gnerre, 1980, p.29. vavúru. Bonito.

FrY, 1982, p.120. vavuru. Grande, gordo, aberto, alto, muito, mais.

Gnerre, Fry, Vogt, [s.d.], p.2. vavúru. Grande. 
AVURAÇO [avu'rasu]. Adj. Grandalhão. Cajuvira catito num dá não. Tem que sê avuraço, né? Cafezinho num dá não, tem que sê bem grande, né?

AVURINHA [avu'rĩnə]. Adj. Bonitinho.

$\mathrm{B}$

BABATIMÃO [babatfi'mãw̃]. S.m. Suã de vaca.

BAMBI [bã'bi]. S.m. Frio. Ab, isso (caxá tiploque) é bom na hora do bambi memo. Ah, isso (calçá sapato) é bom na hora do frio memo.

Machado Fo, 1964, p.71. bambi. Frio.

Ibidem. p.122. mbambe. Frio.

Dornas Fo, 1938, p.145. bambi. Frio (or. quimbunda).

Cannecattim, 1859, p.99. nbãmbi. Frio (bundo).

BANJERÊ [bãze're], CONJERÊ [kõze're]. S.m. comida. No conjolo de matuaba quais num caxa o banjerê, uai. No bar quais num tem comida, uai.

CAXÁ O BANJERÊ [ka'`a u bãze're]. Comer (lit. ingerir a comida).

BIGUIBOTE [bigi'botfI]. S.m. Macarrão.

C

CAFANHAQUE [kafã'naki], CAFANHACO [kafã'naku] GAFANHAQUE [gafã'naki]. S.m. 1. Dente. A ocaia num caxa cafanhaque no buraco de cureio. A mulhê num tem dente na boca. 2. Bigode.

CAFUVIRA [kafu'virə], CAVUVIRA [kavu'virə]. Adj. Preto. O oranjê da ocaia é cafuvira. O cabelo da mulhé é preto. S.m. ou $f$. E o cavuvira catito ali, ó. Ele é tibanga, o cavuvira catito ali? E o pretinho ali, ó. Ele é bobo, o pretinho ali?

CAJUVIRA [kazu'virə]. S.m. Café. Cê tipura o cajuvira? Cê toma café? Dornas Fo, 1938, p.149. tiuvira, kiuvira. Café (or. quimbunda).

CAMARGO [kã'maðgu]. S.m. 1. Saco. Pois (o teia) dentro do camargo e injirô po conjô. Pois (o tatu) dentro do saco e foi pra casa. 2. Pênis. Vô te falá. Caxá meu camargo naquele cuxipo ali, te falá procê, Deus 
me livre! Vô te falá, enfiá meu pinto naquela boceta ali, vô te falá, Deus me livre!

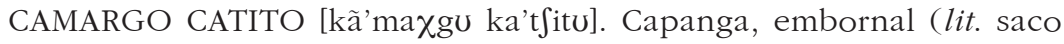
pequeno).

CAMBAJARA [kãba'zarə], CAMBAJARRA [kãba'zaðə]. S. Ônibus.

CAMBÉM [kã’bẽ̃]]. S.m. 1. Vasilha, recipiente. 2. Panela. Pois é, mas a camberela dá pra fazê no cambém. Pois é, mas a carne dá pra fazê na panela. 3. Copo. Seu cambém já injirô já? Seu copo já esvaziô?

CAMBÉM DE CAJUVIRA [kã'bẽj dzi kazu'virə]. Xícara (lit. vasilha de café). CAMBÉM DE CURIÃ O CAJUVIRA [kã’bẽj dzi kuri’ã u kazu'virə]. Xícara (lit. vasilha de beber o café).

CAMBÉM DE CUREIO [kã’bẽj dzi ku'reju]. Panela (lit. vasilha de comida). CAMBÉM DE CAXÁ O CUREIO [kã'bẽj dzi ka’`a u ku'reju]. Prato (lit. vasilha de colocar a comida).

CAMBÉM DE CURIMBA [kã’bẽj dzi ku'rỉbə]. Ferramenta (lit. instrumento de trabalho).

CAMBÉM DE OMENHA [kã’bẽ̃ dzi õ'mẽnə]. Copo (lit. vasilha de água). CAMBÉM DE CAXÁ OMENHA [kã’bẽ̃ dzi ka'Ja ơ’mẽnə]. Talha (lit. vasilha de colocar água).

CAMBÉM DE ORANJÊ [kã’bẽj dzi orã'ze]. Chapéu (lit. vasilha de cabelo). CAMBÉM DE CAXÁ MAVERA [kã’bẽj dzi ka’\}a ma'verə]. Lata de leite (lit. vasilha de colocar leite).

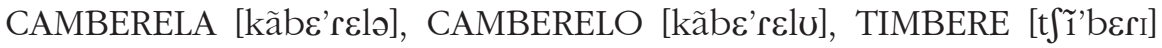
TIMBERÉIA [t $\mathrm{t}$ ĩbe'rejo]. S.m. ou $f$. 1. Carne. E se o cuete quisé uma camberela pra curiâ? E se o cara quisé uma carne pra comê? 2. Corpo. Camberela tudo no cumba. O corpo todo no sol.

Dornas Fo, 1938, p.146. camberéra. Carne (or. quimbunda).

CAMBERELA DE OMENHA [kãbe'rela dzi õ'mẽnə]. Carne de peixe (lit. carne de água).

CAMBERELA DE SENGUE [kãbe'relə dzi sẽgi]. Carne de caça (lit. carne de mato).

CAMBERELUDA [kãbere'ludə]. Adj. Carnuda, gorda, (mulher) boa; pop. boazuda. Ocê é tibanga, hein? Aquela ocaia cambereluda queria tipurá cena com cê e cê num quis, hein? Ocê é bobo, hein? Aquela boazuda queria transá com cê e cê num quis, hein?

CAMBÓIA [kã’bojə]. S. Locomotiva.

CAMBUÁ [kãbu'a]. S.m. Cachorro. Cambuá avura num dá pra mim não, uai. Cachorro grande num dá pra mim não, uai. 
Cannecattim, 1859, p.126. caimbua. Cão pequeno (bundo).

Ibidem. p.126. imbouá. Cão pequeno (conguês).

Ibidem. p.9. imbua. Cadela (bundo).

Ibidem. p.100. imbua. Cachorro (bundo).

LANG, 1906, p.103. ombwa. Cão (nhaneca).

Dornas Fo, 1938, p.147. m’boá. Cachorro (or. quimbunda).

Machado Fo, 1964, p.123. omboá. Cachorro.

CAMBUÁ DO SENGUE [kãbu'a du sẽgi]. Lobo, raposa (lit. cachorro do mato).

CAMONA [kã'mõnə], CAMONE [kã'mõni]. S.m. e $f$. Criança.

Cannecattim, 1859, p.4. camóna. O filho pequeno (bundo).

LANG, 1906, p.106. omona. Filho. Neto (nhaneca).

Dornas Fo, 1938 , p.146. camoná. Menino (or. quimbunda).

CAMONÃO [kãmõ'nãw̃]. S.m. Meninão.

CAMONIM [kãmũ'nĩ]. S.m. Criança. A ocaia tem um comonim. A mulher tem um neném.

CAMONINHO [kãmũ'nĩnu]. S.m. Criança. A os camoninho, dexa ês injirá, uai. Alá os menino, dexa ês i, uai.

CAMONIM INJIRÁ [kãmũ'nĩ ỉzi'ra]. Engravidar (lit. criança crescer).

CAXÁ UM CAMONIM JEQUÊ [ka'`a ũ kãmũ'nĩ ze'ke]. Engravidar (lit. carregar uma criança barriga).

TÁ COM CAMONIM JEQUÊ ['ta kõ kãmũ'nĩ ze'ke]. Estar grávida (lit. estar com criança barriga).

CANDOMBORA [kãdõ'borə], CANDOMBÓIA [kãdõ'bəjə], CANDAMBÓIA [kãdã’bəjə], CANAMBÓIA [kãnã’bəjə], CONDOMBÓIA [kõdõ'bojə]. S.f. Galinha. Que tal o sinhô caxá umas duas candombora lá? Que tal o sinhô pegá umas duas galinha lá?

Dornas Fo, 1938, p.146. camdombô. Galo (or. quimbunda).

CANDOMBORA CATITA [kãdõ'borə ka'tfitə]. Pinto (lit. galinha pequena). CANDOMBORA DO SENGUE [kãdõ’borə du 'sẽgi]. Passarinho (lit. galinha do mato).

CANDOMBORAZINHA [kãdõbora'zĩnı]. S.f. Frango.

CANGURA [kã'gurə], CANGURO [kã'guru]. S.m. Porco. É só que ela num me deu um pedacinho de camberela do canguro. É só que ela num me deu um pedacinho de carne de porco.

Cannecattim, 1859, p.8. ngúlu. Porco (bundo).

LANG, 1906, p.103. ongulu, otyinguly. Porco (nhaneca). 
Dornas Fon, 1938, p.146. canguro, cangulo. Porco, leitão (or. quimbunda).

Machado Fo, 1964, p.119-123. canguro, onguro. Porco.

CASSUCARÁ [kasuka'ra]. V. Casar. Ele vai cassucarậ? Ele vai casá?

CASSUCARA [kasu'karə], CASSUCARO [kasu'karu]. S.m. ou f. Casamento. DE CASSUCARA [dzi kasu'karə]. Casado (lit. de casamento). É cuete já de cassucara ô vai pegá cassucara? Já pegô cassucara? É homem casado ô vai casá? Já casô?

TIPURÁ O CASSUCARA [t]ipu'ra u kasu'karə]. Casar (lit. fazer o casamento). A ocaia foi tipurá o cassucara no granjão e o camonim (...) tipurô os imbondo dês de pô nos timbuá. A mulhé foi casá no padre e o menino (...) carregô as coisa dês de pô nos dedo.

PEGÁ CASSUCARA [pe'ga kasu'karə]. Casar (lit. pegar casamento).

CASSUCARADO [kasuka'radu], SUCARADO [suka'radu]. Adj. Casado. É cassucarado? É casado?

CATIOLÁ [kat jjo’la]. V. roubar.

CATITIM [katfi'tsĩ]. Adj. 1. Pequenininho. Cêtipura o mavero da ocaia, tá catitim. Alá o seio da mulhé, é pequenininho. 2. Novinho. Tem, ocaia tem, um punhado de ocaia avura, umas ocaia catitinha lá. Tem, mulhé tem, um punhado de mulhé bonita, umas moça novinha lá. 3. Sem dinheiro, pop. duro, liso. Eu tô catitim, num caxo ingura nenhum, cuete. Eu tô durinho, num tenho dinheiro nenhum, cara. CATITO [ka't $\mathrm{itu}$ ], ACATITO [aka'tSitu]. Adj. Pequeno. Ô ocaia, dá pra caxá uma matuaba catita? Ô mulhé, dá pra bebê uma pinga pequena? 2. Pouco. Cangura ultimamente tá catito. Porco ultimamente tá poco.

Dornas Fo, 1938 , p.146. catito. Pequeno (or. quimbunda).

Machado Fo, 1964, p.120. catita. Pequeno.

Ibidem. p.129. coxito. Pequeno (or. ambunda).

CATOVELANA [katuve'lãnə], COTOVELANA [kotove'lãnə]. S.f. Faca. O cuete cafuvira quis caxá a cotovelana no cuete avura. O cara preto quis enfiá a faca no cara rico.

CAVICONVE [kavi'kõvi], CAVICOME [kavi'kõmi], CAVICONGO [kavi'kõgu], CAVICONGUE [kavi'kõgI], CONVICONVE [kõvi'kõvi], CONFICONFE [kõfi'kõfi]. S.m. Pão. Ô Dim, cê num tá vendeno cavicongo, mais, né? Ô Dim, cê num tá vendeno pão mais, né? 
CAVINGUERÃO [kavĩge'rãw̃]. S.m. Grande Proprietário. Cumbara avura aqui, meu fio. Ih! isso aí tem... sengue, tem... cavingurâo! Da cidade grande, meu fio. Ih!, Isso aí tem... fazenda, tem... fazenderão!

CAVINGUERO [kavĩ'geru], CAVINGUERA [kavĩ'gerə], CAVUNGUERO [kavũ'geru], CAVUNGUERA [kavũ'gerə], CAFUNGUERA [kafũ'gerə], VINDERO [vĩ'deru]. S.m. 1. Patrão. O cuete seu cavinguero lá do sengue. O seu patrão lá da roça. Adj. 2. Rico. Cê tipura o cuete... o cuete é cavinguera? Cê conhece o cara... o cara é rico?

Dornas $\mathrm{F}^{\circ}$, 1938, p.150. vindêro, vinderi. Branco (or. quimbunda).

CAVU [ka'vu]. S.m. Paletó. O cuete cafuvira tá de cavu. O cara preto tá de paletó.

CAXÁ [ka’aa], ACAXÁ [aka'`a]. V. Fazer, produzir, criar, entregar, mandar, jogar, atirar, receber, ganhar, pegar, carregar, trazer, guardar, pôr, ter etc. Funciona como um verbo passe-partout cujo sentido se define pelo contexto, verbal e situacional. Ficô muita cuete sem caxá ingura. Ficô muita mulhé sem recebê. Que tal o sinhô caxá umas duas candombora lá? Que tal o sinhô pegá umas duas galinha lá? Se o viriango caxá nego aqui... Se o soldado prendê nego aqui... Caxá matuaba, cuete? Tomá pinga, cara? Ô cuete, caxá o mungo na matuaba, cuete! Ô cara, põe sal na cerveja, cara!

Dornas Fo, 1938 , p.146. cachía. Chegar, estar (or. quimbunda).

CONEMA [kõ'nẽmə]. S.f. 1. Fezes. 2. Diarréia. Aí, no jeguê de cureio é assim, ó: ruma uma conema que num pára no curima nem no sengue. Aí, na barriga é assim, ó: ruma uma caganera que num pára no trabalho nem no mato.

Cannecattim, 1859, p.126. cunéma. Defecar (bundo).

Ibidem. p.126. néma. Defecar (conguês).

Castro, 1978, p.9. kunema. Defecar.

Ibidem. p.9. fazer nema. Defecar.

CAXÁ CONEMA [ka’’a kõ’nẽmə]. Defecar (lit. fazer fezes).

CONJEMA [kõ'zẽmə]. S.m. 1. Morte. 2. Cemitério. Fitô viru, foi pro conjema. Morreu, foi pro cemitério. 3. Terra.

Machado Fo, 1964, p.120. congembo. Morrer.

FrY, 1982, p.124. cuendá para o conjenga carunga. Morrer.

FITÁ CONJEMA [fi'ta kõ'zẽmə]. Morrer (lit. fitar mortẽ).

INJIRÁ PO CONJEMA [ïzi'ra pu kõ'zẽmə]. Morrer (lit. ir para o cemitério). 


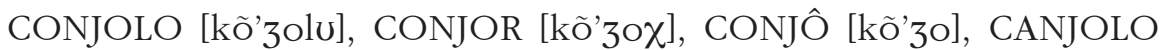
[kã'zolu]. S.m. 1. Casa. Mora longe daqui, no sengue. Então caxô conjolo no sengue. Mora longe daqui, na roça. Então fez casa na roça. 2. Gaiola.

Raimundo, 1933, p.56. onjoango, onjo-ia-ohango. Habitação, casa de conversa, sala (banto).

Dornas Fơ 1938 , p.147. injó, undió. Habitação, casa (or. quimbunda). Machado $\mathrm{F}^{o}$, 1964, p.123. onjó. Habitação, casa, rancho, cafua.

Vogt, Gnerre, 1978, p.13. injó. Habitação.

CONJOLO DE CAMBERELA [kổzolu dzi kãbe'relb]. Açougue (lit. casa de carne). CONJOLO DE CONJEMA [kỡzolu dzi kõzẽmə]. Cemitério (lit. casa de morte). CONJOLO DOS FITÁ CONJEMA [kõzzolu duz fi'ta kõ’zẽmə]. Cemitério (lit. casa dos fitar morte).

CONJOLO DE COVERA [kởzolu dzi ko'verə]. Hospital (lit. casa de doença). CONJOLO DOS CUETE OCORA [kõ'zolu dus 'kwet $\int \mathrm{r}$ o'korə]. Asilo (lit. casa dos homens velhos).

CONJOLO DE CURIMBA [kõ'zolu dzi ku'ribə]. Local de trabalho (lit. casa de trabalho).

CONJOLO DOS GOMBÊ [kõ’zolu duz gõ’be]. Curral (lit. casa dos bois). CONJOLO DE GRANJÃO [kởzolu dzi grã’zãw]. Igreja (lit. casa de Deus). CONJOLO DE GROZOPE [kởzolu dzi gro'zopi]. Bar (lit. casa de cerveja). CONJOLO DAS INGURA [kõ’zolu daz ĩ'gurə]. Banco (lit. casa dos dinheiros). CONJOLO DE INGURA AVURA [kơ’zolu dzi î'gurə a'vurə]. Banco (lit. casa de dinheiro muito).

CONJOLO DE MATUABA [kõ̃zolu dzi matu'abə]. Bar (lit. casa de cachaça). CONJOLO DAS OCAIA [kô’zolu daz o'kaja]. Bordel (lit. casa das mulheres). CONJOLO DE OCAIA DO CUXIPO [kơ’zolu dzi o'kaja du ku'sipu]. Bordel (lit. casa de mulher da boceta).

CONJOLO DE OMENHA [kởzolu dzi õ'mẽnə]. Sanitário (lit. casa de água). CONJOLO DE CAXÁ OMENHA [kõ’zolu dzi ka'Ja õ'mẽnə]. Sanitário (lit. casa de verter água).

CONJOLO DE FAZÊ OMENHA [kơ’zolu dzi fa'ze õ'mẽnə]. Sanitário (lit. casa de fazer água).

CONJOLO DE ORUM [kốzolu dzi o'rũ] Posto de gasolina (lit. casa de carro). CONJOLO DO TIPEQÜERA ETERNO [kởzolu du t $t$ ip $\left.\varepsilon^{\prime} k w \varepsilon r ə ~ \varepsilon^{\prime} t \varepsilon \chi n u\right]$. Cemitério (lit. casa da cama eterna).

CONJOLO DO UNDARA [kõ’zolu du ũ'dare]. Usina siderúrgica (lit. casa do fogo). CONJOLO DE URUNANGA [kõ’zolu dzi urũ'nãgə]. Loja de roupas (lit. casa de roupa).

CONJOLO DOS VIRIANGO [kõzolu duz viri'ãgu]. Cadeia (lit. casa dos soldados).

CONJOLO DO LONGADO [kởzolu du lõ'gadu]. Clube, casa de dança (lit. casa do rebolado). 


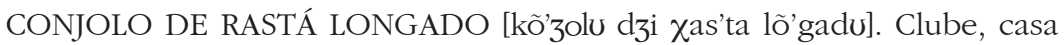
de dança ( lit. casa de arrastar rebolado).

CONJOLO DOS PÉ JUNTO [kõ'zolu dus 'pe 'zũtu]. Cemitério (lit. casa dos pés juntos).

CONJOLOZIM [kõzolu'zî]. S.m. Casinha. Nois injira prum conjolozim acatita no sengue, né? Nóis vai pruma casinha pequena na roça, né?

COREÃ [kore'ã]. S.m. Chapéu. O que que fica por baxo do coreã? Ah, o oranjé, tué. O que que fica por baxo do chapéu? Ah, o cabelo, a cabeça.

COVERA [ko'verə], CORVERA [kox'verə]. S.f. Doença. O meu (erpido) num tem covera não. O meu (pênis) num tem doença não.

LANG, 1906, p.106. ouvera. Doença (nhaneca).

DORnAs Fo , 1938, p.146. cuvéra. Dor (or. quimbunda).

MaCHADO $\mathrm{F}^{\mathrm{o}}$, 1964, p.120. caxicovera. Doença, moléstia.

CAXÁ COVERA [ka’’a kə’verə]. Adoecer (lit. pegar doença).

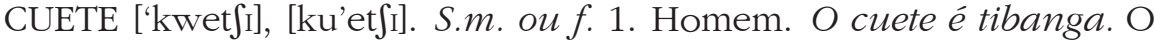
cara é bobo. 2. Pai. 3. Mulher. O cuete injirô pro otro cumbara, dexô a cuete, os camonim da cuete ficô tudo catito, sem urunanga, sem cureio. O cara mudô pra otra cidade, dexô a mulhé, os menino da mulhé ficô tudo pequeno, sem ropa, sem comida. 4. Gente. É, até a ingura dele onte ficô meia memo reduzida, porque ficô muita cuete sem caxá ingura.

Raimundo, 1933, p.56. ukueto. Meu ou nosso companheiro (banto).

Dornas Fo, 1938, p.148. ocuêto. Homem (or. quimbunda).

Machado $\mathrm{F}^{\mathrm{o}}$, 1964, p.125. ucuêto, vacuêto, acuêto. Companheiro. CUETE AVURA ['kwet I a'vurə]. Patrão, homem rico (lit. homem grande).

CUETE OCORA ['kwet II o'korə]. Pai (lit. homem velho).

CUETE DE CONJOLO DE GRANJÃO ['kwet I d zi kõ'zolu dzi grã'zãw̃]. Padre (lit. homem de casa de Deus).

CUETE DE CURIMBA ['kwet I d zi ku'ribə]. Trabalhador (lit. homem de trabalho).

CUETE DA OCAIA ['kwet I da o'kajə]. Marido (lit. homem da mulher).

CUETE DO MEU CONJOLO ['kwet $\mathrm{I}$ du 'mew kõ'zolu]. Pai (lit. homem da minha casa).

CUETE MEU TATA ['kwet I 'mew 'tatə]. Pai (lit. homem meu genitor). CUETE SEM CUETE ['kwet $\mathrm{I}$ 'sẽ j 'kwet $\mathrm{I}$ ]. Mulher solteira (lit. mulher sem homem).

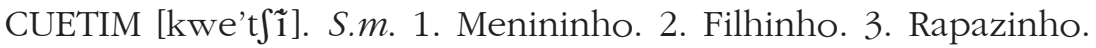

CUETITICO [kwetfi'tsiku]. S.m. 1. Menininho. 2. Filhinho. 3. Rapazinho. 


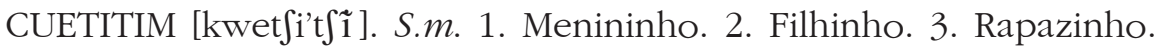

CUMBA ['kũbə], PUMBA ['pũbə]. S.m. Sol. Ele hoje caxô aqui rompê do cumba. Ele hoje passô aqui rompê do sol.

LANG, 1906, p.99. ekumbi. Sol (nhaneca).

Dornas Fo, 1938 , p.146. cumbe de uanja. Sol (or. quimbunda).

Idem. cumbe de otécame. Lua (lit. lume da noite) (or. quimbunda).

MACHADO Fo ${ }^{\circ}$ 1964, p.66-67. ucumbi. Sol (or. quimbunda).

CUMBA DO BAMBI ['kũbə du bã'bi]. Lua (lit. sol do frio).

CUMBA DA HORA DO BAMBI ['kũbə da 'orə du bã'bi]. Lua (lit. sol da hora do frio).

CUMBA DO OTEQUE ['kũbə du o'teki]. Lua (lit. sol da noite).

CUMBARA [kũ'barə], INCUMBARA [ĩkũ'barə]. S.m. ou $f$. Cidade. $O$ orumo é do cumbara avura. O carro é da cidade grande.

Dornas Fo, 1938, p.146. cumbara. Cidade, lugar habitado (or. quimbunda).

Machado Fo ${ }^{\circ}$ 1964, p.120. combaro. Cidade, lugar habitado.

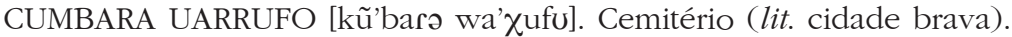

CUMBARA DE SÃO PEDRO [kũ'barə dzi ‘sã̃̃ 'pedru]. Cemitério (lit. cidade de São Pedro).

CUREIO [ku'reju], CUREIA [ku'rejə], CUREI [ku'rej]. S.m. Comida. Talvez que amanhã eu num vô no curimba não. Num tem ingura pa comprá curei... Talvez que amanhã eu num vô no trabalho não. Num tem dinheiro prá comprá comida...

CUREIO DE GOMBÊ [ku'reju dzi gõ'be]. Pasto (lit. comida de gado).

CAXÁ CUREIO [ka'`a ku'reju]. Comer (lit. ingerir comida).

JEQUÊ DE CUREIO [ze'ke dzi ku'reju] 1. Boca. 2. Barriga (lit. buraco de comida).

BURACO DE CUREIO [bu'raku dzi ku'reju]. Boca (lit. buraco de comida).

CURIÁ [kuri'a]. V. 1. Comer. Precisano fazê cureio, num tem jeito de curiá, porque num caxa ingura. Precisano fazê comida, num tem jeito de comê, porque num tem dinhero. 2. Copular. Esse cuete tava tipurano com uma ocora aí no conjolo da matuaba. Eu falei: cuete, num dá prá curiá. Ele falô assim: nós rasta pro sengue. Esse cara tava paquerano com uma mulhé velha aí no bar. Eu falei: cara, num dá pra comê. Ele falô assim: nós vai pro mato.

Cannecattim, 1859, p.12. curiá. Comer (bundo).

LANG, 1906, p.107. okurya. Comer (nhaneca).

Dornas Fon, 1938, p.146. curiá. Comer (or. quimbunda). 
CURIMBÁ [kurĩ'ba], CURIMÁ [kurĩ'ma]. V. Trabalhar. Óia, gente, eu preciso curimbá um poquinho, porque esse curimbo meu tem que entregá hoje. Óia, gente, eu preciso trabalhá um poquinho, porque esse trabalho meu tem que entregá hoje.

LANG, 1906, p.100. okulima. Cultivar a terra.

Ibidem. p.101. okuringa. Fazer, trabalhar (nhaneca)

Vogt, Gnerre, 1978, p.13. kurimá. Trabalhar.

Vogt, Fry, Gnerre, 1980. p.30. kurimá. Trabalhar.

FrY, 1982, p.128. curimando. Trabalhando.

CURIMBADÔ [kuriba'do]. Adj. Trabalhador. Os cuete imbanje da ocaia (...) é tudo curimbadô, curimba avura. Os cara irmão da mulhé (...) é tudo trabalhadô, trabalha muito.

CURIMBA [ku'ríbə], CURIMBO [ku'ríbu], CURIMA [ku'rimə], CURIMO [ku'rimu]. S.m. 1. Trabalho, ato de trabalhar. Padrim, ela é ruim de curimba. Nossa! Só sabe bebê aver. Padrim, ela é ruim de trabalho, só sabe bebê leite. 2. Local de trabalho. Então, a hora que nós chegô no curimo, né? as ocaia: Cadê a camberela? Cadê o conviconve? Então a hora que nós chegô no trabalho, né? as mulhé: Cadê a carne? Cadê o pão? 3. Produto do trabalho. (...) esse curimbo meu tem que entregá hoje. (...) esse trabalho meu tem que entregá hoje. 4. Terra. Pitô conjema, injirô pro cumbara uarrujo, cachô curima em cima. Morreu, foi pro cemitério, jogô terra em cima. 5. Pedra.

Dornas Fo, 1938, p.146. curimá. Trabalho (or. quimbunda).

Machado Fo, 1964, p.120. curima. Trabalho.

CAXÁ O CURIMBA [ka'ja u ku'rỉbə]. 1. Trabalhar (lit. realizar o trabalho). 2. Correr (lit. levantar a poeira).

CUXIPA [ku'Jipə], CUXIPO [ku'Jipu]. S.m. ou $f$. 1. Órgão sexual feminino, pop. boceta. O cuete mano diz que caxô o cuxipo dela já. Meu mano diz que já comeu a boceta dela. 2. Nádegas. Cuxipa avura, poxa! Bunda bonita, poxa!

Machado Fo, 1964, p.123. ochito. Carne.

Vogt, Fry, Gnerre, 1980. p.30. kusitá. Copular, urinar.

TIPURÁ A CUXIPA [t]ipu'ra a ku'Sipə]. Copular (lit. possuir a boceta).

CAXÁ CUXIPA [ka'`a ku'Sipə]. Copular (lit. dar a boceta).

RASTÁ CUXIPA [Xas'ta ku'Sipə]. Copular (lit. arrastar boceta).

BATÊ UM CUXIPA [ba'te ũ ku'Sipə]. Copular (lit. bater uma boceta).

CAVACÁ O CUXIPA [kava'ka u ku'Sipə]. Copular (lit. cavacar a boceta). MEXÊ NO CUXIPA [me'Je nu ku'Jipə]. Copular (lit. mexer na boceta). 
CUXIPADÔ [kuSipa'do]. Adj. Que pratica, com freqüência, o sexo ativo. As ocaia tipura só assim pra mim: é, cuete, cê é cuxipadô, né não, cuete? As mulhé fala só assim pra mim: é, cara, cê é comedô, né não, cara?

CUXIPÃO [kuSi'pãw̃]. S.m. Órgão sexual feminino grande, pop. bocetão. Ele cavacô o cuxipão dela, o camonim tá só injirano, todo amarrotado. Ele cavacô o bocetão dela, o menino tá só cresceno, todo amarrotado.

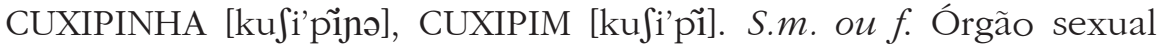
feminino pequeno, pop. bocetinha. Tipura o cuxipim dela, catitim, ó. Olha a bocetinha dela, pequenininha, ó.

$$
\text { E }
$$

ERPIDO [ex'pidu]. S.m. Pênis. Num demora vim com o erpido cheio de corvera, cuete. Num demora vim com o pinto cheio de doença, cara.

F

FUTE ['futfi]. S.m. 1. Espaço. 2. Céu. 3. Liberdade.

INJIRÁ NO FUTE [izi'ra nu 'futfi]. Voar ( $l i t$. andar no céu).

$\underline{G}$

GOMBÊ [gõ'be]. S.m. 1. boi. Ele caxa muito gombê. Ele tem muito boi. 2. Vaca. Mavero da ocaia tá pareceno até gombê do sengue. O seio da mulhé tá pareceno até vaca da roça. 3. Gado. Cheguei lá no conjolo do sengue, né?, caxá o gombê no conjolo dos gombê. Cheguei lá na casa da fazenda, né?, cuidá do gado no curral.

Cannecattim, 1859, p.8. ngombe. Boi (bundo).

Ibidem. p.168. ngúmbe. Vaca (conguês).

Idem. ngómbi. Vaca (bundo).

LANG, 1906, p.103. ongombe. Boi (nhaneca).

Dornas Fo, 1938 , p.148. orongombe. Boi (or. quimbunda).

Machado Fo , 1964, p.122-123. ngombe, ongombe. Boi.

Vogt, Gnerre, 1978, p.13. ngombe. Boi. 
Vogt et al. 1980, p.30. ngóbi. Boi, vaca, cavalo, burro.

FrY, 1982, p.120. ngombe. Boi.

GNerRe et al. [s.d.], p.2. ongómbi. Cavalo, jumento.

COSTELA DE GOMBÊ [kus'tzlə dzi gõ'be]. Banana (lit. costela de boi).

GOMBEZIM [gõbe'zĩ], GAMBENZIM [gãbẽ'z̃i]. S.m. Bezerro.

GOMBEZIM DO SENGUE [gõbe'z̃i du 'sẽgi]. 1. Veado. Se eu tivesse lá, um gombezim do sengue daqueles, eu is injirá até cambuá. Se eu tivesse lá, um veado daqueles, eu ia até caçá. 2. Homossexual. Cambuá num injira comigo não, (...) moco de undara tamém num anda, num carrego. Num caxo moco de undara pra caxá no gambezim do sengue. Cachorro num anda comigo não, (...) arma de fogo tamém num anda, num carrego. Num carrego arma de fogo pra atirá em bicha.

GRANJÃO [grã'zãw̃], GARANJÃO [garã'zãw]], GARANJAME [garã'zãmi]. S.m. 1. Deus. 2. Padre. A ocaia foi tipurã o cassucaro no granjão. A mulhé foi casá no padre.

Machado Fo, 1964, p.111. ganazambi. Deus.

COROA DE GRANJÃO [ko'roa dzi grã'zãw̃]. Abacaxi (lit. coroa de Deus). LEVÁ PRO GRANJÃO DE VIRU [le'va pru grã’3ãw̃ dzi vi'ru]. Matar (lit. levar para o Deus de defunto).

GROZOPE [gr’'zəpi]. S.m. Cerveja.

DE GROZOPE [dzi gro'zopi]. Bêbado (lit. de cerveja).

GROZOPIADO [grozopi'ado]. Adj. Bêbado. A ocaia achô que eu tava grozopiado. A mulhé achô que eu tava tonto.

GROZOPIM [grozo'pĩ]. S.m. Bebidinha. Num tem um grozopim pra nóis não, cuete? Devia tipurá um assim... um grozopim avura pra nóis, uai. Num tem uma bebidinha pra nóis não, cara? Devia arranjá uma assim... uma bebidinha boa assim pra nóis, uai.

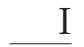

IMBANJE [1̃'bãzi], IMBANGUE [1̃'bãgI]. S.m. Irmão. Os cuete imbanje da ocaia tamém é tudo curimbadô, curimba avura. Os cara irmão da mulhé tamém é tudo trabalhadô, trabalha muito.

Cannecattim, 1859, p.99. panch'i (sing.), jipanch'i (pl.). Irmão(s) (bundo).

Ibidem. p.147. npángh. Irmão (conguês).

Machado $\mathrm{F}^{\mathrm{o}}$, 1964, p.122. manjangue. Irmão. 
IMBANJECO [ỉbã'zeku], IMBANJEQUE [ỉbã'zekI], BANJECO [bã'zeku]. S.m. 1. Qualquer instrumento musical: violão, sanfona, tambor etc. 2. Toca-disco. 3. Gravador. É, esse imbanjeco num vai dá pra tipurá não. É, esse gravadô num vai dá pra funcioná não.

IMBANJECO DE IMBUETE [ïbã'zeku dzi ĩbu'etfi]. Violão (lit. instrumento musical de madeira).

IMBERA [i'berə]. S.f. Chuva. Tomara que a imbera caxa uarrufo. Tomara que a chuva cai forte.

LANG, 1906, p.99. ombila. Chuva (nhaneca).

Dornas Fo, 1938, p.150. umbera. Chuva (or. quimbunda).

Machado Fo, 1964, p.123. ombera. Chuva.

TÁ DE IMBERA ['ta dzi î'berə]. Chover (lit. estar de chuva). Tá de imbera, num tem cumba não. Tá choveno, num tem sol não.

IMBIÁ [ỉbi'a]. S.m. Cigarro.

Dornas Fo, 1938, p.146. cambiá. Fumo (or. quimbunda).

IMBONDO [i'bõdu]. S.m. Qualquer objeto, coisa. O cuete vem atrais do imbondo dele e num tá pronto, né? O cara vem atrais do trem dele e num tá pronto, né?

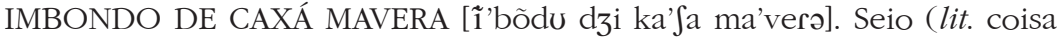
de guardar leite).

IMBUETÃO [íbwe'tãw]]. S.m. Pênis grande. Lá tem cada cuete avura, com imbuetão! Lá tem cada cara bonito, com pintão!

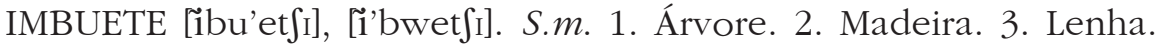
Aí, ó, orongome caxano imbuete. Aí, ó, cavalo carregano lenha. 4. Pau, vara. Cê caxa o imbuete nele, eu caxo o imbuete na ocaia. Cê mete o pau nele, eu meto o pau na mulhé. 5. Pênis. Eu caxo o imbuete avura na ocaia ocora. Eu meto o pinto duro na mulhé velha.

IMBUETIM [ibwe'tfĩ]. S.m. Pênis pequeno.

IMBUTA [i'butə], IMBUCA [i'bukə]. S. 1. Cobra. 2. Lingüiça. 3. Pênis. Dornas Fo, 1938, p.147. m'buta. Cobra (or. quimbunda).

INCA [ikə]. S.m. Ânus. Ele só sabe curiá inca de cuete. Ele só sabe comê cu de homem.

INCÃO [1'kãw̃]. S.m. Ânus grande. Cê precisa vê que cena, minha fia. Umas ocaia avura! Um incão! Um inca véio de guerra que cê precisa de vê. Cê precisa vê que cena, minha fia. Umas mulhé boa! Um cuzão! Um cu véio de guerra que cê precisa de vê. 
INDU [i'du]. S. Feijão.

INGANGA [i'gãgə]. S. Padre.

Dornas Fo , 1938, p.149. unganga. Sacerdote, padre, feiticeiro (or. quimbunda).

MACHADO Fo, 1964, p.122. nganga. Sacerdote, padre, feiticeiro.

INGORA [1'gərə]. S. Cavalgadura: mula, cavalo, jumento etc...

Dornas Fo, 1938 , p.148. n'goró. Cavalo (or. quimbunda).

Machado Fo, 1964, p.123. ongoró. Cavalo, égua.

INGURA [i'gurə]. S.f. Dinheiro. Depois te caxo ingura. Se a ingura num vié, a ocaia te caxa. Depois te dô o dinhero. Se o dinhero num vié, a mulhé te paga.

Dornas Fo, 1938, p.150. ungura. Dinheiro (or. quimbunda).

INGURAZINHA [igura'ziñə]. S.f. Dinheirinho. Ma lá no conjolo das ingura tem... caxa uma ingurazinha lá. Ma lá no banco tem... tem um dinherinho lá.

INJARA [i'zarə]. S.f. Pênis. Caxá injara na cuxipa du ocaio. Metê o pinto na boceta da mulhé.

INJARA MITOMO [i’zarə mitõmu]. Barriga (lit.?).

INJARÁ [ỉzi'ra] $V$. Ir, andar, correr, sair, crescer etc. Funciona como um verbo passe-partout cujo sentido se define pelo contexto, verbal e situacional. Injira que os cuete avura envêm. Corre que lá vêm os home. Vão injirá com a ocaia? Dá pa injirá com a ocaia? Num caxa corvera não? Vão saí com a mulhé? Dá pa transá com ela? Não pega doença não? Seu cambém já injirô já? Seu copo já esvaziô? Viu? por isso que o imbanjeco num qué injirá. Viu? por isso que o gravadô num qué funcioná. Dinha injira oruma muito bem, viu? Dinha dirige carro muito bem, viu?

INJIRA [1'zirə], INJIRO [i'ziru]. S.m. ou f. Caminho. É pegá o injira do curima memo, né? É curimá memo. É pega o caminho do trabalho memo, né? É trabalhá memo.

LANG, 1906, p.99. ondyila. Caminho (nhaneca).

Castro, 1978, p.13-14. injira. Caminho, rumo.

NA INJIRA DE TIPURA DE TINHAME [na Ĩ'zirə dzi tfi'purə dzi tfi’'nãmi]. A pé (lit. no caminho de ida de pé).

COISA DE INJIRA DE CUREIO ['kojzə dzi r'żirə dzi ku'reju]. Comida (lit. coisa de caminho de comida).

FAZÊ INJIRA [fa'ze 1̃'zirə]. Transportar (lit. fazer caminho). 
INQUIM [1'kî], INQUINHA [i'kỉnə]. S.m. Ânus pequeno. E um inquim avura ele tipura tamém? E um cuzinho bom, ele come também?

INSU [i’su]. Adj. Azedo.

ISQUIFE [is'kifi]. S.m. 1. Cama. Se eu vê que a imbera tá caxano, eu num injiro do isquife, ma num injiro memo. Se eu vê que a chuva tá caíno, eu num saio da cama, ma num saio memo.

CAXÁ NO ISQUIFE [ka’`a nu is'kifi]. Copular (lit. fazer na cama).

TIPURÁ NO ISQUIFE [t]ipu'ra nu is'kifi]. Cochilar (lit. encostar na cama).

BATÊ NO ISQUIFE [ba'te nu is'kifi]. Dormir (lit. bater na cama).

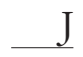

JANÔ [zã'no]. S.m. Ânus. Ele dexa a gente caxá o janô dele? Ele dexa a gente comê o cu dele?

CAXÁ O JANÔ [ka' Ja u zã’no]. Ter coito anal (lit. entregar ou possuir ânus).

JEQUÊ [ze'ke], INJEQUÊ [ize'ke], JIQUÊ [3i'ke], JIQUI [3i'ki]. S.m. 1. Buraco. Fomo caxá o teia no jiqui, no conjô dele. Fomo pegá o tatu no buraco, na casa dele. 2. Barriga. O jequê da ocaia tá avura. A barriga da mulhé tá grande. 3. Boca. Eu caxo undara nu injequê. Cê tamém caxa. Eu tenho oro na boca. Cê tamém tem.

Dornas Fo, 1938, p.147, indjequê. Capanga, sacola (or. quimbunda).

Machado Fo ${ }^{\circ}$ 1964, p.123, njequê. Capanga, sacola.

Vogt et al. 1980, p.30. ižeké. Bolsa.

GNERRE et al. [s.d.] ižeké. Bolsa.

JEQUÊ DE CUREIO [ze'ke dzi ku'reju]. 1. Boca. 2. Barriga (lit. buraco de comida).

JEQUÊ DE MAVERA [ze'ke dzi ma'verə]. Seio (lit. buraco de leite).

JEQUÊ DE CAXÁ CONEMA [ze'ke dzi ka'`a kõ'nẽmə]. Ânus (lit. buraco de fazer fezes).

JEQUÊ DE CURIÁ [ze’ke dzi kuri'a]. 1. Boca. 2. Barriga (lit. buraco de comer).

JEQUETIOTADA [3ekitjo'tadə]. Adj. Esburacada, furada. Ocaia que injira pro cumbara avura igual essa aí deve tê uma xuranha até jequetiotada, nê? Mulhé que vai pra cidade grande igual essa aí deve tê uma xuranha até furada, né? 
LONGADO [lõ'gadu]. S.m. Andar, gingado, rebolado. Tipura a ocaia. A o longado da ocaia. Olha a mulhé. Alá o rebolado da mulhé.

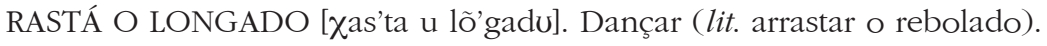

M

MASSARUNDÁ [masarũ'da]. S. Banana.

MARCANJÁ [maxkã'za]. V. Fumar. Não, essa matuaba eu num quero, que eu tô marcanjano. Não, essa pinga eu num quero, que eu tô fumano.

MARCANJIM [maxkã'zĩ]. S.m. Cigarrinho. Vô tipurá um marcanjim. Vô apreciá um cigarrinho.

MARCANZOJIM [maxkãzu'z̃i]. S.m. Cigarrinho.

MARCANJO [max'kãzu]. S.m. Cigarro. Ô camunim, vai lá no conjolo da matuaba lá e fala com o cuete pra mandá um marcanjo pro cuete aqui, depois o cuete caxa a ingura. Ô menino, vai lá no bar e fala com o cara pra mandá um cigarro pra mim, depois eu pago.

Cannecattim, 1859, p.166. macanha. Fumo (bundo).

Dornas Fo, 1938, p.147. macaia. Fumo (or. quimbunda).

MARUCO [ma'ruku]. S. Litro de cachaça.

MATAMBU [matã'bu], MATAMBÔ [matã'bo], MATAMBOA [matã'boa]. $S$. Mandioca. Eu num sô cangura pra gostá de matambu, uai. Eu num sô porco pra gostá de mandioca, uai.

Dornas Fo, 1938 , p.147. mutambo, mutambô. Mandioca (or. quimbunda).

Machado Fo, 1964 , p.122. matambô. Mandioca.

Vogt et al. 1980, p.30. mutôbo. Mandioca.

GNerre et al. [s.d.], p.30. mutôbo. Mandioca.

MATAMBU DOCE [matã'bu 'dosi]. Batata doce (lit. mandioca doce).

PÓ DE MATAMBU ['po dzi matã'bu]. Farinha de mandioca (lit. pó de mandioca).

MATUABA [matu'abə]. S.f. 1. Bebida alcoólica. 2. Cachaça. Ele caxô muita matuaba, né? Ele bebeu muita pinga, né?

MATUABA DE UÍQUE [matu'abə dzi 'wiki]. 1. Refrigerante. 2. Qualquer bebida sem álcool e doce (lit. bebida de açúcar). 
CAXÁ MATUABA NO TUÉ [ka’ Ja matu'abə nu tu'e]. Beber (bebida alcoólica) (lit. pôr bebida na cabeça). Ele caxô matuaba no tué demais, pô! Ele bebeu demais, pô!

MATUABAZINHA [matuaba'ziñn]. S.f. Cachacinha. Qué (um marcanjo) não? E uma matuabazinha? Num qué (um cigarro) não? E uma pinguinha?

MAVERA [ma'verə], MAVERO [ma'veru], MAVELO [ma'velu], MAVERDA [ma'vexdə], AVERA [a'verə], AVERO [a'veru], AVELO [a'velu], AVER [a'vex]. S.m. ou f. 1. Leite. Tem que trazê um aver, um aver de gombê, um trem assim... Tem que trazê leite, um leite de vaca, assim. 2. Seio. O cuete tá tipurano os timbuã na mavera da ocaia. O cara tá passano as mão no seio da mulhé.

Dornas Fo , 1938, p.147. mavêro. Leite (or. quimbunda).

MAVEROZIM [maveru'z̃i]. S.m. Leitinho. Um maverozim tamém, despistado. Um leitinho tamém, despistado.

MISSONGUE [mi'sõgI], MISSONGO [mi'sõgu]. S.m. Dinheiro.

MINGÜÉ [mĩ'gwe]. S.m. 1. Gato. 2. Onça.

MINGÜÉ DE CONJOLO [mĩ'gwe dzi kõ'zolv]. Gato (lit. gato de casa).

MINGÜÉ DO SENGUE [mĩ'gwe du 'sẽgI]. Onça (lit. gato do mato).

\section{MITOMO [mi’tõmu].? Ver INJARA MITOMO.}

MOCO ['moku], MOQUE ['moki], MUQUE ['muki], MUCO ['muku]. S.m. 1. Qualquer ferramenta ou instrumento de trabalho: enxada, enchadeco, foice etc. Ai fica ruim de curimá porque caxa omenha demais, aí num dá conta do muque, aí o cavinguero já chega, corre os tipara: é, injará com cuete pro conjô, porque num dá pra caxá ingura não. Aí fica ruim de trabalhá porque bebe água demais, aí num dá conta da ferramenta, aí o patrão já chega, corre os óio, é, mandá o cara pra casa, porque num dá pra pagá não. 2. Qualquer arma: revólver, espingarda, faca etc. O cuete rancó do muque, caxô o muque no tué dele. O cara rancó da arma, atirô na cabeça dele.

Dornas $\mathrm{F}^{\mathrm{o}}$, 1938, p.147. mocó. Faca (or. quimbunda).

MOCO CATITO ['moku ka'titu]. 1. Canivete. 2. Faca (lit. arma pequena). MOCO DE ARENA ['moku dzi a'renə]. Espingarda (lit. instrumento de arena). MOCO DE CURIÁ ['moku dzi kuri'a]. Prato (lit. instrumento de comer). MOCO DE CURIMBA ['moku dzi ku'ribə]. Ferramenta (lit. instrumento de trabalho).

MOCO DE UNDARA ['moku dzi ũ'darə]. Qualquer arma de fogo: espingarda, revólver etc. Eu injiro com o muque de undara tamém, uai. Eu ando com o revólver tamém, uai. 
CAXÁ O MOCO [ka’Ja u 'moku]. Matar (lit. disparar a arma). Pois a gaiola na porta do conjô dele (do teia), aí caxô o muque, pois dentro do camargo e injirô. Pois a gaiola na porta da casa dele (do tatu), aí matô e pois dentro do saco troxe pra casa.

MONÁ [mõ'na]. S.m. 1. Criança. Moná caxa o janô não. Menino num dá o cu não. 2. Filho. Adj. 3. Novo. O cuete é muito moná, né? O cara é muito novo, né?

Cannecattim, 1859, p.140. moná. Filho (bundo).

Ibidem, p.140. moána. Filho (conguês).

Raimundo, 1933, p.55. monamungua, muana-a-mungua. Filho de sal, afilhado, filho.

CAXÁ MONÁ [ka'Sa mõ’na]. Estar grávida (lit. carregar filho). Ocaia tá caxa moná. A mulhé tá grávida.

CAXÁ MONÁ NA INJARA MITOMO [ka'`a mõ'na na î'zarə mi'tõmu]. Estar grávida (lit. carregar filho na barriga).

MONGO ['mõgu], MUNGUE ['mũgi], MUNGO [mũgu]. S.m. Sal. Um menino pra batizá, o que que leva? (...) É mungue no tué. Um menino pra batizá, o que que leva? (...) É sal na cabeça.

LANG, 1906, p.107. omongwa. Sal (nhaneca).

Dornas Fo, 1938, p.147. mongo. Sal (or. quimbunda).

Machado Fo, 1964, p.123. omungá. Sal.

Raimundo, 1933, p.55. monamungua, muana-a-mungua. Filho de sal, afilhado, filho.

MONTECRISTO [mõt ${ }^{\prime}$ 'kristu]. S. Carvão. O cavinguero lá acaxa montecristo, acaxa gombê, acaxa oruma catito... O fazendero lá faz carvão, cria gado, tem carro...

MOXÉ [mo'se]. S. Sapo.

$\mathrm{O}$

OCAIA [o'kajə], OCAIO [o'kaju], CAIO ['kaju]. S.f. ou m. Mulher. Agora, essa ocaia, a ocaia cavuvira, que tem o mavero avura. Agora, essa mulhé, a mulhé preta, que tem o peito grande.

LANG, 1906, p.106. omukay. Mulher (nhaneca).

RaImundo, 1933, p.57. u-kai. Mulher (banto).

Dornas Fo, 1938, p.148. ocaia. Mulher (or. quimbunda).

OCAIA OCORA [o'kajə o'korə]. Mãe (lit. mulher velha).

OCAIA DO CUETE [o'kajo du 'kwetfi]. Esposa (lit. mulher do homem). 
OCAIA DE CUXIPA. [o'kajə dzi ku'Sipə]. Prostituta (lit. mulher da boceta). OCAIA DE IMBUNDA [ə’kajə dzi ı̃'bũdə]. 1. Feiticeira. 2. Mulher infiel (lit. mulher de ambundo).

OCAIA MEU TATA [ə'kajə 'mew 'tatə]. Mãe (lit. mulher meu genitor).

OCAINHA [oka'iñ]. S.m. ou f. 1. Menina. Tipura a ocainha! Olha a menina! 2. Mocinha. A ocainha é catita. Ocainha é boa demais. A mocinha é nova. A mocinha é boa demais.

OCAIZIM [okaj'zi1]. S.m. ou f. 1. Menina. 2. Mocinha.

OCAIZINHA [okaj'zĩnə]. S.m. ou f. 1. Menina. 2. Mocinha.

OCORA [0'korə]. Adj. 1. Velho. O conjolo é ocora. A casa é velha. S.m. ou f. 2. Homem velho. Quem gosta de ocora é só o conjolo dos granjão. Quem gosta de velho é só igreja. 3. Velho, genitor. Vô lá vê minha ocora. Vô lá vê minha velha.

Dornas Fo, 1938 , p.145. ocóca. Velho (or. quimbunda).

OLI [o'li]. S. Branco.

OMENHA [ơ'mẽn]], OMÉM [ơ'mẽỹ]. S.m. ou f. 1. Água. Seu orangê é a prova de omém. Seu cabelo é a prova d'água. 2. Chuva. Eu fiquei com a minha urunanga toda catita, porque a omenha injirava na minha urunanga. Eu fiquei com a minha ropa toda encolhida, porque a chuva caía na minha ropa. 3. Urina. Eu caxei muito foi omém. Eu fiz muito xixi. 4. Sangue. O otro machucô o cafuvira (...), tirô a omém (...) no cuete assim. O otro machucô o preto (...), tirô o sangue no cara assim.

Cannecattim, 1859, p.7. omenha. Água (bundo).

LANG, 1906, p.99. omeva. Água (nhaneca).

Dornas Fo, 1938, p.148. omenha. Água (or. quimbunda).

Machado Fo, 1964, p.123. omenhá. Água.

OMENHA AVURA [ơ'mẽnə a’vurə]. Rio, lagoa, córrego (lit. água muita).

OMENHA DE VIANJÊ [õ’mẽnə dzi viã’ze]. Cachaça (lit. água de cana).

OMENHA CAXÁ [õ'mẽno ka'Ja]. Chover (lit. água cair). Fui curimbá hoje com as ocaia, entendeu? Chegô lá, o omenha acaxô avura, sabe? Fui trabalhá hoje com as mulhé, entendeu? Chegô lá, choveu muito, sabe? CAXÁ OMENHA [ka'ja õ'mẽnə]. 1. Urinar. 2. Chorar (lit. fazer água). TIPURÁ A OMENHA [tfipu'ra a õ'mẽnə]. Urinar (lit. fazer a água).

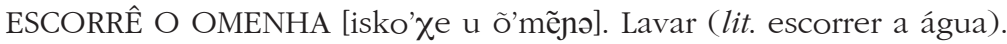
COR DO OMENHA ['ko $\chi$ du ô'mẽnə]. Branco (lit. cor da água).

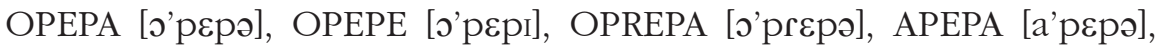
APEPE [a'pepi], ATLEBA [a'tlebə]. Adj. Bonito. Ela tem é um conjô de matuaba muito opepa. Ela tem é um bar muito bonito. 
ORANJÊ [orã'ze], ARANJÊ [arã'ze]. S.m. ou f. 1. Cabelo. Comé que é o oranjê da ocaia? Comé que é o cabelo da mulhé? 2. Barba. A oranjê do cuete tá avura. A barba do cara tá grande. 3. Bigode.

Dornas $\mathrm{F}^{\mathrm{O}}$, 1938, p.148. orangê. Testa (or. quimbunda).

Machado Fo, 1964, p.123. onjorê. Cabelo.

ORANJÊ DE CANGURA [orã'ze dzi kã'gurə]. Pixaim, carapinha (lit. cabelo de porco).

ORANJÊ DE OMENHA [orã'ze dzi õ'mẽnə]. Cabelo liso, escorrido (lit. cabelo de água).

ORANJÊ DE CABEÇA DE GEADA [orã'ze dzi ka'besə dzi zi'adə]. Cabelo branco (lit. cabelo de cabeça de geada).

ORANJEZIM [orãze'zĩ]. S.m. Cabelinho. Eu gosto bem dum oranjezim avura, viu? Eu gosto bem dum cabelinho grande, viu?

ORELO [o'rclu], ORELA [o'rclə]. S.m. ou f. Gordura. Ma essa cuete tem muita orela nos tinhame, num tem? Ma essa menina tem muita gordura nas perna, num tem?

Dornas Fo, 1938 , p.148. orelá. Toucinho (or. quimbunda).

Machado Fo ${ }^{\circ}$ 1964, p.123. orerá. Toucinho.

ORELO DE GOMBÊ [o'relu dzi gõ'be]. Manteiga (lit. gordura de vaca).

ORONGÓ [orÕ'go], ORANGÓ [orã'go], ORONGOME [orõ'gÕmi], ARONGÓ [arõ'go], ARANGOME [arã'gõmi], ARANGUÃO [arã'gwãw]]. S.m. Cavalo. Aí, ó, orongome (...) caxano imbuete. Aí, ó, o cavalo (...) carregando lenha.

Dornas Fo, 1938, p.148. orangôlo. Cavalo, égua (or. quimbunda).

ORUFIM [oru'fĩ], ORUFINO [oru'fĩ nu], OUROFINO [owru'fĩnu], URUFIM [uru'fĩ]. S.m. Peixe. Urufim avura tamém caxa. Peixe grande tamém tem.

Lang, 1906, p.103. onohi. Peixes (nhaneca).

Dornas Fo, 1938, p.148-149. orossi, uruxi. Peixe (or. quimbunda).

Ibidem. p.149. uruxi. Peixe.

CAXÁ ORUFIM [ka'Ja oru'fĩ ]. Pescar (lit. pegar peixe). Tava caxano orufim. Tava pescano.

ORUM [o'rũ], ORUMO [o'rũmu], ORUME [o'rũmi], ORUMA [o'rũmə], URUM [u'rũ], URUMO [u'rũmu], URUMA [u'rũmo]. S. 1. Carro. Caxô de uruma até a entrada do cumbara. Veio de carro até a entrada da cidade. 2. Máquina.

Dornas $\mathrm{F}^{\circ}$, 1938, p.148. orume. Trem de ferro (or. quimbunda).

ORUM AVURA [o'rũ a'vurə]. Caminhão (lit. carro grande). 
ORUM CATITO [o'rũ ka’tfitu]. 1. Automóvel. 2. Bicicleta (lit. carro pequeno). ORUM DE GOMBÊ [o'rũ dzi gõ'be]. Carro de boi (lit. carro de boi).

ORUM DO MAVERA [o'rũ du ma'verə]. Carro leiteiro (lit. carro do leite).

ORUM DE ORONGÓ [o'rũ dzi orõ'go]. Carroça (lit. carro de cavalo).

ORUM DO TEMPO [o’rũ du 'tẽpu]. Relógio (lit. máquina do tempo).

ORUM DE UNDARA [o'rũ dzi ũ'darə]. Aparelho elétrico (lit. máquina de fogo).

ORUM DAS/DE URUNANGA [o'rũ daz/dzi urũ'nãgə]. Máquina de costura (lit. máquina das/de roupa).

ORUM PRETO [o’rũ 'pretu]. Telefone (lit. máquina preta).

ORUMIM [orũ'mĩ], URUMIM [urũ'mĩ]. S.m. Carrinho. Orumim catito do cumbara avura. Carrinho pequeno da cidade grande.

OTEQUE [o’teki], CONTEQUE [kõ’teki]. S.m. Noite.

Dornas $\mathrm{F}^{\mathrm{o}}$, 1938, p.148. otecame, otéque. Noite (or. quimbunda).

Machado $\mathrm{F}^{\mathrm{o}}$, 1964, p.124. otequê. Dia.

$$
\mathrm{P}
$$

PRANCHEIO [prã'Seju]. S.m. Queda.

PRANCHIÁ [prãsi'a]. V. 1. Cair. A hora que eu bati o tiparo lá fora assim, eu vi a imbera pranchiano, falei: Nossa senhora! A hora que eu bati o olho lá fora assim, eu vi a chuva caíno, falei: Nossa Senhora! 2. Escorregar. Pranchiô e caiu. Escorregou e caiu.

PROTIUDA [pro'tsiwdə], PROTIUDE [pro'tsiwdzi]. S.f. Nádegas. 2. Órgão sexual feminino.

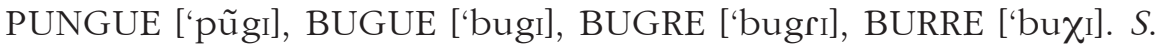
Milho.

LANG, 1906, p.100. epungu. Milho (nhaneca).

PÓ DE PUNGUE ['po dzi 'pũgi]. 1. Farinha de milho (lit. pó de milho). $A h$, nóis temo que curiá o assango memo, com camberela, tipoquê, pó de pungue. Ah, nóis temo que comê o arroiz memo, com carne, feijão, farinha de milho. 2. Fubá.

$\mathrm{R}$

RADIOPIPA [Хadzjo'pipə]. S.f. Nádegas. Uma radiopipa que eu vô te contá. Uma bunda que eu vô te contá. 
SABOR [sa'box]. S.m. Ovo.

SENGUE ['sẽgi], SENGO ['sẽgu]. S.m. Mato. Se esse cuete injirá com essa ocaia pro sengue, eu vô caxá nele imbuete. Se esse cara fô com essa mulhé pro mato, eu vô metê o pau nele.

Dornas Fo , 1938, p.148-149. ossenguê, sengue. Mato (or. quimbunda).

Machado Fo, 1964, p.125. senguê. Mato.

INJIRÁ PO SENGUE COM OS CAMBUÁ [ỉi'ra pu 'sẽgi kõ us kãbu'a]. Caçar (lit. ir para o mato com os cachorros).

$\mathrm{T}$

TATA ['tatə], OTATA [o'tatə]. S.m. Genitor.

Cannecattim, 1859, p.9. táta. Pai (bundo).

LANG, 1906, p.106. tate. Pai, padrasto (nhaneca).

Dornas Fo, 1938, p.149. tatá. Pai (or. quimbunda).

Castro, 1978, p.5. tateto. Pai, pai-de-santo.

Vogt, Gnerre, 1978, p.13. tata. Pai.

TEIA ['tejə]. S.m. Tatu. Fomo caxá o teia no jiqui, no conjô dele (...). Fomo caça o tatu no buraco, na casa dele (...).

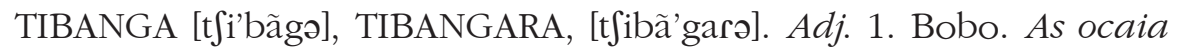
aqui até num é tibangara não, né? As mulhé aqui até num é boba não, né? 2. Triste.

MACHADO Fo, 1964, p.130. sumbanga. (Pessoa) insignificante.

TIBANGÃO [t]ibã'gãw̃]. Adj. Bobão. Ele num é do arto, ele num tipura nada não, sô. Ele é tibangão do sengue. Ele num é do arto, ele num fala nada não, sô. Ele é bobão do mato.

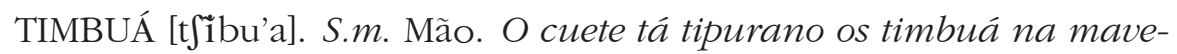
ra da ocaia. O cara tá passano as mão no peito da mulhé.

Tinhamão [t]ĩnã'mãw̃]. S.m. 1. Pernão. 2. Pé grande. 3. Mão grande.

TINHAME [t]1’’nãmi], QUINAME [ki'nãmi]. S.m. 1. Perna. Tinhame da ocaia é avura. A perna da mulhé é bonita. 2. Pé. Tiproque no tinhame. 
Sapato no pé. 3. Mão. Vai te socá o quiname no tué. Vai te socá a mão na cabeça.

Cannecattim, 1859. p.9. quinama. Pé, perna (bundo).

Dornas Fo, 1938. p.149-150. quinhama, vinhama. Pé, perna (or. quimbunda).

TINHAME CATITO [ț1̃’nãmi ka’titu]. Pé (lit. perna pequena).

TINHAME DE INJIRA [t]1’’nãmı dzi î̉zirə]. 1. Perna. 2. Pé (lit. perna de caminho).

TINHAME DE ORUM [t]1'jãmi dzi o'rũ]. Roda de carro (lit. perna de carne ou pé de carro). Ah, mais tamém tem um tinhame que num vale um tinhame de uruma. Ah, mais tamém tem uma perna que num vale uma roda de carro.

NO TINHAME [nu tjỉ’nãmi]. A pé (lit. no pé). No tinhame a ocaia num vai injirá com o sinhô memo, cuete. A pé a mulhé num vai saí com o sinhô memo, cara.

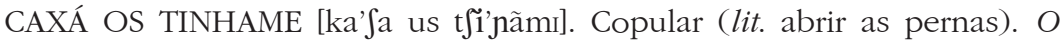
cuete cafuvira caxô os tinhame da ocaia lá no sengue. O cara preto comeu a mulhé lá no mato.

TIPARÊ [t]ipa're]. S.m. Olhar.

TIPARA [t]i'parə], TIPARO [t]i'paru], TIPAR [t]i'pax]. S.m. 1. Olho. O cuete desse orum catito aí ó, passô meteno os tipara no meu conjolo. O cara desse carrinho aí ó, passô meteno os óio na minha casa. 2. Semblante, cara. O cuete cavinguero é o tipara do cuete. O patrão é a cara do cara.

LANG, 1906, p.105. otyipala. Rosto (nhaneca).

TIPARA DE MAVERA [t]i'parə dzi ma'verə]. Branco (lit. cara de leite).

COM OS TIPARA ARRIBA [kõ us tfi'parə a'Xibə]. Atento, com atenção (lit. com os olhos arriba). Pode ficá com o tué uarrufo e os tipara arriba porque o negócio aqui num tá brincadera não. Pode tomá cuidado e prestá atenção, porque o negócio aqui num tá brincadera não.

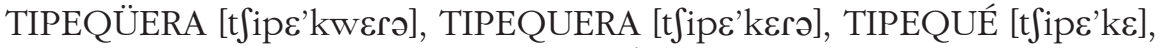

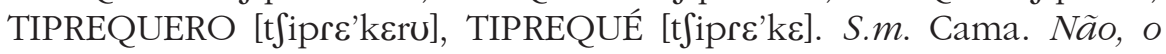
negócio é tipequera no sengue memo, uai. Não, o negócio é cama no mato memo, uai.

Dornas Fo, 1938, p.146. cachico cupequéra. Dormir (or. quimbunda).

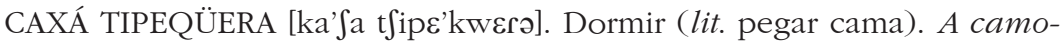
ninha tava caxano tipeqüera quando o cuete cafuvira injirô e caxô nela a omenha. A menina tava dormino quando o cara preto veio e jogô água nela.

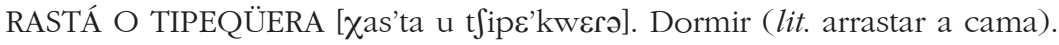
Eu rastei tipeqüera cedim. Eu dormi cedim. 
TIPURÁ O TIPEQÜERA [t tipu'ra u t tipe'kwerə]. 1. Dormir (lit. pegar a cama). (Eles) tipurô o tipeqüera no isquife avura (...) sem urunanga (...) catita e avura e eles mexeu no cuxipo. (Eles) dormiu na cama grande (...) sem roupa (...) nenhuma e meteu.

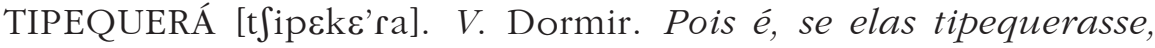
os cuete avura injirasse no curimbo... Pois é, se elas dormisse e os patrão chegasse no trabalho...

DORnas Fo, 1938 , p.146. chapaquerá measso. Dormir (or. quimbunda). Machado Fo, 1964, p.120. copequera. Dormir.

TIPOMO [t]i’põmu], TICOMO [t]i'kõmu], PONGO ['põgu]. S.m. Chapéu. Dornas Fo, 1938 , p.148-149. pungo, tipungo. Chapéu (or. quimbunda). Machado $\mathrm{F}^{\mathrm{o}}$, 1964, p.124. quipungo. Chapéu. TIPOMO NO TUÉ [ti'põmu nu tu'e]. Chapéu (lit. chapéu na cabeça).

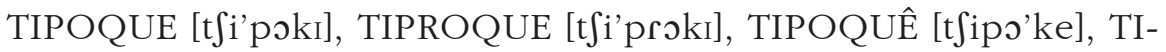
POQUERO [t]ipo'keru]. S.m. Feijão. Ab, nóis temo que curiá o assango memo, com camberela, tipoque, pó de bugue. Ah, nóis temo que cumê o arroz memo, com carne, fejão, farinha de milho.

LANG, 1906, p.100. otyipoke. Feijão (nhaneca).

Dornas Fo, 1938, p.149. tipoquê. Feijão (or. quimbunda).

Castro, 1978, p.10. quipoke, tipoke, cipoke. Feijão.

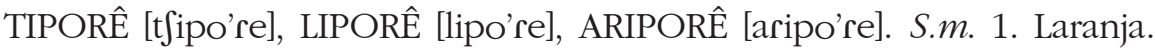
2. Limão. Um liporê com sal. Um limão com sal.

Dornas Fơ , 1938, p.145. aporé, mapôra. Laranja (or. quimbunda). Ibidem. p.147-149. maporé, uaporé. Fruta (or. quimbunda).

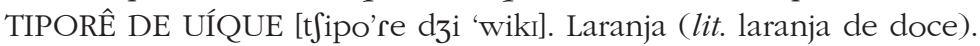

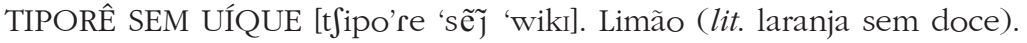

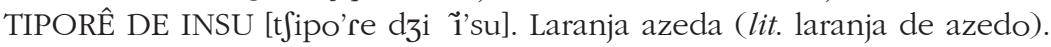

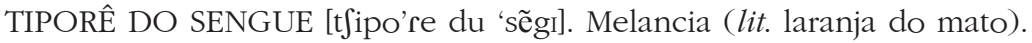
TIPOREZIM [t]ipore'z̃i]. S.m. Limãozinho. Tipura pra vê se o cuete acaxa um tiporezim acatito. Vê lá se o cara traz um limãozinho.

TIPROQUE [t Jiproki], TIPLOQUE [t]i'ploki]. S.m. Calçado, sapato. Pior que o meu tiploque tá furado. O pior é que o meu sapato tá furado.

TIPURÁ [t $\left.\int i p u ' r a\right] . ~ V$. Olhar, ver, entender, saber, falar, flertar, pegar, possuir, apreciar etc. Funciona como um verbo passe-partout cujo sentido se define pelo contexto, verbal e situacional. Tipura a ocaia! A o longado da ocaia. Olha a mulhé! A o rebolado da mulhé. Dá pa tipurá com o cuete do conjolo pa tipurá o mungo pa nóis? Dá pa falá 
com o cara do bar pa trazê o sal pa nóis? O cuete ocora gosta de tipurá muito com as ocaia. O velho gosta de paquerá muito com as mulhé. TIPURÁ A CENA [t Tipu'ra a 'sẽnə]. 1. Entender (lit. olhar a cena). Camonim tipura a cena. O menino entende. 2. Ter ligação amorosa, pop. transar (lit. fazer a cena).

TIPURADA [t $\mathrm{tipu} r a d ə]$. S.f. 1. Olhada, olhadela. Há poco tempo eu tipurei, dei uma tipurada (...), eu tava com oito ocaia esperano camonim. Há poco tempo eu olhei, dei uma olhada (...), eu tava com oito mulhé esperano neném. 2. Sarro, bolinagem. Aquele dia que eu tipurei ocê lá, ela falô que ia te dá umas garrada boa, umas tipurada boa com cê. Aquele dia que eu vi ocê lá, ela falô que ia te dá umas garrada boa, uns sarro bom com cê.

TUÉ [tu'e]. S.m. Cabeça. Pois é, ele tem o tué mei avura, né? Pois é, ele tem a cabeça mei grande, né?

Cannecattim, 1859, p.8. mutué. Cabeça, testa (bundo).

LANG, 1906, p.105. omutwe. Cabeça (nhaneca).

Dornas Fo, 1938, p.150. utuê. Cabeça, testa (or. quimbunda).

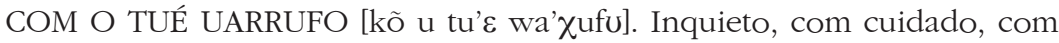
atenção (lit. com a cabeça brava). Pode ficá com o tué uarrufo e os tiparo arriba, porque o negócio aqui num tá brincadera não. Pode tomá cuidado e prestá atenção, porque o negócio aqui num tá brincadera não.

TUEZÃO [tuє'zãã)]. S.m. Cabeção. Dexa pra lá, uai, dexa aquele tuezão dele prá lá. Dexa pra lá, uai, dexa aquele cabeção dele pra lá.

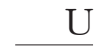

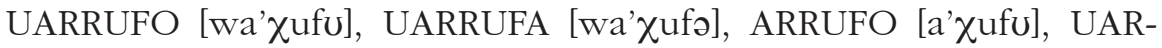

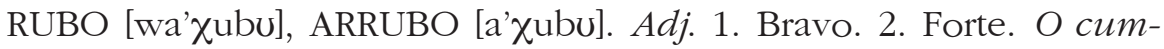
ba tá arrufo. O sol tá forte. 3. Grande. O tinhame dele é uarrufo. O pé dele é grande.

UBA ['ubə]. S.f. 1. Cerveja. Dá pra saí a uba pra nóis aî? Dá pra saí a cerveja pra nóis aî? 2. Cachaça.

UÍQUE [w'iki], UÍGUE [u'igi]. S.m. Açúcar. (...) caxaro um cajuvira lá, ma o cajuvira num tinha uíque não, uai. (...) serviro um café lá, ma o café num tinha açúca não, uai. 2. Doce.

Cannecattim, 1859, p.150. uiqui. Açúcar, doce, mel (conguês).

Ibidem. p.150. uíqui, guiqui. Açúcar, doce, mel (bundo). 
Lang, 1906, p.107. owiki. Mel (nhaneca).

Dornas Fo, 1938, p.149. uique. Açúcar, doce, mel, rapadura.

Vogt et al. 1980, p.30. wiki. Açúcar, doce, mel.

UNDARA [ũ'darə], UNDARO [ũ'daru], SUNDARO [sũ'daru], INDARO [î'daru]. S.m. 1. Fogo. Ma caxava ele (o tipoquê) no undara, uai. Ma secava ele (o fejão) no fogo, uai. 2. Ouro. Eu caxo undara no injequê. Cê tamém caxa? Eu tenho ouro na boca. Cê tamém tem? DORNAS Fo, 1938, p.145-150. anduro, undaro. Fogo (or. quimbunda). Machado Fo, 1964, p.111-123. anduro, ondara. Fogo.

FrY, 1982, p.120. andaru. Fogo.

DE UNDARA [dzi ũ'darə]. Bêbado (lit. de fogo).

UNDE [ũdzi]. S.m. Sol.

URUFACO [uru'faku], URUVACO [uru'vaku]. S.m. Calçado, sapato. Qualqué urufaco serve nele. Qualqué calçado serve nele.

URUNANGA [urũ'nãgə], URUNDANGA [urũ'dãgə], ARUNANGA [arũ'nãgə], ARUNDANGA [arũ'dãgə]. S.f. 1. Roupa. A ocaia tipurô no isquife avura, sabe?, sem a urunanga, e o camonim injirô. A mulhê deitô na cama grande, sabe?, sem a ropa, e ficô grávida.

Dornas Fo , 1938, p.148. oronanga. Roupa (or. quimbunda).

Ibidem. p.149. urunanga. Calça (or. quimbunda).

Machado Fo, 1964, p.123. oronanga. Roupa.

Vogt et al. 1980, p.30. nãga. Roupa.

URUNANGA AVURA [urũ'nãgə a'vurə]. Camisola (lit. roupa grande).

URUNANGA CATITA [urũ'nãgə ka'tfitə]. Calcinha (lit. roupa pequena).

URUNANGA DE GOMBÊ [urũ'nãgə dzi gõ'be]. Tambor (lit. roupa de boi).

Óia aquela urunanga de gombê cumé que tá uarrufo, ó. Óia aquele tambor comé que tá forte, ó.

URUNANGA DE TIPURÁ OS MAVERA [urũ'nãgə dzi t tipu'ra uz ma'verə]. Sutiã (lit. roupa de segurar os seios).

CAXÁ URUNANGA NA OMENHA [ka'`a urũ'nãgə na õ'mẽjə]. Lavar roupa (lit. pôr roupa na água). Eu vô caxá urunanga na omém, num tem jeito não. Eu vô lavá roupa, num tem jeito não.

V

VIANJÊ [viã'ze]. S. Cana.

Dornas $\mathrm{F}^{\mathrm{o}}$, 1938, p.150. vienguê. Cana (or. quimbunda). 
VIRIANGO [viri'ãgu]. S.m. Soldado. O oranjê dele é catito, né não? Alá ô, tá pareceno viriango. O cabelo dele é pequeno, né não? Alá ó, tá pareceno soldado.

VIRU [vi'ru]. S.m. Defunto. Injirô atrais dele (...). Depois: Num injira não que eu te meto um muque de undara e faço um viru docê. Correu atrais dele (...). Depois: Num corre não que eu te meto uma bala e faço um defunto docê.

FITÁ VIRU [fi'ta vi'ru]. Morrer (lit. fitar defunto).

VIZUNGA [vi'zũgə]. S. Baile.

Machado Fo ${ }^{\circ}$ 1964, p.126. vissungo. Cantiga, especialmente de mineração.

$\mathrm{X}$

XAPIXAPE [Sapi'Japı]. S.m. Comida. 


\section{REFER E N C I A S B I B L IO G R ÁF I C A S}

ALVES, Henrique L. Bibliografia afro-brasileira; estudos sobre o negro. 2.ed. rev. e ampl. Rio de Janeiro/Brasília: Cátedra/INL, 1979 .

AMARAL, Amadeu. O dialeto caipira. 3.ed. São Paulo: HUCITEC/ Secretaria da Cultura, Ciência e Tecnologia, 1976.

ANOTAÇÕES feitas para um trabalho da disciplina de Sociologia do Curso de Comunicação Social da FAFICH/UFMG, por Cristina Sá Motta Pinheiro e Ângela Machado Linhares. Belo Horizonte, $2^{\underline{o}}$ sem. 1977.

AZEVEDO, Thales de. Uma nova negritude no Brasil? Cultura, Brasília, v.6, n.23, p.118-128, out./dez. 1976.

BATINGA, Gastão. Aspectos da presença do negro no Triângulo Mineiro/Alto Paranaíba: Kalunga. Uberlândia: Ed. do autor, 1994.

BARBOSA, Waldemar de Almeida. Negros e quilombos em Minas Gerais. Belo Horizonte: [Imprensa Oficial], 1972.

BECHARA, Evanildo. Moderna gramática da lingua portuguesa. São Paulo: Companhia Editora Nacional, [s.d.].

BONVINI, Emilio. "Classes d'accord" dans les langues négro-africaines: un trait typologique du Niger-Congo - exemples du kasim et du kimbundu. Faits de Langues: l'accord, n.8, p.77-88, 1996.

BRAM, Joseph. Linguagem e sociedade. Trad. Yolanda Giudicelli. Rio de Janeiro: Bloch, 1968. (Col. Uniblock).

BRANDÃO, Adelino. Contribuições afro-negras ao léxico popular brasileiro. Revista Brasileira de Folclore, Rio de Janeiro, MEC, Campanha de Defesa do Folclore Brasileiro, v.8, n.21, p.119128, maio/ago. 1968. 
BRANDÃO, Carlos Rodrigues. Congos, congadas e reinados: rituais de negros católicos. Cultura, Brasília, v.6, n.23, p.78-93, out./dez. 1976.

BRASIL. Museu Nacional. Divisão de Antropologia. Setor Lingüístico. Formulário dos vocabulários padrões para estudos comparativos preliminares nas linguas indigenas brasileiras. 2.ed. Rio de Janeiro, 1960.

BUNSE, Heinrich Adam Wilhelm. São José do Norte; aspectos lingüístico-etnográficos do antigo município. 2.ed. Porto Alegre: Mercado Aberto/Instituto Estadual do Livro, 1981.

BYRD, Steven Eric. Calunga, an Afro-Brazilian Speech of the Triângulo Mineiro: Its Grammar and History. 2005. 1 v. Dissertation (Doctorate of Philosophy) - University of Texas at Austin, 2005.

CÂMARA JÚNIOR, J. Mattoso. Dicionário de lingüistica e gramática. Petrópolis: Vozes, 1977.

CÂMARA JÚNIOR, J. Mattoso. Estrutura da lingua portuguesa. 8.ed. Petrópolis: Vozes, 1977.

CÂMARA JÚNIOR, J. Mattoso. Introdução às linguas indígenas brasileiras. Rio de Janeiro: Ao livro técnico, 1979.

CÂMARA JÚNIOR, J. Mattoso. Manual de transcrição fonética. Rio de Janeiro: Universidade do Brasil/Museu Nacional, 1957. (Manuais do Museu Nacional, Série A, 2).

CÂMARA JÚNIOR, J. Mattoso. Para o estudo da fonêmica portuguesa. 2.ed. Rio de Janeiro: Padrão, 1977.

CÂMARA JÚNIOR, J. Mattoso. Problemas de lingüistica descritiva. 6.ed. Petrópolis: Vozes, 1973.

O CAMINHO empoeirado do difícil desenvolvimento do Norte de Minas. Estado de Minas, Belo Horizonte, 24 abr.1983. Economia, p.1.

CANNECATTIM, Fr. Bernardo Maria de. Collecção de observações grammaticaes sobre a lingua bunda ou angolense e diccionario abreviado da lingua congueza. 2.ed. Lisboa: Imprensa Nacional, 1859.

CARNEIRO, Edison. Antologia do negro brasileiro. Porto Alegre/São Paulo: Globo, 1950. 
CARNEIRO, Edison. Ladinos e crioulos; estudos sobre o negro no Brasil. Rio de Janeiro: Civilização Brasileira, 1964. P.37-41: A costa da mina. (Retratos do Brasil, 28).

CARNEIRO, Edison. Religiões negras: notas de etnografia religiosa; Negros bantos: notas de etnografia religiosa e de folclore. 2.ed. Rio de Janeiro/Brasília: Civilização Brasileira/INL, 1981. P.110-113: Nação nagô, cadê tua língua? (Retratos do Brasil, 153).

CARNEIRO, Edison. O negro em Minas Gerais. Separata do Boletim do Centro Brasileiro de Pesquisas Educacionais, Rio de Janeiro, MEC/INEB/CBPE, p.3-18, [s.d.].

CARVALHO, Felix de. Falares crioulos do Brasil; um tema em debate. Rio de Janeiro: Departamento de Letras da PUC/RJ, 1977. (Dissertação, Mestrado em Lingüística. Inédita).

CASTRO, Yeda P. de. África descoberta: uma história recontada. Separata da Revista de Antropologia, São Paulo, USP - Faculdade de Filosofia, Letras e Ciências Humanas, Departamento de Ciências Sociais, v.23, p.135-140, 1980.

CASTRO, Yeda P. de. Os falares africanos na interação social dos primeiros séculos. In: CONGRESSO BRASILEIRO DE SÓCIO E ETNOlingüÍSTICA, 1, João Pessoa. Anais... João Pessoa: UFPB, 1978. (Mimeogr.).

CASTRO, Yeda P. de. Influências de línguas africanas no português do Brasil e níveis sócio-culturais de linguagem. Educação, Brasília, v.6, n.25, p.49-64, out./dez. 1977.

CASTRO, Yeda P. de. Níveis sociolingüísticos da integração de influências africanas no português. In: ENCONTRO NACIONAL DE LINGÜÍSTICA, 3, 1978, Rio de Janeiro. Conferências... Rio de Janeiro: PUC/RJ, 1978. p.18-21.

CASTRO, Yeda P. de. A presença cultural negro-africana no Brasil: mito e realidade. Ensaios/Pesquisas, Salvador, n.10, jul. 1981.

CASTRO, Yeda P. de, CASTRO, Guilherme A. de Souza. Culturas africanas nas américas: um esboço de pesquisa conjunta da localização de empréstimos. Afro-Ásia, Salvador, n.13, p.27-50, abr. 1980 . 
CIENTISTAS da UFJF descobrem uma tribo de africanos perto do Serro. Estado de Minas, Belo Horizonte, 25 maio 1976.

COARACY, Vivaldo. Escravos para as Minas Gerais. In: CARNEIRO, Edison. Antologia do negro brasileiro. Porto Alegre/ São Paulo: Globo, 1950. p.99-100.

COELHO, F. Adolfo et al. Crioulos; introdução e notas de Jorge Morais-Barbosa. Lisboa: Academia Internacional da Cultura Portuguesa, 1967.

COISAS de Bom Despacho. O Bom Despacho, Bom Despacho, p.1, 6 nov. 1977.

CONRAD, Robert. Brasilian Slavery: an annotated Research Bibliography. Boston: G. K. Hall, 1977.

COUCEIRO, Solange Martins. Bibliografia sobre o negro brasileiro. 2.ed. São Paulo: Centro de Estudos Africanos/CODAC/USP, 1974.

COUTINHO, Ismael de Lima. Pontos de gramática bistórica. 6.ed. rev. Rio de Janeiro: Acadêmica, 1974. P.324-325: O português; o elemento africano.

CUNHA, Celso. Gramática do português contemporâneo. 5.ed. Belo Horizonte: Bernardo Álvares, 1975.

CUVILLIER, Armand. Sociologia da cultura. Trad. Leonel Vallandro. São Paulo/Porto Alegre: EDUSP/Globo, 1975. Cap.2: Sociologia da linguagem e da escrita, p.174-247.

DORNAS FILHO, João. Vocabulário quimbundo. Revista do Arquivo Municipal, [São Paulo], v.49, n.5, p.143-150, jul./ago. 1938.

ELIA, Sílvio. A unidade lingüistica do Brasil; condicionamentos geoeconômicos. Rio de Janeiro: Padrão, 1979.

ELSON, Benjamim, PICKETT, Velma. Introdução à morfologia e à sintaxe. 2.ed. Trad. Aryon D. Rodrigues et al. Petrópolis: Vozes, 1978.

EMMERICH, Charlotte. Um traço propulsor numa língua de contato. In: ENCONTRO NACIONAL DE LINGÜÍSTICA, 1977, Rio de Janeiro. Conferências... Rio de Janeiro: PUC, 1977. (Mimeogr.). 
ENCONTRO NACIONAL DE CENTROS DE ESTUDOS AFROBRASILEIROS, 1, 1981, Belo Horizonte. Objetivos. Belo Horizonte: FAFICH/UFMG, 1981. (Mimeogr.).

ESTADO DE MINAS GERAIS. Secretaria da Agricultura. Serviço de Estatística Geral. Minas segundo o recenseamento de 1920. Belo Horizonte: Imprensa Oficial, 1924.

FERREIRA, Jurandyr Pires (Plan. e Org.). Enciclopédia dos municipios brasileiros. Rio de Janeiro: IBGE, 1958. v.24, p.205-208.

FISHMAN, Joshua A. The sociology of language: an interdisciplinary social science approach to language in society. Massachussetts: Rowley/Newburry House Publishers, 1972.

FONSECA, Maria Stella V., NEVES, Moema F. (Org.). Sociolingüística. Rio de Janeiro: Eldorado, 1974. (Col. Enfoque).

FREYRE, Gilberto. Aspectos da influência africana no Brasil. Cultura, Brasília, v.23, n.6, p.6-19, out./dez. 1976.

FRY, Peter, VOGT, Carlos, GNERRE, Maurizio. Mafambura e caxapura: na encruzilhada da identidade. In: FRY, Peter. Para inglês ver; identidade e política na cultura brasileira. Rio de Janeiro: Zahar, 1982. p.116-135.

GARCIA, Rodolfo. Vocabulário nagô. In: MENDONÇA, Renato et al. Estudos afro-brasileiros; trabalhos apresentados ao $1^{\circ}$ Congresso Afro-Brasileiro reunido no Recife em 1934. Rio de Janeiro: Ariel, 1935. v.1. p.21-27.

GAMADI, Juliette. Introdução à sociolingüistica. Trad. Eugénio Cavalheiro. Lisboa: Dom Quixote, 1983. (Col. Universidade Moderna, 78).

GNERRE, Maurizio. O corpus dos vissungos de São João da Chapada $(M G)$. [Campinas]: [s.n.], [198-]. (Cópia xerográfica. Inédito).

GNERRE, Maurizio. Um pidgin espanhol da amazônia pré-andina. In: SEGUNDO ENCONTRO NACIONAL DE LINGÜÍSTICA. Rio de Janeiro, 2, 1977. Conferências... Rio de Janeiro: PUC, 1977. (Mimeogr.). 
GNERRE, Maurizio, FRY, Peter, VOGT, Carlos. Cafundó: creole(?) death or change? [Campinas]: [s.n.], [198-]. (Inédito).

GÓIS, Carlos. Diccionario de affixos, desinencias e outros elementos de composição. Rio de Janeiro: F. Briguiet, 1913.

GOLGHER, Isaías. O negro e a mineração em Minas Gerais. Separata da Revista Brasileira de Estudos Políticos, Belo Horizonte, n.18, p.133-150, 1965.

GONZALES, Lélia, HASENBALG, Carlos. Lugar do negro. Rio de Janeiro: Marco Zero, 1982. (Col. Dois Pontos, 3).

GOUGE NHEIM, G., RIVENC, P., MICHÉA, R., SAUVAGEOT, A. L'élaboration du français fondamental ( $1^{\mathrm{er}}$ degré). Étude sur l'établissement d'un vocabulaire et d'une grammaire de base. 2.ed. refondue et augmentée. Paris: Didier, 1964.

GUILBERT, Louis. La créativité lexicale. Paris: Larousse, 1975. (Col. Langue et Langage).

GUIRAUD, Pierre. L'argot. Paris: Presses Universitaires de France, 1958. (Col. Que Sais-je?, 700).

HOUAISS, Antônio. Socio- e etnolingüística. In: CONGRESSO NACIONAL DE SOCIO- E ETNOLINGÜÍSTICA, 2, 1980, Niterói. Comunicações... Niterói: UFF, 28 jul. 1980.

IBGE. Depto. de Estatísticas de População de Minas Gerais. Censo demográfico de 1960. VII Recenseamento geral do Brasil. (Série regional, v.1, t.9).

IBGE. Conselho Nacional de Estado. Serviço Nacional de Recenseamento. Estado de Minas Gerais. Censo demográfico de 1950. Rio de Janeiro, 1954. (Série regional, v. 22, t.1).

IBGE. Censo demográfico de 1940. [s.n.t.].

IBGE. Município de Bom Despacho; informações básicas. 1978. [s.n.t.].

IBGE. Recenseamento geral de 1890. [s.n.t.]. 
IBGE. Recenseamento geral de 1872. [s.n.t.].

IBGE. Serviço Nacional de Recenseamento. VII Recenseamento geral do Brasil - 1960. Sinopse preliminar do censo demográfico. Rio de Janeiro: Serviço gráfico IBGE, 1962.

JAKOBSON, Roman. Fonema e fonologia. Trad. J. Mattoso Câmara Jr. Rio de Janeiro: Livraria Acadêmica, 1972.

JESPERSEN, Otto. Humanidad, nación, individuo desde el punto de vista lingüístico. Trad. Fernando Vela. Buenos Aires: Revista de Occidente Argentina, 1947.

LANG, Affonso Maria. Ensaios de gramática nyaneka. Lisboa: Minerva Lusitana, 1906.

LAYTANO, Dante de. Os africanismos do dialeto gaúcho. Separata da Revista do Instituto Histórico e Geográfico do Rio Grande do Sul, Porto Alegre, v.16, n.2, p.7-66, 1936.

LINHARES, Ângela Machado, PINHEIRO, Cristina Sá Motta. Anotações feitas para um trabalho da disciplina Sociologia. Belo Horizonte: FAFICH/UFMG, 1977. (Notas de aula).

LÚCIO, João, FROTA, Zilah. O livro de Violeta. Rio de Janeiro: Francisco Alves, 1959.

LUNA, Francisco Vidal, COSTA, Iraci del Nero da. A presença do elemento sudanês nas Minas Gerais. O Estado de S.Paulo, São Paulo, 2 mar. 1980. Suplemento cultural, v.4, n.174, p.6-7.

MACHADO FILHO, Aires da Mata. O negro e o garimpo em Minas Gerais. 2.ed. Rio de Janeiro: Civilização Brasileira, 1964. (Retratos do Brasil, 26).

MALHEIRO, Perdigão. A escravidão no Brasil; ensaio histórico, jurídico e social. 3.ed. Petrópolis/Brasília: INL/Vozes, 1976. v.2. (Dimensões do Brasil, 3).

MARTINET, André. Elementos de lingüistica geral. 6.ed. Trad. adap. Jorge Morais-Barbosa. Lisboa: Martins Fontes/Sá da Costa, 1975. 
MARTINET, André. Évolution des langues et reconstruction. Vendôme: PUF, 1975. (Col. Sup.).

MEILlET, A. Linguistique historique et linguistique générale. Paris: Honoré Champion. 1948. v.1.

MELO, Gladstone Chaves de. Gramática fundamental da lingua portuguesa. 3.ed. Rio de Janeiro: Ao Livro Técnico, 1980.

MELO, Gladstone Chaves de. A lingua do Brasil. [s. 1.]: Lucas/Agir, 1946.

MELO, Lélia Erbolato, MELO, Vilmo Guimarães. Sociolingüística ou sociologia da linguagem? In: CONGRESSO NACIONAL DE SOCIO- E ETNOLINGÜÍSTICA, 2, 1980, Niterói. Comunicações... Niterói: UFF, 28 jul./02 ago. 1980.

MENDONÇA, Renato. A influência africana no português do Brasil. Rio de Janeiro: Civilização Brasileira/INL, 1973. (Retrato do Brasil, 83).

MENDONÇA, Renato. O negro e a cultura no Brasil; breve histórico dos estudos afro-brasileiros de lingüística, etnografia e sociologia. In: HERSKOVITS, Melville J. et al. O negro no Brasil; trabalhos apresentados ao $2^{\circ}$ Congresso Afro-Brasileiro (Bahia). Rio de Janeiro: Civilização Brasileira, 1940. p.99125. (Biblioteca de divulgação científica, 20).

NASCIMENTO, Abdias do. O quilombismo; documentos de uma militância pan-africanista. Petrópolis: Vozes, 1980.

OLIVEIRA, Waldir Freitas. Desenvolvimento dos estudos africanistas no Brasil. Cultura, Brasília: MEC, v.6, n.23, p.110-117, out./dez. 1976.

ORMOND, Jorge Costa. Bom Despacho. Lucas, IBGE, 1970. (Coleção de Monografias, Série B, 164).

PEIXOTO, Antônio da Costa. Obra nova de lingua geral de mina; Publ. e apres. Luís Silveira. Com. Fil. Edmundo Correia Lopes. Lisboa: Agência Geral das Colônias, 1945. 
PEREIRA, João Baptista Borges. Estudos antropológicos e sociológicos sobre o negro no Brasil. In: HARTMAN, Thebla, COELHO, Vera Penteado (Org.). Contribuição à antropologia em homenagem ao Prof. Egon Schaden. São Paulo: Universidade de São Paulo - Faculdade de Filosofia, Letras e Ciências Humanas, 1981. (Col. Museu Paulista, Série Ensaios, 4).

PEREIRA, João Baptista Borges. A folclorização da cultura negra no Brasil. In: SIMPÓSIO ETNIA E RACISMO, 26-27 fev. 1981, Brasília. Comunicações... Brasília: UNB/ EAFORD, 1981.

PONTES, Eunice. Estrutura do verbo no português coloquial. Petrópolis: Vozes, 1972.

PRETI, Dino. A gíria e outros temas. São Paulo: T.A. Queiroz/ EDUSP, 1984.

PRETI, Dino. Os vocabulários especiais e a gíria: perspectivas sociolingüísticas de seu estudo. In: CONGRESSO NACIONAL DE SOCIO- E ETNOLINGÜÍSTICA, 2, 1980, Niterói. Conferências... Niterói: UFF, 28 jul./02 ago. 1980.

RAIMUNDO, Jacques. O elemento afro-negro na lingua portuguesa. Rio de Janeiro: Renascença, 1933.

RAIMUNDO, Jacques. Sugestões. In: HERSKOVITS, M. J. et al. O negro no Brasil; trabalhos apresentados ao II Congresso Afro-Brasileiro (Bahia). Rio de Janeiro: Civilização Brasileira, 1940. p.359-363. (Biblioteca de Divulgação Científica, 20).

RAMOS, Arthur. Introdução à antropologia brasileira. 3.ed. Rio de Janeiro: Casa do Estudante do Brasil, 1962. v.3. Cap.9: A aculturação negra, p.136-153.

RAMOS, Arthur. As culturas negras no novo mundo. 3.ed. São Paulo/Brasília: Editora Nacional/INL, 1979. (Brasiliana, 249).

RAMOS, Arthur. Nina Rodrigues e os estudos negro-brasileiros. In: HERSKOVITS, Melville J. et al. O negro no Brasil; trabalhos apresentados ao II Congresso Afro-Brasileiro (Bahia). Rio de Janeiro: Civilização Brasileira, 1940. p.337-339. (Biblioteca de Divulgação Científica, 20). 
RODRIGUES, Ada Natal. O dialeto caipira na região de Piracicaba. São Paulo: Ática, 1974. (Col. Ensaios, 5).

RODRIGUES, Aryon Dall'Igna. Levantamento e documentação da realidade lingüística do nordeste urbano e rural. In: SEMINÁRIO DE ESTUDOS SOBRE O NORDESTE, 2, 1975, Salvador. Comunicações... Salvador: ABRALIN/UFBA, 24-27 nov. 1975. (Mimeogr.).

RODRIGUES, Laércio. História de Bom Despacho; origens e formação. Belo Horizonte: Imprensa Oficial, 1968.

RODRIGUES, Nina. Os africanos no Brasil. 4.ed. São Paulo/Brasília: Nacional/INL, 1976. (Brasiliana, 9).

ROSSI, Nelson. Atlas prévio dos falares baianos. [s.1.]: MEC/INL, 1963.

SANTOS, Joel Rufino dos. O que é racismo. 6.ed. São Paulo: Brasiliense, [s.d.]. (Col. Primeiros Passos, 7).

SENNA, Nelson de. Africanismos no Brasil. Revista de Lingua Portuguesa, n.10, p.159-163, mar. 1921.

SENNA, Nelson de. Africanos no Brasil; estudos sobre os negros africanos e influências sobre a linguagem e costumes do povo brasileiro. Belo Horizonte: Of. Gráf. Queiroz Breyner, 1938.

SENNA, Nelson de. Contribuições para a ethnologia brasileira: os negros (elementos de origem africana e seus descendentes). Revista de Lingua Portuguesa, n.22, p.136-149, mar. 1923.

SILVA, Rosa V. M. Aspectos do contacto lingüístico no Brasil. Universitas, Salvador, UFBA, n.24, p.83-95, jan./mar. 1979.

SILVA NETO, Serafim da. Guia para estudos dialetológicos. 2.ed. melh. e ampl. Belém: Conselho Nacional de Pesquisas/ Instituto Nacional de Pesquisas da Amazônia, 1957.

SILVA NETO, Serafim da. Introdução ao estudo da lingua portuguêsa no Brasil. Rio de Janeiro: MES/INL/Departamento de Imprensa Nacional, 1950. 
TODD, Loreto. Pidgins and creoles. London: Routledge/Kegan Paul, 1974. (Language and Society, 1).

TURNER, Victor W. O processo ritual; estrutura e anti-estrutura. Trad. Nancy Campi de Castro. Petrópolis: Vozes, 1974.

VALKHOFF, Marius F. Miscelânea luso-africana. Lisboa: Junta de Investigações Científicas do Ultramar, 1975.

VERNHAGEN, Francisco de Adolfo de. História geral do Brasil. 6.ed. (7.ed. do v.1). São Paulo: Melhoramentos, 1959. v.1. Cap.14: Escravidão de africanos. Perigos ameaçadores, p.222-230.

VENDRYES, J. Le langage; introduction lingüistique à l'histoire. Paris: Albin Michel, 1950.

VOGT, Carlos, FRY, Peter Cafundó: a África no Brasil - língua e sociedade. São Paulo: Companhia das Letras; Campinas: Editora Unicamp, 1996.

VOGT, Carlos, FRY, Peter, GNERRE, Maurizio. Las lenguas secretas de Cafundó. Punto de vista, v.9, n.3, p.26-32, 1980.

VOGT, Carlos, FRY, Peter, GNERRE, Maurizio. Cafundó: uma comunidade negra que fala até hoje uma língua de origem africana. Estudos Lingüisticos, Bauru, Faculdade de Filosofia, Ciências e Letras do Sagrado Coração de Jesus de Bauru, n.2, p.11-19, 1978.

WIESEMANN, Ursula, MATTOS, Rinaldo de. Metodologia de análise gramatical. Petrópolis: Vozes, 1980. (Col. Perspectivas Lingüísticas, 17).

YAI, Olabiyi Babalola. Aspectos particulares da influência de culturas nigerianas no Brasil em literatura, folclore e linguagem. Cultura, Brasília, MEC, v.23, n.6, p.94-100, out./ dez. 1976. 
DIRETORA DA COLECÃO

Heloísa Maria Murgel Starling

1. DO SÓTÃO À VITRINE, memórias de mulheres MARIA JOSÉ MOTTA VIANA

2. A IDÉIA DE JUSTIÇA EM KANT, seu fundamento na liberdade e na igualdade - JOAQUIM CARLOS SALGADO

3. ELEMENTOS DE TEORIA GERAL DO DIREITO EDGAR DA MATA MACHADO

4. O ARTESÃO DA MEMÓRIA NO VALE DO JEQUITINHONHA VERA LÚCIA FELÍCIO PEREIRA

5. OS CINCO PARADOXOS DA MODERNIDADE ANTOINE COMPAGNON

6. LIÇÕES DE ALMANAQUE, um estudo semiótico - VERA CASA NOVA

7. MÚLTIPLOS OLHARES SOBRE EDUCAÇÃO E CULTURA JUAREZ DAYRELL (ORG.)

8. ANTROPOLOGIA DA VIAGEM, escravos e libertos em Minas Gerais no século XIX - ILKA BOAVENTURA LEITE

9. O TRABALHO DA CITAÇÃO - ANTOINE COMPAGNON

10. IMAGENS DA MEMÓRIA, entre o legível e o visível CÉSAR GUIMARÃES

11. AO LADO ESQUERDO DO PAI - SABRINA SEDLMAYER

12. NAVEGAR É PRECISO, VIVER: escritos para Silviano Santiago ENEIDA MARIA DE SOUZA e WANDER MELO MIRANDA (ORG.)

13. ADORNOS: nove ensaios sobre o filósofo frankfurtiano RODRIGO DUARTE

14. A ONTOLOGIA DA REALIDADE - HUMBERTO MATURANA

15. VÍSCERAS DA MEMÓRIA, uma leitura da obra de Pedro NavaANTÔNIO SÉRGIO BUENO

16. NA TESSITURA DA CENA, A VIDA: comunicação, sociabilidade e politica MARIA CÉRES PIMENTA SPÍNOLA CASTRO

17. NAVEGANTES DA INTEGRAÇ̃OO, os remeiros do rio São Francisco ZANONI NEVES

18. PÉ PRETO NO BARRO BRANCO, a lingua dos negros da TabatingaSÔNIA QUEIROZ 
Esta edição, em meio digital, é uma edição facsimilar, revista pela autora e por Olívia de Almeida e Editoração eletrônica por Rômulo Costa Vianna. A primeira edição foi composta pela Editora UFMG, em caracteres Gatineau, corpo 11/13, e impressa pela Hamburg Gráfica Editora, em sistema offset, papel offset $90 \mathrm{~g}$ (miolo) e cartão supremo 250g (capa), em junho de 1998. 